\title{
Hydrology and Ground-Water Budgets of the Dayton Valley Hydrographic Area, West-Central Nevada
}

\author{
By Douglas K. Maurer
}

U.S. GEOLOGICAL SURVEY

Water-Resources Investigations Report 97-4123

Prepared in cooperation with the

CARSON WATER SUBCONSERVANCY DISTRICT

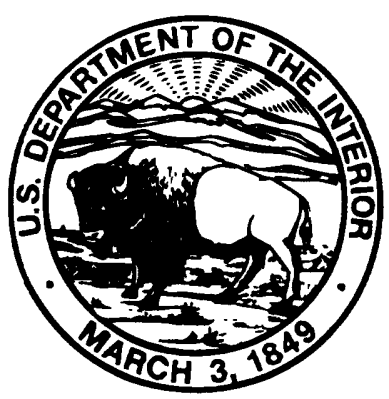

Carson City, Nevada 1997 


\title{
U.S. DEPARTMENT OF THE INTERIOR BRUCE BABBITT, Secretary
}

\author{
U.S. GEOLOGICAL SURVEY \\ GORDON P. EATON, Director
}

Any use of trade names in this publication is for descriptive purposes

only and does not constitute endorsement by the U.S. Government

For additional information write to:

District Chief

U.S. Geological Survey

333 West Nye Lane, Room 203

Carson City, NV 89706-0866

email: usgsinfo_nv@usgs.gov

http://wwwnv.wr.usgs.gov
Copies of this report can be purchased from:

U.S. Geological Survey

Branch of Information Services

Box 25286

Denver, CO 80225-0286 


\section{CONTENTS}

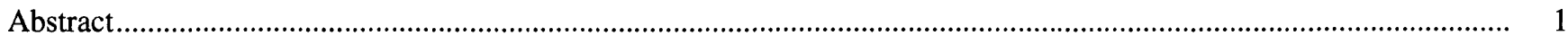

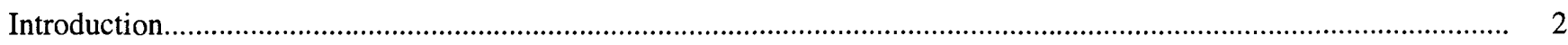

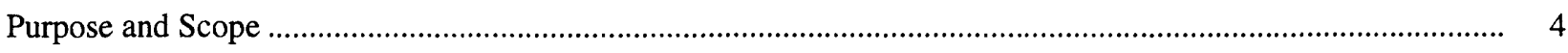

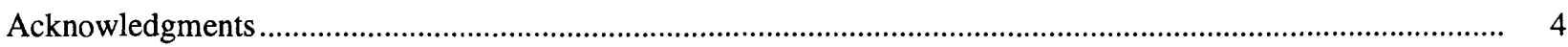

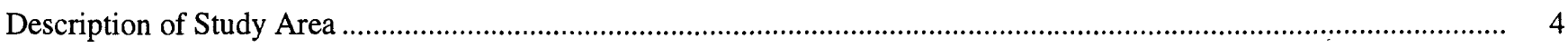

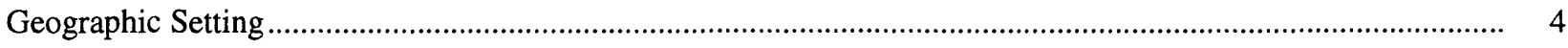

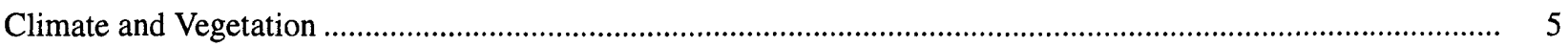

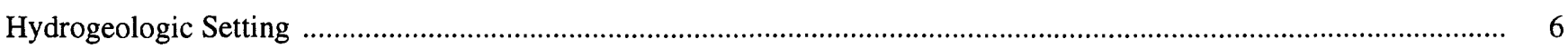

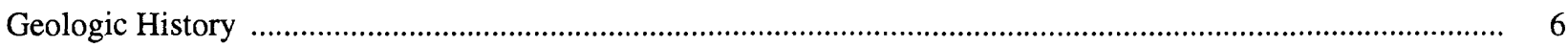

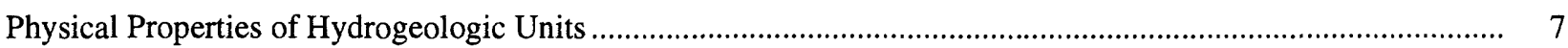

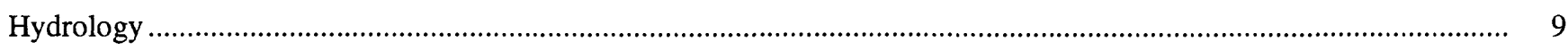

Estimates of Annual Precipitation ...................................................................................................... 9

Altitude-Precipitation Relation of Glancy and Katzer (1976) ..................................................................

Distance-Altitude Relation ............................................................................................................ 10

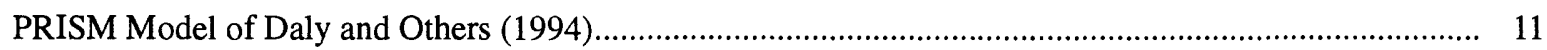

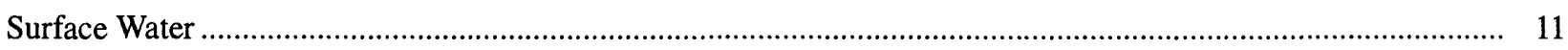

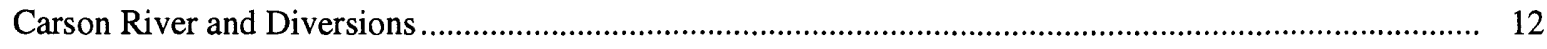

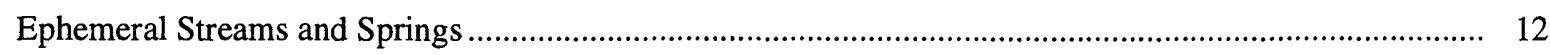

Estimated Gains and Losses for the Carson River ....................................................................... 13

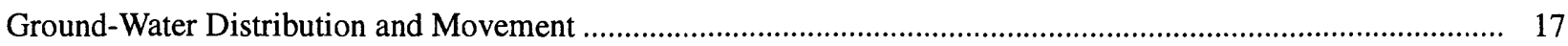

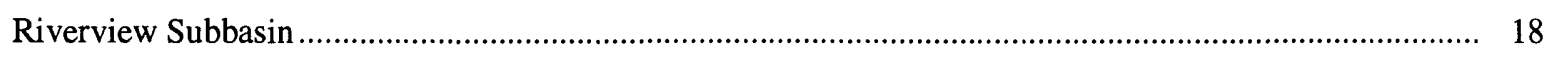

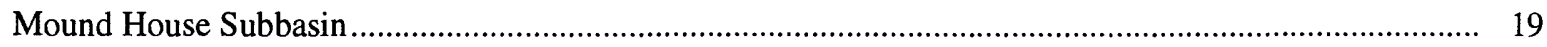

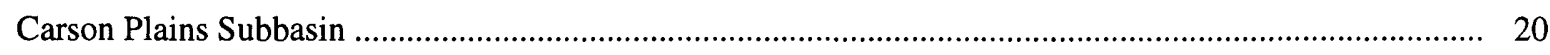

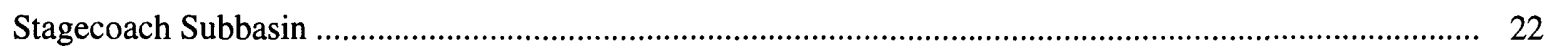

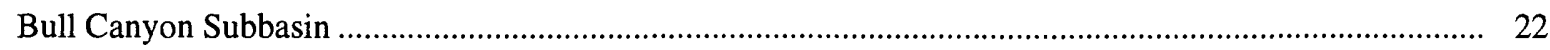

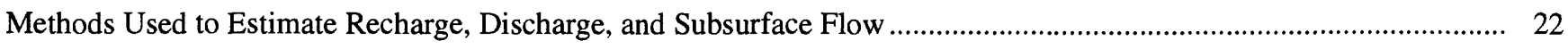

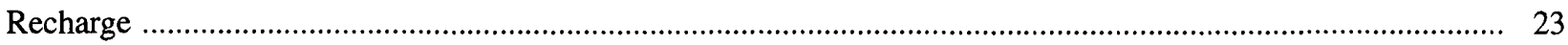

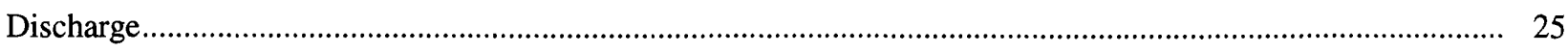

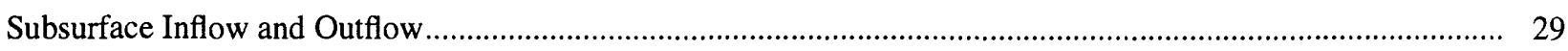

Estimated Water Budgets For Subbasins and for Dayton Valley Hydrographic Area.............................................. 32

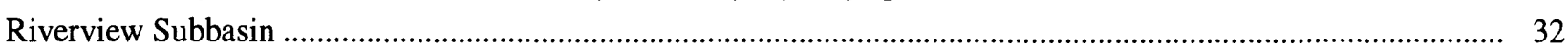

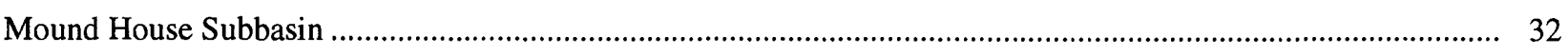

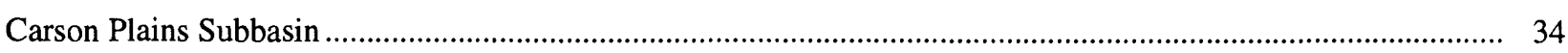

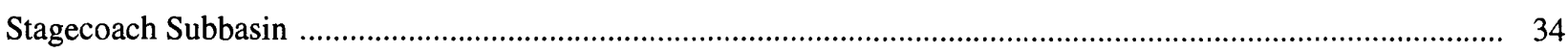

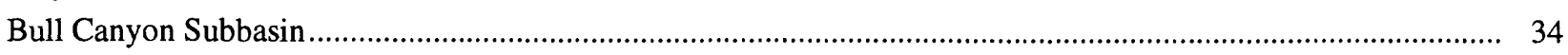

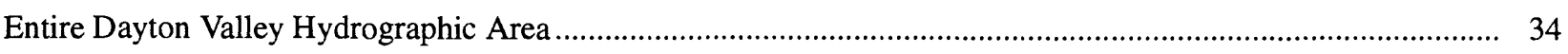

Possible Future Refinement of Estimated Water Budgets ......................................................................... 36

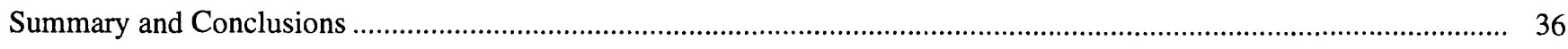

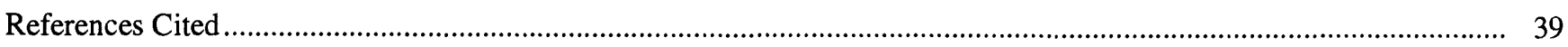

Appendixes

1. Ground-water recharge estimated from precipitation-altitude relations for subbasins of Dayton Valley

Hydrographic Area, Nevada

2. Water levels and other information for wells, Dayton Valley Hydrographic Area, Nevada, 1970-95 ..................... 47 


\section{PLATES}

[In pocket at back of report]

1-3. Maps showing:

1. Areas of irrigated land, phreatophytes, and development, and location of municipal supply wells and discharge of treated effluent in Dayton Valley Hydrographic Area, west-central Nevada

2. Generalized geology of Dayton Valley Hydrographic Area and adjacent areas and hydrogeologic section between Eagle Valley and Riverview subbasin, west-central Nevada

3. Water levels and water-level change for selected wells, 1981-95, and direction of ground-water flow in Dayton Valley and eastern Eagle Valley Hydrographic Areas, west-central Nevada

\section{FIGURES}

1. Map showing location and major geographic features of Dayton Valley Hydrographic Area and subbasins, west-central Nevada, and location of precipitation stations

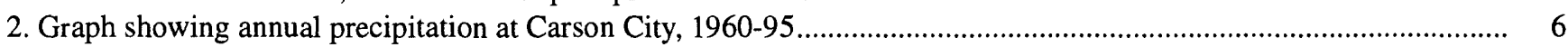

3. Hydrographs showing historical water-level fluctuations in selected wells in Carson Plains subbasin and

Stagecoach subbasin

\section{TABLES}

1. Data for precipitation stations in and near Dayton Valley Hydrographic Area used to develop relation between mean annual precipitation, altitude, and distance from Sierra Nevada crest...

2. Mean annual precipitation from three different relations for distribution of precipitation.......................................... 10

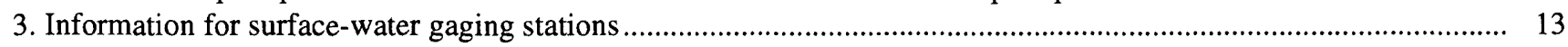

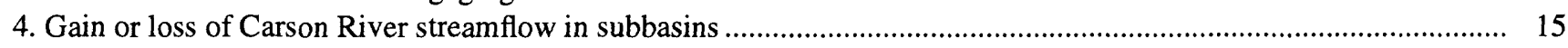

5. Vertical difference in altitude and hydraulic gradients measured between ground-water level and river stage............ 16

6. Estimated recharge for study area using three different precipitation distributions ................................................ 24

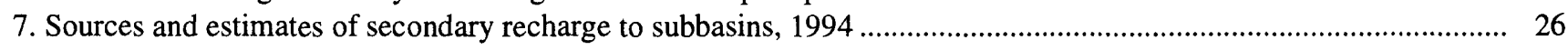

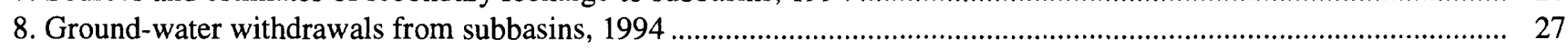

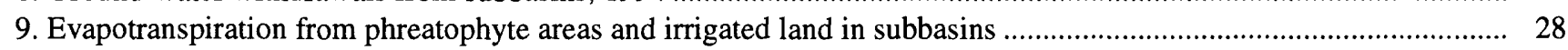

10. Estimates of transmissivity and hydraulic conductivity for selected wells near hydrogeologic section $A-A^{\prime}$, along western boundary of Riverview subbasin using data reported on drillers' logs and other reported values....... 30

11. Estimated subsurface flow from Eagle Valley to Dayton Valley Hydrographic Area .............................................. 31

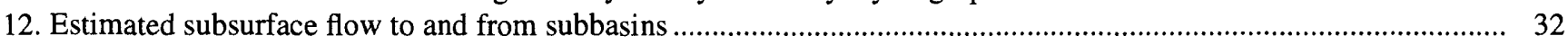

13. Estimates of ground-water inflow and outflow for subbasins and entire Dayton Valley Hydrographic Area............... 33 


\begin{tabular}{rcl}
\hline Multiply & By & To obtain \\
\hline acre & 4,047 & square meter \\
acre-foot (acre-ft) & 1,233 & cubic meter \\
cubic meter per year \\
acre-foot per year (acre-ft/yr) & 1,233 & cubic meter per second \\
cubic foot per second $\left(\mathrm{ft}^{3} / \mathrm{s}\right)$ & 0.02832 & meter \\
foot $(\mathrm{ft})$ & 0.3048 & meter per day \\
foot per day $(\mathrm{ft} / \mathrm{d})$ & 0.3048 & meter per meter \\
foot per foot $(\mathrm{ft} / \mathrm{ft})$ & 1.000 & meter squared per day \\
foot squared per day $\left(\mathrm{ft}^{2} / \mathrm{d}\right)$ & 0.09290 & liter per second per meter \\
gallon per minute per foot $(\mathrm{gal} / \mathrm{min}) / \mathrm{ft}]$ & 0.2070 & millimeter \\
inch (in.) & 25.4 & millimeter per year \\
inch per year (in/yr) & 25.4 & kilometer \\
mile $(\mathrm{mi})$ & 1.609 & square kilometer \\
square mile $\left(\mathrm{mi}{ }^{2}\right)$ & 2.590 &
\end{tabular}

Temperature: Degrees Celsius $\left({ }^{\circ} \mathrm{C}\right)$ can be converted to degrees Fahrenheit $\left({ }^{\circ} \mathrm{F}\right)$ by using the formula ${ }^{\circ} \mathrm{F}=\left[1.8\left({ }^{\circ} \mathrm{C}\right)\right]+32$. Degrees Fahrenheit can be converted to degrees Celsius by using the formula ${ }^{\circ} \mathrm{C}=0.556\left({ }^{\circ} \mathrm{F}-32\right)$.

Sea level: In this report, "sea level" refers to the National Geodetic Vertical Datum of 1929 (NGVD of 1929, formerly called "Sea-Level Datum of 1929"), which is derived from a general adjustment of the first-order leveling networks of the United States and Canada. 


\title{
Hydrology and Ground-Water Budgets of the Dayton Valley Hydrographic Area, West-Central Nevada
}

\author{
By Douglas K. Maurer
}

\section{ABSTRACT}

Increasing development in the Dayton Valley Hydrographic Area, east of Carson City, Nevada, has caused concerns over the available ground-water supply. In 1994, a study began to assess ground water in subbasins of the area. The hydrographic area is about 10 miles east of the Sierra Nevada, and the Carson River flows from west to east through the area. The hydrographic area was divided into five subbasins for which ground-water budgets were estimated. The subbasins, from west to east, are: Riverview, Mound House, Carson Plains, Stagecoach, and Bull Canyon. Ground-water levels were measured and lines of equal water-level attitude were developed for the three westernmost subbasins.

Three estimates of the distribution of mean annual precipitation in the hydrographic area and in each subbasin were obtained using a previously published relation between annual precipitation and altitude; a relation developed for this study between annual precipitation, altitude, and distance from the Sierra crest; and a precipitation map for Nevada produced in 1996. Estimates of total annual precipitation are 180,000 acre- $\mathrm{ft}$ (acre-feet) using the first distribution, 200,000 acre-ft using the second, and 250,000 acre-ft using the third. Both the second and third distributions estimate more precipitation at higher altitudes than the previously published relation.

The ground-water budgets include estimates of inflow to ground water from (1) infiltration of precipitation and streamflow generated within the area; (2) infiltration of streamflow along the
Carson River; (3) infiltration of ground water pumped for municipal, domestic, and agricultural purposes; and (4) subsurface flow from the adjacent Eagle and Carson Valley Hydrographic Areas and between the subbasins. The ground-water budgets also include estimates of outflow from ground water to (1) evapotranspiration and crop consumptive use; (2) seepage to the Carson River; (3) ground-water pumpage for municipal, domestic, and agricultural purposes; and (4) subsurface flow to the adjacent Churchill Valley Hydrographic Area and between subbasins.

Estimates of recharge from infiltration of precipitation and streamflow generated within each subbasin were made by applying the MaxeyEakin method to the three distributions of mean annual precipitation. The resulting estimates are $7,800,11,000$, and 26,000 acre-ft/yr (acre-feet per year), showing that recharge calculated using the Maxey-Eakin method is greatly dependent on the distribution of mean annual precipitation. Thus, three values are used to report total inflow to ground water in the study area.

Estimates of ground-water inflow to the Riverview subbasin are 5,600,5,800, and 6,900 acre-ft/yr, and estimated ground-water outflow is slightly larger, 6,600-8,400 acre-ft/yr. Estimates of inflow to the Mound House subbasin are 3,300, 3,700 , and 5,600 acre-ft/yr, whereas estimates of outflow are much less, $600-800 \mathrm{acre}-\mathrm{ft} / \mathrm{yr}$. Outflow from the subbasin beneath the channel of the Carson River to the Carson Plains subbasin could be greater than estimated. Estimates of inflow to the Carson Plains subbasin are 7,000, 8,700, and $18,000 \mathrm{acre}-\mathrm{ft} / \mathrm{yr}$, and estimates of outflow are 
9,300-13,000 acre-ft/yr. The apparent imbalance would be reduced if subsurface inflow from the Mound House sub-basin is greater than estimated. Also, possible water-level declines could cause a decrease of 200-300 acre-ft/yr in ground-water storage. Estimates of inflow to the Stagecoach subbasin are 1,300,1,500, and 2,200 acre-ft/yr, and estimates of outflow total 1,800 acre-ft/yr, with a decrease in ground-water storage of about $450 \mathrm{acre}-\mathrm{ft} / \mathrm{yr}$. Estimates of inflow to the Bull Canyon subbasin are 3,600, 3,800, and 6,100 acre-ft/yr, whereas estimates of outflow are 2,100-3,400 acre-ft/yr. Uncertainties in estimates for recharge and discharge could also contribute to the apparent imbalances in water budgets for the individual subbasins.

Total estimated inflow to ground water in the Dayton Valley Hydrographic Area is 19,000 , 23,000 , and $37,000 \mathrm{acre}-\mathrm{ft} / \mathrm{yr}$. These include $7,800,11,000$, and 26,000 acre-ft/yr from infiltration of precipitation and streamflow generated within the area; 7,000 acre-ft/yr from stream losses of the Carson River, 2,300-2,900 acre-ft/yr of secondary recharge of pumped water, and 2,200 acre-ft/yr of subsurface flow from Eagle Valley. Estimates of outflow from ground water are 19,000-26,000 acre-ft/yr. These include 10,000 acre- $\mathrm{ft} / \mathrm{yr}$ of ground-water pumpage, 7,300$13,000 \mathrm{acre}-\mathrm{ft} / \mathrm{yr}$ discharged by crops, 1,100 3,000 acre-ft/yr discharged by phreatophytes, and $230 \mathrm{acre}-\mathrm{ft} / \mathrm{yr}$ of subsurface outflow to Churchill Valley.

The low-range and mid-range estimates of ground-water inflow are similar to the range in estimates of outflow. In contrast, the high-range estimate of inflow is more than $10,000 \mathrm{acre}-\mathrm{ft} / \mathrm{yr}$ greater than estimated outflow. This implies that estimates of recharge using the precipitation map for Nevada produced in 1996 could be too high.

The net inflow and outflow of 17,000 acre$\mathrm{ft} / \mathrm{yr}$ estimated in 1976 for Dayton Valley is similar to the low-range estimate developed in this study, and is about half of the high-range estimate. The previous estimate used a single value for discharge by ground-water pumping, crop consumptive use, and evapotranspiration that was calculated by difference, to balance inflow and outflow. Also, recharge from streamflow generated within the area and from precipitation could be greater than previously estimated.

\section{INTRODUCTION}

Increasing development in the Dayton Valley Hydrographic Area, ${ }^{1}$ east of Carson City, Nev., has caused concerns over the available ground-water supply (fig. 1). The water budget for the area was last assessed in the early 1970's as part of a ground-water reconnaissance study of the entire Carson River Basin (Glancy and Katzer, 1976). Changes in development since the reconnaissance study could have affected the water budget of the area. The population of the area has increased from about 650 in 1971 (Glancy and Katzer, 1976, p. 56) to over 4,000 in 1990 (Lyon County Master Plan, 1990, p. 30), increasing water use and possibly affecting the distribution of ground-water recharge and discharge. The reconnaissance study estimated ground-water inflow from Eagle Valley to aquifers on the western side of the Dayton Valley Hydrographic Area. Increased ground-water withdrawals in Eagle Valley could have changed the volume of ground-water flow between the two hydrographic areas.

The Carson River, which flows through the area, is hydraulically connected with aquifers that supply ground water for municipal, domestic, and agricultural use. Flow of the Carson River could change in response to changes in water use in Carson Valley, upstream from Dayton Valley (Prudic and Wood, 1995, p. 12). Also, development in Dayton Valley could affect downstream river flow, which is becoming increasingly important to downstream water users.

The population of the Dayton Valley Hydrographic Area is expected to increase at an even greater rate in the future, especially in the western part of the area. Prior to 1994, water-level data from the western part of the area were sparse. Such data would provide a greater understanding of the hydrogeologic setting

\footnotetext{
${ }^{1}$ Formal hydrographic areas in Nevada were delineated systematically by the U.S. Geological Survey and Nevada Division of Water Resources in the late 1960's (Rush, 1968; Cardinalli and others, 1968) for scientific and administrative purposes. The official hydrographic-area names, numbers, and geographic boundaries continue to be used in Geological Survey scientific reports and Division of Water Resources administrative activities.
} 


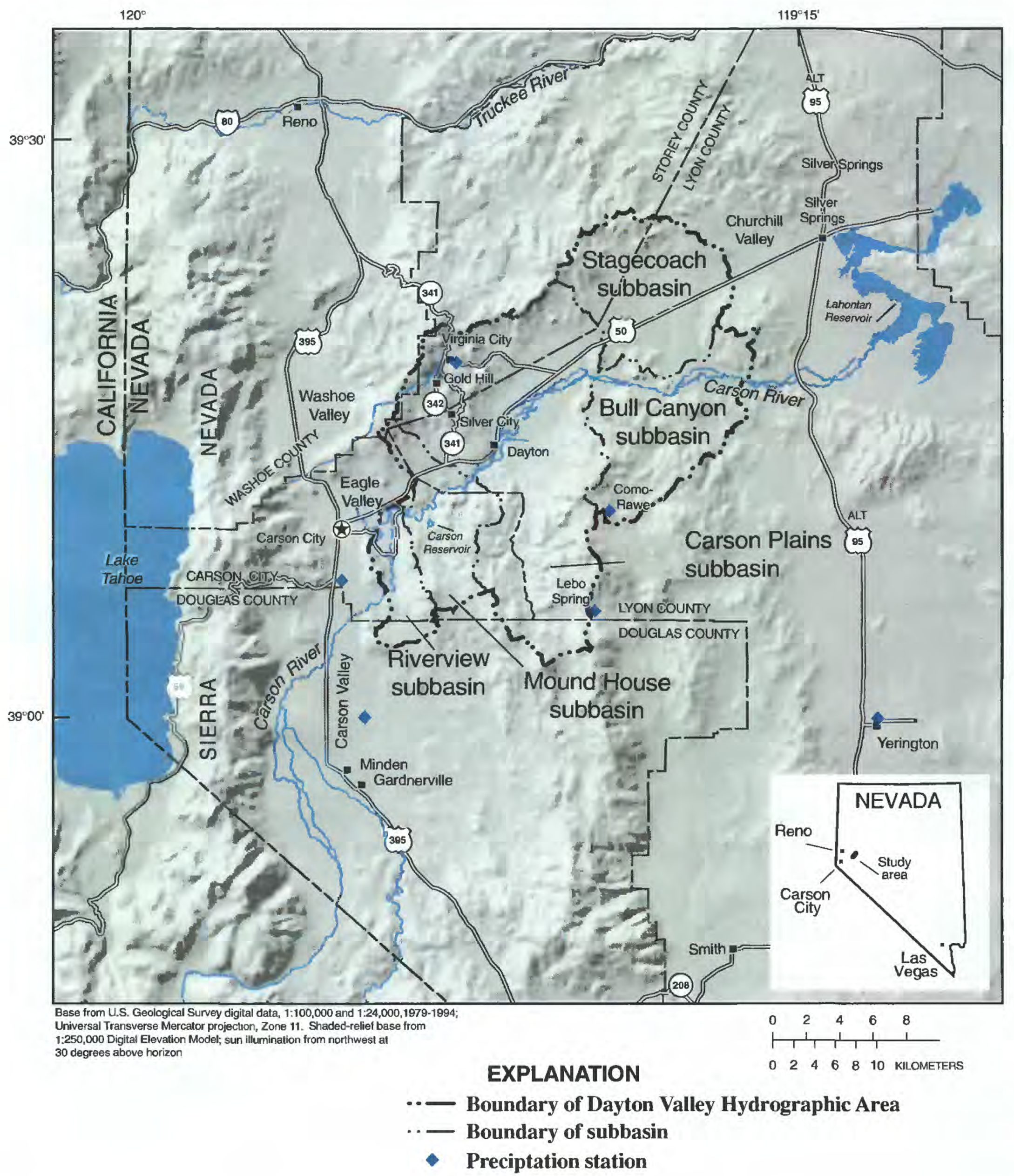

Figure 1. Location and major geographic features of Dayton Valley Hydrographic Area and subbasins, west-central Nevada, and location of precipitation stations. See table 1 for precipitation information. 
and a data base with which to assess the effects of continued development. A reassessment of water budgets would allow more effective planning for development and more efficient management of the regional water resources. In 1994, the U.S. Geological Survey, in cooperation with the Carson Water Subconservancy District, began a study of water resources in the Dayton Valley Hydrographic Area.

\section{Purpose and Scope}

This report describes results of an initial phase of work on subbasins of the Dayton Valley Hydrographic Area. The purpose of the initial phase was to update the hydrologic data base for the three western subbasins, describe the hydrogeologic setting of the three western subbasins and the entire area, reassess key waterbudget elements, update and refine the reconnaissance water budget developed in the early 1970's for the hydrographic area, develop water budgets for the individual subbasins, and determine additional work needed to refine water-budget elements.

This report describes the Dayton Valley Hydrographic Area in terms of geography, climate and vegetation, geology, and hydrology, and presents a ground-water budget for the entire area and for the five subbasins (pl. 1). The subbasins from west to east are: Riverview, Mound House, Carson Plains, Stagecoach, and Bull Canyon. Descriptions of hydrology are based on water-level measurements made at 106 wells in 1994 and 1995 in and near the three western subbasins, a study by Harrill and Preissler (1994) in the Stagecoach and Bull Canyon subbasins, and historical hydrologic data in U.S. Geological Survey data bases. Ground-water budgets are based on data collected in 1994.

The ground-water budgets include estimates of inflow to ground water from (1) infiltration of streamflow generated within the area and precipitation;

(2) infiltration of streamflow of the Carson River;

(3) infiltration of ground water pumped for municipal, domestic, and agricultural purposes; and (4) subsurface flow from the adjacent Eagle and Carson Valley Hydrographic Areas and between the subbasins (pl. 1). The ground-water budget also includes estimates of outflow from ground water by (1) evapotranspiration and crop consumptive use; (2) seepage to the Carson River; (3) pumping for municipal, domestic, and agricultural purposes; and (4) subsurface flow to the adjacent
Churchill Valley Hydrographic Area and between subbasins. Methods to refine estimates of waterbudget components are also discussed.

\section{Acknowledgments}

The study documented in this report was made in cooperation with the Carson Water Subconservancy District. The author thanks, first and foremost, the private well owners who allowed access for water-level measurements without which this study could not have been completed. Dorothy Timian-Palmer of the Carson City Utilities Department and Don Allen of Dayton Utilities provided valuable data on current groundwater use in the study area.

\section{DESCRIPTION OF STUDY AREA}

\section{Geographic Setting}

The Dayton Valley Hydrographic Area includes about $360 \mathrm{mi}^{2}$ and lies just east of Carson City, the capital of Nevada (fig. 1). The hydrographic area is rapidly becoming a bedroom community for the capital, and the westernmost part of the area is located within the Carson City urban limits.

The Dayton Valley Hydrographic Area is bounded on the south by the Pine Nut Mountains, which rise to altitudes of over $8,000 \mathrm{ft}$ above sea level, and on the north by the Virginia Range and the Flowery Range, which rise to slightly less than $8,000 \mathrm{ft}$ and about $7,000 \mathrm{ft}$, respectively (pl. 1). The area is bounded on the west by Eagle Valley, on the south by Carson Valley, and on the east by Churchill Valley (fig. 1).

The Carson River originates on the eastern slope of the Sierra Nevada and flows from west to east through the Dayton Valley Hydrographic Area (fig. 1) with an average discharge of about 284,000 acre- $\mathrm{ft} / \mathrm{yr}$ near Carson City (Clary and others, 1995, p. 206). In Carson Valley upstream from the Dayton Valley Hydrographic Area, the river is diverted in many places for flood irrigation of alfalfa and pasture lands. Downstream from the area, the river enters Lahontan Reservoir where flow is stored for irrigation of lands to the east. The altitude of the river drops about $400 \mathrm{ft}$ over a distance of about $30 \mathrm{mi}$ across the Dayton Valley Hydrographic Area, from an altitude of $4,600 \mathrm{ft}$ near Carson City to $4,200 \mathrm{ft}$ near the eastern side of the area. 
For this study, the hydrographic area was divided into subbasins using topographic divides (fig. 1). One exception to this is the hydrographic area boundary determined by Rush (1968) between the Eagle Valley Hydrographic Area and the Riverview subbasin, where streamflow of Eagle Valley creek (locally named) and three other small streams from the northern part of Eagle Valley cross the boundary.

The Riverview subbasin is separated from Eagle Valley Hydrographic Area by Prison Hill and small, isolated hills north of Prison Hill. Flow of the Carson River is diverted through Mexican Ditch for crop and pasture irrigation west of the river (pl. 1). The valley floor of the subbasin lies at an altitude of about 4,600 $\mathrm{ft}$. Residential developments are along both sides of the river, and light industrial development is on the northwestern side (pl. 1).

West of the river in the Riverview subbasin, water and sewer service is supplied by the Carson City Utilities Department to most residents. East of the river, all residents have individual domestic wells and septic systems. Ground water in this area is affected by a geothermal source, which makes the water nonpotable at many locations (Trexler and others, 1980, p. 23). West and south of the point where the Carson River turns eastward, treated effluent has been used to irrigate crops on about 200 acres of land (pl. 1). This land has recently (1995) been converted to a golf course that will also receive treated effluent for irrigation. Just north of the subbasin boundary, the Eagle Valley Golf Course and recreation facilities cover about 270 acres, which are irrigated with treated effluent (pl. 1).

The Carson River has eroded a deep canyon through the Mound House subbasin, south of the main valley floor. The main valley floor is higher than the adjacent subbasins at an altitude of about $4,800 \mathrm{ft}-200 \mathrm{ft}$ higher than the floor of the Riverview subbasin and $500 \mathrm{ft}$ higher than the floor of the Carson Plains subbasin. Residential and industrial development are taking place only north of the river. South of the river, the subbasin is mountainous with no development except for a reservoir used to store effluent from Carson City (pl. 1). Water and sewer service is supplied to many residents by Dayton Utilities except south of the intersection of U.S. Highway 50 and Nevada Highway 341 (pl.1). Some industrial and minor residential development along the northeastern part of the subbasin is actually north of the topographic divide between the Mound House and Carson Plains subbasins (pl. 1). Ground water in large parts of the Mound House subbasin is of poor quality, probably caused by localized gypsite deposits (Glancy and Katzer, 1976, p. 88). For this reason, many municipal wells that supply water to the Mound House subbasin are in the northwestern part of the Carson Plains subbasin.

The Carson River emerges from the canyon and enters the Carson Plains subbasin about 2 mi southwest of the town of Dayton. The historic Comstock Lode mining district was located near Virginia City, Gold Hill, and Silver City in the Virginia Range north of Dayton. These three towns use water imported from the Carson Range through a pipeline, known as the Virginia City siphon, that was installed near the turn of the century and is still in use today (Shamberger, 1972). On the floor of the subbasin, numerous diversions from the Carson River irrigate crops on lands adjacent to the river (diversions shown on pl. 2). Residential development is increasing across much of the valley floor of the subbasin (pl. 1). Dayton Utilities supplies water and sewer service for most residents near the western margin of the Carson Plains subbasin; however, individual domestic wells and septic tanks are used in the eastern part of the subbasin.

The Stagecoach subbasin is topographically closed and is north of the Carson River. The valley floor is at an altitude of about 4,280 ft. As of 1994 , ground water is pumped for irrigation of about 300 acres, and the Stagecoach General Improvement District supplies water for part of the residential development. The remainder of the population is served by individual domestic wells. All residents use septic systems.

The Bull Canyon subbasin is isolated and mountainous. Development is sparse, except for crop irrigation, which uses diversions from the Carson River on lands adjacent to the river.

\section{Climate and Vegetation}

The study area lies in the rain shadow of the Sierra Nevada and, as a result, has an arid to semiarid climate. Winter storms approaching from the west produce rain and snow as the bulk of the annual precipitation. Lesser amounts of precipitation come during summer months from intense, localized thunderstorms.

Annual precipitation recorded at weather stations in and near the study area varies from about 5 in. at Lahontan Dam to about 14 in. at Virginia City (table 1; fig. 1). Estimates of the precipitation that falls on the Dayton Valley Hydrographic Area are discussed in the section "Hydrology" of this report. From about 1987 to 
Table 1. Data for precipitation stations in and near Dayton Valley Hydrographic Area, Nevada, used to develop relation between mean annual precipitation, altitude, and distance from Sierra Nevada crest

\begin{tabular}{lcccc}
\hline \multicolumn{1}{c}{$\begin{array}{c}\text { Station } \\
\text { (fig. 1) }\end{array}$} & $\begin{array}{c}\text { Altitude } \\
\text { (feet } \\
\text { above } \\
\text { sea } \\
\text { level) }\end{array}$ & $\begin{array}{c}\text { Distance } \\
\text { from } \\
\text { Slerra } \\
\text { crest } \\
\text { (miles) }\end{array}$ & $\begin{array}{c}\text { Mean } \\
\text { annual } \\
\text { precipitation, } \\
\mathbf{1 9 6 1 - 9 0} \\
\text { (inches) }\end{array}$ & $\begin{array}{c}\text { Mean } \\
\text { annual } \\
\text { precipitation, } \\
1969-94 \\
\text { (inches) }\end{array}$ \\
\hline Yerington & 4,380 & 44.9 & ${ }^{1} 5.52$ & 5.08 \\
Lahontan Dam & 4,150 & 50.1 & ${ }^{1} 5.43$ & 5.10 \\
Minden & 4,709 & 13.6 & ${ }^{1} 8.13$ & 7.75 \\
Carson City & 4,651 & 12.6 & ${ }^{1} 10.87$ & 9.98 \\
Virginia City & 6,340 & 19.9 & ${ }^{1} 13.86$ & 14.33 \\
Como-Rawe & 7,200 & 35.0 & ${ }^{2} 15.44$ & 315.44 \\
Lebo Spring & 7,000 & 30.5 & ${ }^{2} 15.72$ & 315.72 \\
\hline
\end{tabular}

\footnotetext{
${ }^{1}$ Owenby and Ezell (1992).

${ }^{2}$ Estimated by James (1995).

${ }^{3}$ Assumed to be approximately equal to mean for 1961-90.
}

1994, western Nevada was affected by a long-term drought, and annual precipitation was below normal (fig. 2). In 1995, precipitation was well above normal.

Temperatures in the study area vary greatly; such variability is typical of semiarid climates. Summertime temperatures can reach over $100^{\circ} \mathrm{F}$ but normally range from 80 to $90^{\circ} \mathrm{F}$. Low temperatures in winter can fall below $0^{\circ} \mathrm{F}$. Low relative humidity allows large diurnal temperature variations of as much as $40^{\circ} \mathrm{F}$ in both

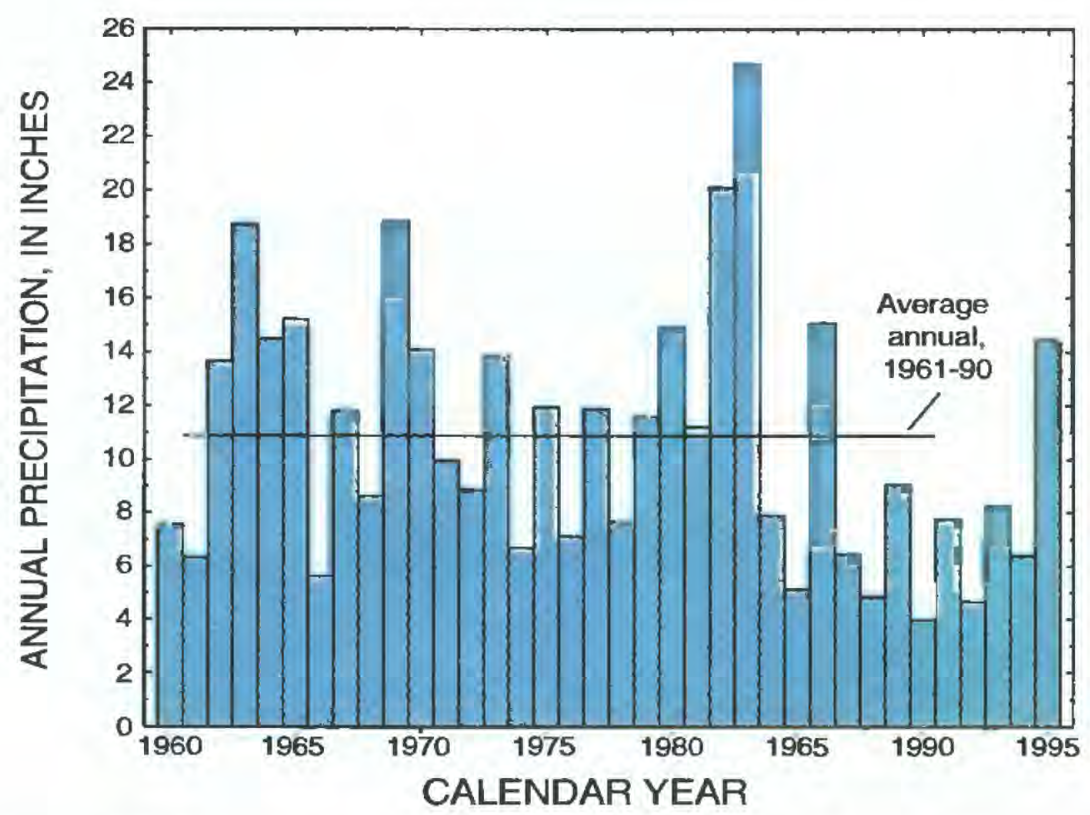

Figure 2. Annual precipitation at Carson City, Nevada, 1960-95. Annual average precipitation from Owenby and Ezell, 1992. summer and winter months. The average annual growing season is about 120 days (Harrill and Preissler, 1994, p. 48).

Vegetation in the study area consists of pinon pine and juniper in the mountains, and the valley floors are sparsely covered with sage, rabbitbrush, and greasewood. Native grasses, cottonwood, and willow are found along the channel of the Carson River. Greasewood, rabbitbrush, native grasses, willow, and cottonwood are phreatophytes, which can derive part of their water from the water table.

\section{HYDROGEOLOGIC SETTING}

The geologic setting greatly affects the hydrology of the study area by controlling the movement of water in the subsurface. Ground water is found in both consolidated rocks and unconsolidated and partly consolidated sediments. In consolidated rocks, the rock type and degree of weathering and fracturing affect the rate and direction of ground-water flow. In sediments, ground-water flow is affected by the grain size and the degree of sorting, consolidation, and cementation. The distribution of consolidated rocks and sediments and their physical properties is the result of the geologic processes that have taken place in and upgradient from the study area.

\section{Geologic History}

About 90 million years ago, in what is now the Dayton Valley area, volcanic and sedimentary rocks of Triassic to Jurassic age (about 240 to 140 million years old) were intruded and metamorphosed by granitic plutons of the Sierra Nevada batholith (Bonham, 1969, p. 9). These rocks were tilted and eroded to a surface of low to moderate relief when thick sequences of volcanic rocks erupted beginning about 20 million years ago (Bonham, 1969, p. 50 and 25). The granitic and metamorphic rocks are exposed mainly in the Riverview and Mound House subbasins where the overlying volcanic rocks have eroded away (Moore, 1969, p. 16).

About 17 million years ago, faulting, tilting and warping, which produced the present-day topography, began (Stewart, 1980, p. 110; Moore, 1969, p. 16). This deformation uplifted mountain ranges within the study area and downdropped the valley floors. Normal faulting associated with basin-and-range extension produced north-south oriented mountain ranges and 
valleys. This pattern is interrupted between the Virginia Range and the Pine Nut Mountains by a lineament marked by valleys and the ends of mountain ranges and extends over $100 \mathrm{mi}$ from Carson City to the northeast (Bonham, 1969, p. 50; Moore, 1969, p. 18). The lineament is a fault zone with left-lateral offset and is called the Carson Lineament by Rogers (1975). Movement along this feature combined with normal faulting produced northeast-trending valleys in the Mound House, Carson Plains, and Stagecoach Valley subbasins (Shawe, 1965, p. 1373).

Faulting has continued to the present time and was accompanied by continued volcanism, which produced sequences of volcanic rocks as young as 1 million years old (Bonham, 1969, p. 40). As valleys formed, sediments that eroded from the mountain blocks were deposited by the Carson River and perennial streams into the valleys. The oldest of these sediments are probably Pliocene in age (from 5 to 2 million years old) and contain large amounts of volcanic ash (Moore, 1969, p. 12). These sediments became partly consolidated and cemented and, in the Pine Nut Mountains, have been uplifted along with the mountain blocks (pl. 2). More recent, unconsolidated sediments overlie the older sediments in the valleys.

East of Dayton, sediments transported by the Carson River were deposited in an ancient lake called Lake Lahontan, which covered large parts of northern Nevada (Morrison, 1991, p. 287). The lake was present from over 1 million to about 11,000 years ago with several high stands separated by periods when the lake was dry (Morrison, 1991, p. 291, and Benson, 1978, p. 312-315). During high stands, the lake level had an altitude of about $4,380 \mathrm{ft}$, filling the Stagecoach and Carson Plains subbasins to depths of over $100 \mathrm{ft}$ and $40 \mathrm{ft}$, respectively (Moore, 1969, p. 15). As lake leveis rose and fell, the deposition of deltas, beaches, sand dunes, and lake sediments moved back and forth across the area of the Carson Plains, Stagecoach, and Bull Canyon subbasins.

Streamflow of the Carson River has created a flood plain in the Riverview subbasin and, since the last high stand of Lake Lahontan, in the Carson Plains and Bull Canyon subbasins. Runoff from perennial and ephemeral streams has deposited alluvial fans at the base of the mountain blocks and near the mouths of the larger canyons surrounding the valley floors.

\section{Physical Properties of Hydrogeologic Units}

Consolidated rocks form the mountain blocks in the study area and also underlie partly consolidated and unconsolidated sediments that fill the valleys. Hydrogeologic units that form the consolidated rocks are collectively referred to as bedrock, and sedimentary units are referred to as basin-fill sediments.

Consolidated rocks are divided into five hydrogeologic units on plate 2: (1) metamorphic rocks, (2) granitic rocks, (3) rhyolitic volcanic rocks, (4) andesitic volcanic rocks, and (5) basaltic volcanic rocks. Currently, data on the physical properties of consolidated rocks in the study area are sparse. For this reason, the grouping of rock types used in this report is considered to be preliminary. The grouping is based on existing descriptions of the fracturing, weathering, and other physical properties of each group.

Plate 2 was generated from a digital version (J.H. Stewart, written commun., 1987) of geologic mapping at 1:250,000 scale of Carson City, Douglas, and Lyon Counties by Moore (1969), of Storey County by Bonham (1969), and mapping at 1:24,000 scale of the New Empire topographic quadrangle by Bingler (1977). Minor modifications of the original published maps were made near the boundary of the New Empire quadrangle to join hydrogeologic units mapped at different scales. Hydrogeologic units mapped at $1: 250,000$ do not show all existing details. For example, basin-fill sediments are found beneath the Carson River and at distances of 100-300 ft away from the river throughout the Mound House subbasin. However, the geologic map by Moore (1969) and units shown on plate 2 do not distinguish these sediments from the surrounding consolidated rocks.

Metamorphic rocks are closely associated with granitic rocks throughout the study area and are composed of both metasedimentary and metavolcanic rocks. The metamorphic rocks are metasediments on the eastern side of the Riverview subbasin, and are mostly metavolcanic elsewhere in the hydrographic area (Moore, 1969, pl. 1). The metasedimentary rocks include slate, graywacke, quartzite, schist, limestone, and gypsum (Moore, 1969, p. 6). Gypsum and massive anhydrite are associated with these rocks in the northern part of the Mound House subbasin (Archbold, 1969 , p. 34). The metavolcanic rocks are andesitic breccias near Prison Hill and metabasalts along the Carson River canyon in the Mound House subbasin and near the Comstock Lode (Bonham, 1969, p. 6 and 7). Metamorphic rocks in the Pine Nut Mountains 
south of the study area are thousands of feet thick (Bonham, 1969, p. 6); likewise, similar rocks within the study area probably are thousands of feet thick.

West of Carson City, metamorphic rocks were found to be highly fractured to depths of greater than $70 \mathrm{ft}$, and fractures are clay filled at the greatest depths. Metamorphic rocks without clay-filled fractures are highly permeable, with a hydraulic conductivity as great as $30 \mathrm{ft} / \mathrm{d}$. Metamorphic rocks with clay-filled fractures have hydraulic conductivities of about 1-2 ft/d (Maurer and others, 1996, p. 21). Drillers' logs show that wells produce water from metamorphic rocks in the Riverview and Mound House subbasins (pl. 3). The extent and permeability of fractured zones in metamorphic rocks throughout the remainder of the study area are unknown.

The granitic rocks are generally massive intrusions of granodiorite that have low permeability to ground-water flow except where fractured or weathered. West of Carson City, granitic rocks were found to have a weathered zone about $50 \mathrm{ft}$ thick with a hydraulic conductivity of about $1 \mathrm{ft} / \mathrm{d}$ (Maurer and others, 1996, p. 21). Granitic rocks probably underlie other hydrogeologic units throughout the study area because they are exposed at widely scattered locations (pl. 2). Drillers' logs show that near the northern end of the Riverview subbasin, wells produce water from fractured granitic rocks (pl. 3). The extent and permeability of weathered and fractured zones in granitic rock throughout the remainder of the study area are unknown.

Rhyolitic volcanic rocks about 20 million years old are commonly pink-to-purple ash-fall and ash-flow tuffs, tuff-breccias, and welded tuffs (Moore, 1969, p. 10). They are exposed mainly in the Mound House subbasin and near Virginia City where they are as thick as $1,000 \mathrm{ft}$ (Moore, 1969, p. 10). Crude columns developed in the unit during cooling (Moore, 1969, p. 10), and the rocks are probably moderately permeable. Wells in the Mound House subbasin produce water from the unit (pl. 3).

Andesitic volcanic rocks ranging from about 20 to 13 million years old are exposed extensively in the mountain blocks within the Carson Plains and Stagecoach subbasins. The andesitic rocks are heterogeneous in lithology; they actually range in composition from rhyolitic to basaltic, but are mostly andesites (Moore, 1969, p. 11). They are composed of breccias, flow breccias, lava flows, tuffs, and volcanic sandstones and conglomerates. They are oldest near Virginia City where they are about $2,700 \mathrm{ft}$ thick and have been hydrothermally altered (Bonham, 1969, p. 25). Elsewhere in the study area they could be several thousand feet thick (Moore, 1969, p. 11). Where fractured, the andesitic rocks are permeable to ground-water flow, and wells near Gold Hill, Mound House, and Dayton produce water from the unit (pl. 3).

Basaltic volcanic rocks about 1 million years old are exposed along the divide between the Riverview and Mound House subbasins, near the southern part of the Stagecoach subbasin, and extensively in the Bull Canyon subbasin. The rocks are described as fractured and vesicular (Bonham, 1969, p. 40) and probably have high permeability. Thompson (1956, p. 59) estimates that the basaltic rocks do not exceed $50 \mathrm{ft}$ in thickness near the Mound House subbasin; however, about $150 \mathrm{ft}$ of basaltic rock that is probably part of the same unit was penetrated by a municipal well near the northern boundary of the Riverview subbasin (inset, pl. 2). Harrill and Preissler (1994, p. H6) show a thickness of about $500 \mathrm{ft}$ for Quaternary basaltic rocks near the southern end of the Stagecoach Valley subbasin and suggest that the unit transmits water from the Carson River to the Stagecoach subbasin. The thickness of this unit in the Bull Canyon subbasin is unknown.

Basin-fill sediments are exposed on the floor of all subbasins and have been divided into two hydrogeologic units: (1) partly consolidated sediments and (2) unconsolidated sediments.

Partly consolidated sediments 5 to 2 million years old are exposed in the eastern part of the Riverview subbasin, the southern part of the Carson Plains subbasin, and in the Bull Canyon subbasin. They consist of fine-grained lake sediments that have been partly consolidated to mudstone, siltstone, and shale with lenses of sand and gravel. The fine-grained sediments are composed largely of volcanic ash. Because they were deposited during uplift of the mountain ranges, they are exposed in the mountain blocks, and are probably also present beneath unconsolidated sediments covering the valley floors. The thickness of the unit is estimated to be greater than 3,000 ft near Virginia City and greater than 1,000 ft in the Pine Nut Range (Moore, 1969, p. 12). The permeability of the unit as a whole is low; however, water probably is readily transmitted through the lenses of sand and gravel. Some wells in the Riverview subbasin and in neighboring Carson Valley produce small amounts of water from the unit.

Unconsolidated sediments are generally less than 2 million years old and consist of Lake Lahontan sediments and flood-plain, eolian, and alluvial-fan 
sediments deposited before, during, and after the presence of Lake Lahontan. Included in this unit are deposits of apparently small areal extent, called older alluvium by Moore $(1969$, p. 14), that could be more than 5 million years old.

In the Riverview and Bull Canyon subbasins, unconsolidated sediments are mainly flood-plain deposits of the Carson River consisting of moderate to well-sorted silty fine sand and sandy gravel (Bingler, 1977). In the Mound House subbasin, unconsolidated sediments are poorly to moderately sorted alluvialplain deposits consisting of silt, sand, gravel, and cobbles (Bingler, 1977). Lake Lahontan sediments are found in the Carson Plains subbasin east of Dayton. Based on descriptions from drillers' logs, the sediments consist of several hundred feet of alternating layers of sand, gravel, silt, and clay, becoming coarser and grading to poorly sorted alluvial-fan sediments with increasing amounts of sand and gravel near the margins of the valley (Moore, 1969, p. 15; Bonham, 1969, p. 42). In the Stagecoach subbasin, unconsolidated sediments are generally fine-grained Lake Lahontan and playa deposits (Harrill and Preissler, 1994, p. H5).

Unconsolidated sediments form the major aquifers in the subbasins. Generally, these sediments have low permeability where fine grained, are moderately permeable where coarser grained and poorly sorted, and are highly permeable where coarse grained and well sorted. Municipal, domestic, and agricultural wells produce water from the more permeable sediments in the unit.

The total thickness of both unconsolidated and partly consolidated sediments can be estimated from drillers' logs and by using geophysical methods. Because unconsolidated and partly consolidated sediments are difficult to distinguish during drilling and by geophysical methods, their individual thicknesses are poorly known. Their total thickness is described as the thickness of basin-fill sediments in each subbasin.

According to drillers' logs, basin-fill sediments are about $300 \mathrm{ft}$ thick near the Carson River east of well R-9s (app. 2, pl. 3) and about $700 \mathrm{ft}$ thick beneath the boundary between Eagle Valley and the Riverview subbasin (inset, pl. 2). Basin-fill sediments are thin in the Mound House subbasin; they are generally described as $100-140 \mathrm{ft}$ thick on most drillers' logs. In the westernmost Carson Plains subbasin, basin-fill sediments are about $170 \mathrm{ft}$ thick at well C-6 (pl. 3) and almost $300 \mathrm{ft}$ thick near well C-2. At well C-16, basin-fill sediments are $360 \mathrm{ft}$ thick and are over $600 \mathrm{ft}$ thick near the Carson River at the eastern boundary of the Carson Plains subbasin. Analysis of gravity data suggests that basin-fill sediments have a maximum thickness of 2,900 ft near the base of the mountain front about 3 mi northeast of Dayton (Schaefer and Whitney, 1992, p. 8). Gravity data in the Stagecoach subbasin show that basin-fill sediments could be as thick as 3,000 ft about 2 mi south of U.S. Highway 50 (Harrill and Preissler, 1994, p. H13). Drillers' logs show basinfill sediments over $500 \mathrm{ft}$ thick near the Carson River in the Bull Canyon subbasin.

\section{HYDROLOGY}

\section{Estimates of Annual Precipitation}

Infiltration of precipitation and of streamflow along the Carson River and its tributaries are the two most important sources of ground-water recharge. Stations recording precipitation are sparse within the study area and data from the highest altitudes, where precipitation is thought to be greatest, are lacking. Thus, the distribution of precipitation over the study area is not known and must be estimated. Three different approaches were used to estimate the distribution of annual precipitation and to develop a range of values for mean annual precipitation.

\section{Altitude-Precipitation Relation of Glancy and Katzer (1976)}

Annual precipitation in the Dayton Valley Hydrographic Area was previously estimated by Glancy and Katzer (1976, p. 48) using a relation between altitude and annual precipitation of the sort described by Eakin (1960). This relation is the first step in a method, commonly called the Maxey-Eakin method, used to estimate ground-water recharge in the state of Nevada (Watson and others, 1976, p. 339-342). The relation described by Eakin (1960) assigns a range in annual precipitation to a range in altitude, with precipitation increasing as altitude increases (app. 1). The relation was developed from a map of mean annual precipitation for Nevada produced by Hardman and others (1936), Hardman and Mason (1949, p. 10) and later revised by Hardman (1965). For the reconnaissance study (Glancy and Katzer, 1976, p. 48), the area between altitude zones was mechanically planimetered from 1:250,000-scale topographic maps (Patrick A. Glancy, U.S. Geological Survey, oral commun., 1995). 
The resulting distribution of the volume of mean annual precipitation in the study area is shown in table 2.

For the present study, estimates of precipitation for the hydrographic area and for each subbasin were made using the same altitude-precipitation relation used by Glancy and Katzer (1976, p. 48). A digital elevation model at a scale of 1:250,000 was used to determine estimates of precipitation and area. The digital elevation model consists of 2-acre cells forming a grid over the study area, with an average altitude assigned to each cell. ARC-INFO software was used to apply the altitude-precipitation relation to each grid cell and total the estimated precipitation and area within each altitude zone. The volume of mean annual precipitation was then calculated for the hydrographic area (table 2) and for each subbasin (app. 1).

The resulting volumes of mean annual precipitation range from 9,100 acre-ft/yr in the Riverview subbasin to 89,000 acre-ft/yr in the Carson Plains subbasin (app. 1). For the entire hydrographic area, mean annual precipitation is estimated to be 180,000 acre- $\mathrm{ft} / \mathrm{yr}$ (table 2). Other than differences probably caused by the different methods used to determine area, the estimates obtained in this study and those reported in the reconnaissance study are the same.

\section{Distance-Altitude Relation}

Many additional precipitation data have been collected since the relation between precipitation and altitude was developed for the Maxey-Eakin method. Also, inspection of the Hardman (1965) precipitation map suggests that, in western Nevada, annual precipitation is also controlled by the distance from the Sierra Nevada (the rain-shadow effect). Hardman's map shows annual precipitation decreasing from 8-12 in/yr in valleys adjacent to the Sierra to less than $5 \mathrm{in} / \mathrm{yr}$ in valleys $30-40 \mathrm{mi}$ east of the Sierra. Spane $(1977$, p. 54) also notes the rain-shadow effect of the Sierra in estimating annual precipitation on the floor of Carson Valley.

To include more recent precipitation data and the effect of distance from the Sierra, a relation between mean annual precipitation, altitude, and distance from the crest of the Sierra was developed for the Dayton Valley Hydrographic Area using data from five NOAA climate stations and two stations operated by the Nevada State Climatologist's Office (table 1). Published values of mean annual precipitation are available for the period 1961-90 (Owenby and Ezell, 1992). However, the station at Virginia City was moved to the west and to a higher altitude in 1968 , collecting greater amounts of precipitation. For this reason, mean annual precipitation for the period 196994 was used to develop the relation. Mean annual precipitation at the Como-Rawe and Lebo Spring stations, operated by the State Climatologist, has been estimated

Table 2. Mean annual precipitation for Dayton Valley Hydrographic Area, Nevada, from three different relations for distribution of precipitation (app. 1)

\begin{tabular}{|c|c|c|}
\hline $\begin{array}{l}\text { Precipitation } \\
\text { range } \\
\text { (inches) }\end{array}$ & $\begin{array}{c}\text { Area } \\
\text { (acres) }\end{array}$ & $\begin{array}{l}\text { Estimated } \\
\text { precipitation } \\
\text { (acre-feet) }\end{array}$ \\
\hline \multicolumn{3}{|c|}{ From Glancy and Katzer (1976, p. 48) } \\
\hline$>20$ & 698 & 1,300 \\
\hline $15-20$ & 10,600 & 16,000 \\
\hline $12-15$ & 43,900 & 48,000 \\
\hline $8-12$ & 74,900 & 60,000 \\
\hline$<8$ & 103,000 & 52,000 \\
\hline Total (rounded) . . & 233,100 & 180,000 \\
\hline \multicolumn{3}{|c|}{$\begin{array}{c}\text { From altitude-precipitation relation of } \\
\text { Glancy and Katzer (1976), } \\
\text { using digital elevation model }\end{array}$} \\
\hline$>20$ & 742 & 1,400 \\
\hline $15-20$ & 10,000 & 16,000 \\
\hline $12-15$ & 43,600 & 48,000 \\
\hline $8-12$ & 74,200 & 59,000 \\
\hline$<8$ & 105,300 & 53,000 \\
\hline Total (rounded) & 233,000 & 180,000 \\
\hline
\end{tabular}

From distance-altitude relation

\begin{tabular}{crr}
$>20$ & 176 & 300 \\
$15-20$ & 19,300 & 27,000 \\
$12-15$ & 50,800 & 56,000 \\
$8-12$ & 102,300 & 83,000 \\
$<8$ & 61,600 & 37,000 \\
\cline { 2 - 3 } Total (rounded) $\ldots$ & 234,200 & 200,000
\end{tabular}

From 1996 Nevada precipitation map

\begin{tabular}{ccc}
$>20$ & 29,200 & 53,000 \\
$15-20$ & 46,600 & 69,000 \\
$12-15$ & 41,400 & 46,000 \\
$8-12$ & 76,700 & 62,000 \\
$<8$ & 41,300 & 21,000 \\
\cline { 2 - 3 } & 235,200 & 250,000 \\
\hline
\end{tabular}


only for the period 1961-90 (James, 1995), and these values were used to develop the relation. The use of mean values for different periods of record produces some uncertainty in the resulting relation; however, the difference between mean values for the two time periods is less than 10 percent at all sites (table 1 ). The distance from the Sierra crest was measured as the distance between each station and longitude $120^{\circ}$ west, which approximates the crest of the Sierra.

Mean annual precipitation for the seven stations and the principle of least squares (Iman and Conover, 1983, p. 360-361) were used to develop the following equation between mean annual precipitation, station altitude, and station distance from the Sierra crest:

Mean annual precipitation (inches per year) $=$ $-5.16+0.00323 \mathrm{x}$ altitude (feet)

$-0.074 \times$ distance (miles).

The regression statistic, $\mathrm{R}$-squared, is a measure of how well the equation explains the data. A perfect fit of the equation to the data would give an R-squared of 1.00 ; $\mathrm{R}$-squared for equation 1 is 0.97 . This indicates that equation 1 is useful for estimating mean annual precipitation within the study area. The accuracy of the equation above $7,200 \mathrm{ft}$, the altitude of the highest station used in the relation, is unknown. Despite this uncertainty, equation 1 provides an estimate of mean annual precipitation using recent data collected in and near the study area.

Again, the digital elevation model and computer software were used to apply the relation and calculate the volume of annual precipitation for precipitation zones within the entire hydrographic area (table 2) and for each subbasin (app. 1). The relation in equation 1 predicts from 13 to 21 percent more precipitation for the subbasins than does the relation used by Glancy and Katzer (1976, p. 48). For the entire hydrographic area, mean annual precipitation is estimated to be 200,000 acre- $\mathrm{ft} / \mathrm{yr}$ (table 2). The area estimated to receive less than $8 \mathrm{in} / \mathrm{yr}$ is much less than that of the relation used by Glancy and Katzer (1976, p. 48), and larger areas are generally estimated for the other precipitation zones except where mean annual precipitation exceeds 20 in.

\section{PRISM Model of Daly and Others (1994)}

A third estimate of the volume of mean annual precipitation was calculated using a map showing mean annual precipitation, 1961-90, for the State of Nevada (John W. James, Nevada State Climatologist, written commun., January 1996). This map, hereafter referred to as the 1996 Nevada precipitation map, was produced using a computer model called Precipitationelevation Regressions on Independent Slopes (PRISM) by Oregon State University (Daly and others, 1994). The model used digital elevation models of the State and data from precipitation stations to derive a grid of estimated precipitation. Lines of equal precipitation were drawn using the grid.

The January 1996 version of the Nevada precipitation map is at a scale of $1: 1,750,000$. The original map was scanned, the scale expanded, and matched to county-line and subbasin boundaries plotted at a scale of approximately 1:272,000. In some locations, closed precipitation contours, assumed to represent precipitation maxima near the highest peaks, did not exactly coincide with the subbasin boundaries which cross the peaks. For these reasons, estimates of precipitation using the map are considered approximate, but they provide a third, independent estimate of the volume of mean annual precipitation. The area of the precipitation zones within each subbasin was determined using a mechanical planimeter. Total areas determined for each subbasin and for the entire hydrographic area were within about 2 percent of those obtained digitally (app. 1).

The volume of mean annual precipitation estimated using the 1996 Nevada precipitation map is considerably greater than estimates made by the other two methods. For the subbasins, the map estimates from 18 to 54 percent more precipitation than the relation used by Glancy and Katzer (1976, p. 48) (app. 1). For the entire hydrographic area, the volume of mean annual precipitation is estimated to be 250,000 acre$\mathrm{ft} / \mathrm{yr}$, about 40 percent more than that estimated using the relation of Glancy and Katzer (1976, p. 48) (table 2 ). The areas estimated to receive more than $15 \mathrm{in} / \mathrm{yr}$ are much greater than areas estimated using the other two methods (table 2). Collecting additional precipitation data above altitudes of $7,000 \mathrm{ft}$ would show which method is most accurate.

\section{Surface Water}

Surface water in the study area is dominated by streamflow in the Carson River and its diversions. Most other streams in the area are ephemeral and flow along their entire course only during spring snowmelt or summer thunderstorms. The Carson River gains or loses flow to ground water throughout much of the study area. 


\section{Carson River and Diversions}

Maximum flow of the river is normally from April to June when the snowpack melts in the Sierra Nevada. However, floods have occurred from December through February when rain is added to the snowpack during warm winter storms. Runoff from April through June usually accounts for about half of the total annual streamflow (Clary and others, 1995, p. 206). Streamflow decreases through the summer, and the lowest flows are in September. At the eastern boundary of the study area during dry years, the river can become dry by August or September. After this time, flows gradually increase through fall and winter months.

Flow of the Carson River is gaged at four stations in and near the Dayton Valley Hydrographic Area (pl. 1, table 3). Long-term records of streamflow are available for both the upstream boundary (Carson City gage) and downstream boundary (Fort Churchill and Buckland Ditch gages) of the Dayton Valley Hydrographic Area. Flow of the river has been gaged for a total of 10 years at the downstream boundary of the Riverview subbasin (Deer Run Road gage), and for only 1 year about 2 mi northeast of the upstream boundary of the Carson Plains subbasin (Dayton gage). In addition, streamflow from the Eagle Valley Hydrographic Area to the Riverview subbasin has been gaged at Eagle Valley creek for about 10 years (pl. 1). The Federal Water Master also maintains records of diversions from the Carson River for irrigation since 1978.

The average annual flow of the Carson River reported at each gage depends greatly on the period of record (table 3). Comparison of average annual river flow at each gage can be made from averages calculated for the common 10-year period of record (water years 1980-85 and 1991-94, table 3). A water year extends from October 1 to September 30, and is designated by the calendar year in which it ends.

The resulting average flow at the gage near Carson City is 332,000 acre-ft/yr, and 332,000 acre$\mathrm{ft} / \mathrm{yr}$ at the Deer Run Road gage. Downstream from the Carson City gage, flow is diverted to Mexican Ditch where, from 1978 through 1994, an average of about 6,800 acre-ft/yr was diverted from April through September (Federal Water Master, written commun., 1994). Downstream from the diversion of Mexican Ditch, Eagle Valley creek exits Eagle Valley, enters the Dayton Valley Hydrographic Area, and is tributary to the Carson River with an average flow of 2,200 acre-ft/yr (1985-94). Downstream from Eagle Valley creek, three small streams exit Eagle Valley and are tributary to the Carson River, but the flow of these creeks is unknown.

In the Mound House subbasin, Brunswick Canyon and other smaller canyons supply flow to the river only during periods of high flow. Springs provide small amounts of perennial flow to the river (pl. 3). In the Carson Plains and Bull Canyon subbasins, diversions from the Carson River average about 22,000 acre-ft/yr from May to September (pl. 2, table 3). Eldorado and Six-Mile Canyons and other smaller canyons supply flow to the river only during periods of high flow.

Average flow of the Carson River near Fort Churchill for the common period of record is 312,200 acre-ft/yr. In addition to this flow, irrigation diversions in the Buckland Ditch leave the hydrographic area and average about 10,000 acre-ft/yr, for a total of about 322,200 acre-ft/yr.

\section{Ephemeral Streams and Springs}

The major ephemeral streams that are tributary to the Carson River are in Brunswick, Eldorado, and SixMile Canyons (pl. 1). A crest-stage gage has recorded peak stages in the Brunswick Canyon stream since 1966. Records of the U.S. Geological Survey show that peak flows $60 \mathrm{ft}^{3} / \mathrm{s}$ or greater were recorded in March $1967\left(63 \mathrm{ft}^{3} / \mathrm{s}\right)$, January $1969\left(60 \mathrm{ft}^{3} / \mathrm{s}\right)$, January 1980 $\left(63 \mathrm{ft}^{3} / \mathrm{s}\right)$, July $1984\left(90 \mathrm{ft}^{3} / \mathrm{s}\right)$, February $1986(180$ $\left.\mathrm{ft}^{3} / \mathrm{s}\right)$, July $1994\left(75 \mathrm{ft}^{3} / \mathrm{s}\right)$, and March $1995\left(245 \mathrm{ft}^{3} / \mathrm{s}\right)$. In February of 1986 , peak flow was $2,100 \mathrm{ft}^{3} / \mathrm{s}$ at Eldorado Canyon, $500 \mathrm{ft}^{3} / \mathrm{s}$ at Six-Mile Canyon, and $850 \mathrm{ft}^{3} / \mathrm{s}$ at Gold Canyon (Pupacko and others, 1988, p. 216). Peak flows in these canyons are of short duration and provide relatively small amounts of flow to the Carson River.

Numerous small springs are scattered throughout the mountain blocks in the study area. Of note are several small springs near Silver City that provide water for the municipal system in Mound House. At Sutro Springs north of Carson Plains, $10 \mathrm{ft}^{3} / \mathrm{s}$ was measured on July 23, 1972, and at Sutro Tunnel, which is a collapsed drainage tunnel from deep mine shafts of the Comstock Lode, $37.5 \mathrm{ft}^{3} / \mathrm{s}$ was measured on June 1 , 1970. Typically, springs support a small area of phreatophytes near the spring orifice, and flow is quickly lost to infiltration. 
Table 3. Information for surface-water gaging stations in and near Dayton Valley Hydrographic Area, Nevada. Gage sites are shown on plate 1; ditches are shown on plate 2

[Abbreviation: acre-ft/yr, acre-feet per year. Symbol: --, data not available for computation]

\begin{tabular}{|c|c|c|c|c|}
\hline $\begin{array}{c}\text { Station } \\
\text { number }\end{array}$ & Station name & $\begin{array}{c}\text { Period of } \\
\text { record } \\
\text { (water years) }\end{array}$ & $\begin{array}{l}\text { Average flow } \\
\text { for period } \\
\text { of record } \\
\text { (acre-ft/yr) }\end{array}$ & $\begin{array}{c}\text { Average flow } \\
\text { for water years } \\
1980-85 \text { and } \\
1991-94 \\
\text { (acre-ft/yr) }\end{array}$ \\
\hline 10311000 & Carson River near Carson City. . & May 1939-Sept. 1994. . . & 2284,100 & 332,000 \\
\hline- & Mexican Ditch . ........... & 1978-94, May-Sept. . . . & ${ }^{3} 6,800$ & - \\
\hline 10311300 & Eagle Valley creek near Carson City .... & Jan. 1985-Sept. $1994 \ldots$ & ${ }^{2} 2,200$ & -- \\
\hline 10311400 & Carson River at Deer Run Road. . . . . . . & $\begin{array}{l}\text { April 1979-Sept. 1985, Aug. } \\
\text { 1990-Sept. } 1994 .\end{array}$ & 2332,000 & 332,000 \\
\hline \multirow[t]{2}{*}{10311700} & Carson River near Dayton . . . . . . . . & April-Sept. 1994. . . . . . & -- & -- \\
\hline & Carson Plains Diversions & & & \\
\hline-- & Rose ditch. & 1978-94, May-Sept. . . . . & ${ }^{3} 1,700$ & -- \\
\hline-- & Dayton ditch $\ldots \ldots \ldots \ldots \ldots \ldots \ldots$ & do. & ${ }^{4} 1,800$ & -- \\
\hline- & Fish ditch $\ldots \ldots \ldots \ldots \ldots \ldots \ldots$ & do. & ${ }^{3} 1,600$ & -- \\
\hline -- & Baroni ditch ..... & do. & ${ }^{3} 2,700$ & -- \\
\hline-- & Cardelli ditch . . & do. & ${ }^{3} 6,200$ & -- \\
\hline-- & Quilici ditch & do. & ${ }^{3} 2,400$ & -- \\
\hline-- & Gee ditch... & do. & ${ }^{3} 800$ & -- \\
\hline-- & Chaves ditch $\ldots \ldots \ldots \ldots \ldots \ldots \ldots$ & do. & ${ }^{3} 3,200$ & -- \\
\hline \multirow[t]{2}{*}{--} & Houghman \& Howard ditch . . . . . . . & do. & ${ }^{3} 1,300$ &.- \\
\hline & Total for Carson Plains diversions . & & 22,000 & \\
\hline 10311900 & Buckland Ditch near Fort Churchill. .... & $\begin{array}{l}\text { July 1962-Sept. } 19711978-94 \text {, } \\
\text { May-Sept. 1978-94. }\end{array}$ & $\begin{array}{r}516,160 \\
35,300 \\
611,500\end{array}$ & ${ }^{6} 10,000$ \\
\hline 10312000 & Carson River near Fort Churchill . . . . . . . & April 1911-Sept. $1994 \ldots$ & ${ }^{2} 262,000$ & 312,000 \\
\hline
\end{tabular}

${ }^{1}$ Eight-digit number is used to identify each stream- and spring-gaging station. For example, station number 10311000 consists of twodigit part number (10) followed by six-digit downstream-order number (311000). Part number refers to drainage area or group of areas that is generally regional in extent. Records in this report are for sites in part 10 (Great Basin). Downstream-order number is assigned according to geographic location of station in drainage network; larger number stations are downstream from smaller number stations.

${ }^{2}$ Clary and others (1995, p. 206, 214, 215, 222).

${ }^{3}$ Federal Water Master's records for May through September.

${ }^{4}$ Federal Water Master's records for May through September; out of service in 1988.

${ }^{5}$ U.S. Geological Survey (1972, p. 76).

${ }^{6}$ Estimated for entire water year by assuming ratio of May- September flow to total annual flow in water years 1963-71 was the same for water years 1978-94, 1980-85, and 1991-94.

\section{Estimated Gains and Losses for the Carson River}

Interchange of water between the Carson River and the underlying basin-fill sediments is potentially a large component of the ground-water budget for the area. However, accurate measurement of the volumes of water moving between the river and the basin-fill sediments is difficult because the rate at which water moves in the subsurface is small compared to the normal flow of the Carson River. Thus, even the most accurate measurements of streamflow might not be sufficient to determine the volume of interchange.

Estimates of flow gains and losses can be made using the mean annual flow volumes recorded at the gaging stations. However, the accuracy of the gaged streamflow makes the estimates approximate. 
Streamflow into the Riverview subbasin from the Carson River and Eagle Valley creek totals about 334,000 acre-ft/yr (table 3). Outflow from the subbasin at the Deer Run Road gage is 332,000 acre-ft/yr. The difference, about 2,000 acre-ft/yr ( 0.6 percent of annual flows recorded at main stem gages), suggests a loss through the reach. However, the reported accuracy of records for the Carson River is fair at the Carson City gage ( 95 percent of the daily discharges are within 15 percent of their true values) and poor at the Deer Run Road gage ( 95 percent of the daily discharges are more than 15 percent different from their true values). Thus, the apparent difference in average flows at the two boundaries might not be meaningful.

At the downstream boundary of the study area, streamflow totals 322,000 acre- $\mathrm{ft} / \mathrm{yr}$ from the Carson River near Fort Churchill and irrigation diversions in the Buckland Ditch (table 3). Flow in the Buckland Ditch has been gaged for the entire water year only from 1963 to 1971; flow from May to September has been reported by the Federal Water Master from 1978 through 1994. The average annual flow of 10,000 acre$\mathrm{ft} / \mathrm{yr}$ was estimated by assuming that the ratio of Mayto-September flow to total annual flow from 1963 to 1971 was the same for water years $1980-85$ and 199194. In recent years, diversions through Buckland Ditch have been managed to provide more efficient use of water during the nonirrigation season (Garry Stone, Federal Water Master, oral commun., 1995). Thus, the value of 10,000 acre-ft/yr could be overestimated.

The difference between outflow near Fort Churchill and inflow of the Carson River at Deer Run Road implies a loss of about 10,000 acre-ft/yr through the Mound House, Carson Plains, and Bull Canyon subbasins. Again, accuracy of the gaged flows (record accuracy at the Fort Churchill gage is reported as fair), and the estimated value for flow of the Buckland Ditch, makes this value approximate. Also, additional gains or losses could take place through the reach.

When more record is available at the Carson River at Dayton gage, a similar analysis can be made for stream losses through the Mound House subbasin and from Carson Plains through the Bull Canyon subbasin.

Instantaneous measurements of flow that have been made at several points along the Carson River through the study area provide more accurate data from which to estimate gains and losses. These types of measurements are called seepage measurements and are generally made during periods of low flow when the accuracy of individual measurements (about 5 percent) will provide the most meaningful differences in measured flow. Because measurements are made at low flows, flow losses provide only minimum loss rates. Measured flow gains are probably more representative of the average rate of groundwater discharge to the channel, because rates of ground-water flow are more constant than the rates of surface-water flow.

The first recorded seepage measurements in the Dayton Valley Hydrographic Area were made during September 1966 (U.S. Geological Survey, 1974, p. 1132 and 1133). Two other seepage measurements were made, in September of 1992 and 1994 (Hess and others, 1993, p. 404-405; Clary and others, 1995, p. 556-557). During all three seepage measurements, flows ranged from about 10 to less than $1 \mathrm{ft}^{3} / \mathrm{s}$. In analyzing the flow measurements, streamflow is assumed to be in equilibrium and it is assumed that no unmeasured tributary flow is entering, diverted flow is leaving, the river channel between measurement sites. Table 4 summarizes the rates of gains and losses measured across each subbasin.

In the Riverview subbasin, seepage measurements indicate a net loss of flow ranging from 3.6 to $9.6 \mathrm{ft}^{3} / \mathrm{s}$. During 1966 and 1992, flow losses of 2.6 and $1.7 \mathrm{ft}^{3} / \mathrm{s}$, respectively, were measured between the Carson City gage and the diversion for Mexican Ditch (U.S. Geological Survey, 1974, p. 1132; Hess and others, 1993, p. 404). Measurements show a net loss of flow in the Mound House subbasin ranging from 0.9 to $3.0 \mathrm{ft}^{3} / \mathrm{s}$ (table 4). However, during 1994 , a reach extending about 4 mi downstream from the Deer Run Road gage gained about $2.0 \mathrm{ft}^{3} / \mathrm{s}$ (Clary and others, 1995, p. 556). In the Carson Plains subbasin, measurements show a net gain in streamflow ranging from 2.2 to $4.9 \mathrm{ft}^{3} /$ s. During 1966 , measurements suggest a losing reach from the western boundary of the Carson Plains subbasin to about 2 mi northeast of Dayton (U.S. Geological Survey, 1974, p. 1132). However, it is not clear if diversions for irrigation south of the river were active or accounted for at that time. In the Bull Canyon subbasin during that same year, flow losses ranging from 3.3 to $4.9 \mathrm{ft}^{3} / \mathrm{s}$ were measured.

Seepage measurements indicate that the Carson River loses flow through all subbasins, except Carson Plains, in the Dayton Valley Hydrographic Area. During 1994, some wells near the downstream end of the Carson Plains subbasin were observed to be 
Table 4. Gain or loss of Carson River streamflow in subbasins of Dayton Valley Hydrographic Area, Nevada, based on seepage measurements and simulations

[Abbreviations: $\mathrm{ft}^{3} / \mathrm{s}$, cubic feet per second; acre-ft/yr, acre-feet per year.]

\begin{tabular}{|c|c|c|}
\hline \multicolumn{2}{|c|}{ Seepage measurements } & \multirow{2}{*}{$\begin{array}{l}\text { Average difference } \\
\text { in flow, from } \\
\text { simulations }{ }^{1} \\
\text { (acre-ft/yr) }\end{array}$} \\
\hline Date & $\begin{array}{l}\text { Difference in flow } \\
\left(\mathrm{ft}^{3} / \mathrm{s}\right)\end{array}$ & \\
\hline \multicolumn{3}{|c|}{ Riverview } \\
\hline $9-8-66$ & $3.6 \operatorname{loss} 2$ & \multirow{5}{*}{3,000 loss } \\
\hline $9-9-92$ & 4.2 Ioss $^{3}$ & \\
\hline $9-28-94$ & $9.6 \operatorname{loss}^{4}$ & \\
\hline Average & 5.8 Ioss & \\
\hline & $(4,200$ acre-ft/yr) & \\
\hline \multicolumn{3}{|c|}{ Mound House } \\
\hline $9-8-66$ & 0.9 loss $^{2}$ & \multirow{5}{*}{2,100 loss } \\
\hline $9-9-92$ & $3.0 \operatorname{loss}^{3}$ & \\
\hline $9-28-94$ & $2.6 \operatorname{loss}^{4}$ & \\
\hline Average & 2.2 loss & \\
\hline & $(1,600$ acre-ft/yr $)$ & \\
\hline \multicolumn{3}{|c|}{ Carson Plains } \\
\hline $9-8-66$ & 4.9 gain $^{2}$ & \multirow{5}{*}{21 gain } \\
\hline $9-9-92$ & 2.2 gain $^{3}$ & \\
\hline $9-28-94$ & 2.8 gain $^{4}$ & \\
\hline Average & 3.3 gain & \\
\hline & $(2,400$ acre-ft/yr) & \\
\hline \multicolumn{3}{|c|}{ Bull Canyon } \\
\hline $9-8-66$ & $4.9 \mathrm{Ioss}^{2}$ & \multirow{5}{*}{1,900 loss } \\
\hline $9-9-92$ & 4.0 loss $^{3}$ & \\
\hline $9-28-94$ & $3.3 \operatorname{loss}^{4}$ & \\
\hline Average & 4.1 loss & \\
\hline & $(3,000$ acre-ft/yr) & \\
\hline
\end{tabular}

Net loss, in acre-ft/yr $\quad 6,400$

7,000

${ }^{1}$ Average for water years 1980-85 and 1991-94 from Glen W. Hess, U.S. Geological Survey, written commun., 1996.

${ }^{2}$ U.S. Geological Survey, 1974, p. 1132-1133.

${ }^{3}$ Hess and others, 1993 , p. 404-405.

${ }^{4}$ Clary and others, 1995 , p. 556-557.

pumping. Some part of the gains in flow in this and other years could be attributed to irrigation return flow from ground-water pumping in the fall of dry years to provide irrigation for winter forage. Additional seepage measurements would allow confirmation and refinement of streamflow gains through the Carson Plains subbasin.
A recently developed surface-water flow model of the Carson River provides additional, and probably more accurate, estimates of streamflow gains and losses through the study area (Hess, 1996). This model is a physically based flow-routing model using a computer code called Hydrological Simulation ProgramFORTRAN (HSPF; Bicknell and others, 1993). The model uses a modified kinematic-wave algorithm to route flow within 2- to 3-mi reaches of the river. The model summarizes available streamflow data from gaging stations and diversion data from the Federal Water Master. Daily streamflow is modeled using the flow data, measured stream cross sections, channel slope and roughness, estimates of evaporation rates, losses to phreatophytes, return flow, tributary inflow, and constant gains from or losses to ground water. The model predicted observed annual streamflow at the Deer Run Road gage within 1.6 percent for water years 1990-92, and matched observed annual streamflow at the Fort Churchill gage for water years 1978-92 (Glen W. Hess, U.S. Geological Survey, written and oral communs., 1996). Seepage measurements discussed above were used to control model calculations of daily ground-water gains and losses.

Daily gains from and losses to ground water calculated by the model for reaches within each subbasin were summarized (Glen W. Hess, U.S. Geological Survey, written commun., 1996) and average values were calculated for a 10-year period (water years 198085 and 1991-94, table 4). The resulting average annual gains and losses are considered to be better estimates than those obtained using the average of the three seepage measurements. In the Riverview, Mound House, and Bull Canyon subbasins, the model simulated losing reaches for each year of the simulation, resulting in average annual losses of $3,000,2,100$, and 1,900 acre$\mathrm{ft} / \mathrm{yr}$, respectively. In the Carson Plains subbasin, the model simulated a net loss in normal-to-wet years and a net gain during dry years, resulting in an average annual gain of 21 acre-ft/yr over the 10-year period. This result seems reasonable because the Carson Plains subbasin has a broad alluvial plain in which the ground-water gradient replicates the channel gradient of the Carson River. Thus, small differences in stream stage and ground-water levels can change the reach from gaining to losing. The interchange of water between the Carson River and the ground-water system in the broad alluvial plain is complex and variable. 
To provide a qualitative check on the seepage measurements and results of the model simulations, water levels in 13 wells near the Carson River were surveyed relative to stream stage in the fall of 1995 . The data also allow the potential for interchange between the Carson River and ground water on a single side of the stream channel to be assessed. Where the altitude of the stream stage is higher than the water level in the adjacent aquifer, the reach has potential to lose flow and supply recharge to ground water. Conversely, where the water level in the adjacent aquifer is higher than the stream stage, ground water potentially can discharge to the river. The rate at which water moves between the two systems is determined by the difference in water level between the aquifer and stream and the hydraulic conductivity of sediments through which the water moves.

For each site, the gradient between water levels in the aquifer and in the stream, and whether each reach is gaining and losing, is indicated in table 5. The horizontal distance used to calculate the gradient was measured perpendicular from the river to the well. A component of ground-water flow could exist in a direction subparallel to the river. Thus, the horizontal distance is a minimum value, and the gradient is a maximum value. The gradient values are presented for comparison with future measurements. The range in stream stage recorded from peak flows during March 1995 during runoff of a wet year, to low flow in September 1995, was about $8 \mathrm{ft}$ at the Carson City gage, about $10 \mathrm{ft}$ at the Deer Run Road gage, and about $7 \mathrm{ft}$ at the Dayton gage. Water-level data in March are not available for the measured wells. Additional waterlevel measurements during high-stream stage in the spring would determine the change in flow direction and gradient.

In the Riverview subbasin, water levels in wells on the west side of the river (wells R-5 and R-17) indicate ground-water flow to the river. Seepage losses from the Mexican Ditch and subsurface flow from the Eagle Valley Hydrographic Area probably maintain high ground-water levels on the west side of the river. On the east side of the river at well R-18 (pl. 3), measurements indicate flow from the river to ground water, with a large difference in head. Wells R-12 and R-16 east of the river show small differences in head, suggesting that the river has a potential to gain flow during low flows and to lose flow during periods of moderately high stream stage. In the Mound House subbasin, well M-12 shows that the reach is losing, with a large difference in head.
Table 5. Vertical difference in altitude and hydraulic gradients measured between ground-water level and river stage for selected sites in Dayton Valley Hydrographic Area, Nevada

\begin{tabular}{ccccc}
\hline $\begin{array}{c}\text { Site } \\
\text { (pl. 3, } \\
\text { app. 2) }\end{array}$ & Date & $\begin{array}{c}\text { Vertical } \\
\text { difference } \\
\text { (feet) }\end{array}$ & $\begin{array}{c}\text { Horizontal } \\
\text { distance } \\
\text { (feet) }\end{array}$ & $\begin{array}{c}\text { Hydraulic } \\
\text { gradient }\end{array}$ \\
\hline (feet per foot)
\end{tabular}

${ }^{1}$ Vertical difference is water-level altitude minus stream-stage altitude. Positive value indicates gaining reach; negative value indicates losing reach

\footnotetext{
${ }^{2}$ Measured perpendicular from river to well. If component of down-valley ground-water flow exists, listed value is a minimum.

${ }^{3}$ Positive value indicates gaining reach; negative value indicates losing reach. Because horizontal distance is a minimum value, listed gradient is a maximum.

${ }^{4}$ Stream stage estimated.
}

In the western part of the Carson Plains subbasin, measurements at most wells (C-17, C-19, C-23, and $\mathrm{C}-31$ ) indicate ground-water flow to the river. Observation well C-14 near the town of Dayton is near a municipal supply well, which is also near the river, and probably induces flow from the river to ground water. At well C-29 and in the Bull Canyon subbasin (well B-1), measurements indicate flow from the river to ground water. Thus, at moderate stream stages, the river should become a losing reach about $4 \mathrm{mi}$ 
northeast of Dayton. Seepage measurements made only at the boundaries of the subbasin could include the effects of both gaining and losing reaches.

Measurements of river stage and ground-water levels show that gains to and losses from the Carson River differ with location along the river, from one bank to the other, and with stream stage. Existing data do not allow accurate estimates of the volumes of water gained by or lost from the Carson River. Installation of additional wells would allow gaining and losing reaches to be more closely delineated, and allow more meaningful seepage measurements to be made. These data would allow more accurate estimates of the volumes of water interchanged between the Carson River and the adjacent aquifers.

\section{Ground-Water Distribution and Movement}

Ground water moving through consolidated rocks and basin-fill sediments in the study area can originate from (1) precipitation within the study area, (2) streamflow in the Carson River and its tributaries, (3) subsurface flow from adjacent areas, or (4) water imported from outside the hydrographic area.

Ground water originating from precipitation flows from the mountain blocks toward the valley floors. Part of the precipitation that falls on the mountain blocks is lost to the atmosphere by evaporation and by transpiration of vegetation, part runs off as streamflow, and part infiltrates into weathered or fractured zones in consolidated rocks or alluvium beneath the stream channels. Water that infiltrates can flow toward streams and seep into stream channels where the water table is higher than the stream bed, or move beneath the stream channels toward the valley floors. Where the water table is lower than the bottom of stream channels, streamflow infiltrates to recharge ground water. Data presented by Thomas and Lawrence (1994, p. 45) on the carbon-14 age of ground water show that ground water from two wells in the Carson Plains subbasin near the base of the Virginia Range and the Pine Nut Mountains is of recent age and this ground water probably was recharged by infiltration of streamflow from the mountains. Ground-water recharge from precipitation on the valley floors is thought to be minimal (Glancy and Katzer, 1976, p. 47).

Water flows from the Carson River and its diversions to the adjacent aquifer where the water table is lower than the stream stage. Geochemical data also show recent recharge to ground water near the river
(Thomas and Lawrence, 1994, p. 20 and 45). However, because ground-water discharge by crops and phreatophytes is concentrated along the river channel, some part of the stream losses supports consumptive use by vegetation. Most ground-water recharge from streamflow of the Carson River probably occurs during winter months when evapotranspiration is minimal and stream stage is high. Some or all of this recharge could be lost during summer months when stream stage declines and evapotranspiration rates are at a maximum.

Under natural conditions, ground water originating from infiltration along the Carson River might not move far from the channels of the river and its diversions. The carbon-14 age of ground water about $1 \mathrm{mi}$ north of the river near the eastern boundary of the Carson Plains subbasin is about 4,800 years (Thomas and Lawrence, 1994, p. 45). Additional data on tritium concentrations and carbon-14 ages would more clearly show the extent of recharge from the Carson River.

The boundaries between hydrographic areas and between subbasins of the Dayton Valley Hydrographic Area are based mainly on topography and are not necessarily ground-water divides. Where ground-water levels are higher on one side of a boundary than on the other, the potential for interbasin flow exists. The rate and volume of interbasin flow depends on the gradient across the boundary and the permeability of aquifer materials beneath the boundary.

Imported water that infiltrates to the water table is also a source of recharge to ground water. Water is imported into the hydrographic area through the Virginia City siphon, through the municipal supply system for Carson City, and through the pipeline that transmits treated effluent from Carson City to a reservoir near the Brunswick Canyon drainage (pl. 1). Water pumped from public supply wells in the Carson Plains subbasin is imported to the Mound House subbasin.

The movement of ground water is affected by the location of recharge and discharge, the degree of fracturing and weathering of consolidated rocks, and the geometry and stratigraphy of basin-fill sediments. These factors control the altitude of the water table at any given point. The direction of ground-water flow can be determined from variations in the altitude of the water table. Ground water flows at right angles to lines of equal water-level altitude.

In the Carson and Eagle Valley Hydrographic Areas and the three western subbasins of the Dayton Valley Hydrographic Area, water-level measurements at 106 wells, made mostly during December 1995, 
were used to develop lines of equal water-level altitude (pl. 3). These lines were used to estimate the direction of ground-water flow and to assess the potential for interbasin flow. Prior to this study, water-level measurements in the Riverview, Mound House, and westernmost Carson Plains subbasins were sparse. Water levels near the valley floor of the Carson Plains subbasin were measured during 1981 and remeasured at 30 wells during 1995 for this study. Water-level measurements made from 1971 to 1982 in the Stagecoach and Bull Canyon subbasins are reported by Harrill and Preissler (1994, p. H22) and are used in this study to describe ground-water movement in those subbasins.

The following sections describe the occurrence and movement of ground water near and within each subbasin. Because few wells are in consolidated rocks of the mountains, the following descriptions are limited to ground-water flow in basin-fill sediments and consolidated rocks near the valley floor. The movement of ground water in the mountain blocks is poorly understood.

\section{Riverview Subbasin}

Beneath the floor of easternmost Eagle Valley, the depth to water below land surface in December 1995 was generally less than $10 \mathrm{ft}$, increasing to almost $30 \mathrm{ft}$ beneath the north end of the valley (pl. 3). As land surface rises toward the Mound House subbasin, depth to water increased to over $100 \mathrm{ft}$. Depth to water also increased to as much as $100 \mathrm{ft}$ beneath the higher points of land near the hydrographic-area divide (wells R-7 and R-10). In the Riverview subbasin near the Carson River flood plain, depth to water was also generally less than $10 \mathrm{ft}$. East of the Carson River, depth to water increased from about $40 \mathrm{ft}$ to over $200 \mathrm{ft}$ as land surface rises toward the Pine Nut Mountains. In the Carson Valley Hydrographic Area south of the Riverview subbasin, depth to water was from 200 to about $400 \mathrm{ft}$ below land surface (pl. 3).

Near the northern part of the subbasin, waterlevel contours are approximately parallel to the boundary between the Eagle and Dayton Valley Hydrographic Areas (pl. 3). These contours indicate that ground water flows from Eagle Valley to the Riverview subbasin beneath the boundary. The flow direction changes from southward at a gradient of about $0.06 \mathrm{ft} / \mathrm{ft}$ near the northern part of the boundary, to eastward at a gradient of about $0.01 \mathrm{ft} / \mathrm{ft}$ north of Prison Hill.
East of the Carson River at wells R-11 through R-16 and R-18 (pl. 3), water levels are about the same as or less than the altitude of the Carson River. Rather than flowing toward the Carson River, ground water east of the river could flow parallel to the river, or toward the east through fractured metamorphic rocks to a downstream reach of the river in the western Mound House subbasin. This possibility is shown by the 4,590- and 4,600-ft water-level contours.

Near the southern boundary of the Riverview subbasin, water-level measurements are sparse. Water-level altitudes in the northeasternmost part of the Carson Valley Hydrographic Area are 160-270 ft higher than at well R-18 in the Riverview subbasin, suggesting a potential for subsurface flow from Carson Valley to the Riverview subbasin. However, the lack of wells for water-level measurement near the subbasin boundary makes such flow uncertain. Although the Carson River flows through a bedrock narrows from the Carson Valley Hydrographic Area to the Riverview subbasin, some subsurface flow probably moves through basin-fill sediments beneath the river channel. Glancy and Katzer, (1976, p. 51) estimate underflow to be about 15 acre-ft/yr.

Measurements of historical water-level fluctuations have been made at few wells in and near the Riverview subbasin. Water levels have been measured by the Nevada Department of Conservation and Natural Resources since the mid 1970's at two wells (R-8 and R-9, app. 2) in Eagle Valley near the Riverview subbasin, and by Carson City Utilities Department since 1990 at four wells (E-6, E-8, E-15, and E-16, app. 2) in the Riverview subbasin. Water levels at selected wells were measured periodically from February to December of 1995 for this study.

Near the northern boundary of the Riverview subbasin, water levels rose from about $5 \mathrm{ft}$ below land surface during 1975 to above land surface during 1979 when the monitoring well began to flow (well E-8, pl. 3, app. 2). This was probably in response to infiltration of water applied for irrigation of the Eagle Valley Golf Course that began during the fall of 1975.

West of the Carson River, water levels at sites R-8 and R-9 fluctuate in response to pumping at Carson City municipal supply wells (pl. 1). Two monitoring wells are installed at each site to depths of about 80 and $250 \mathrm{ft}$. During the summer months of 1994, when municipal wells were being pumped, water levels in the shallower wells declined about $1.5 \mathrm{ft}$ at site R-8 and about $4 \mathrm{ft}$ at site R-9 (app. 2). Water levels in the deeper 
monitoring wells declined about $4 \mathrm{ft}$ at site R- 8 and about $20 \mathrm{ft}$ at site R-9. During winter months, municipal pumping decreases and water levels rise. No longterm net decline was measured from 1990 to 1994.

Water-level fluctuations near the subbasin boundary influence the hydraulic gradient and the volume of subsurface flow across the boundary. Continued monitoring of water levels will allow estimation of how the volume of subsurface flow entering the Riverview subbasin from the Eagle Valley Hydrographic Area changes with time.

During 1995, water levels declined about 4-6 ft at wells R-3 and R-4 near the west bank of the Carson River from July to September as stream stage declined about $7 \mathrm{ft}$ (app. 2). East of the Carson River, water levels rose about $1 \mathrm{ft}$ from July to December at wells $\mathrm{R}-12$ through $\mathrm{R}-16$, probably in response to decreases in pumping at each individual well from summer to early winter.

\section{Mound House Subbasin}

Depth to water during December 1995 was about $160 \mathrm{ft}$ near the western subbasin boundary, and was about 270 to almost $300 \mathrm{ft}$ in volcanic rocks between the Carson River and the western subbasin boundary. Depth to water in basin-fill sediments was about $70 \mathrm{ft}$ below land surface north of U.S. Highway 50, decreasing to about $30 \mathrm{ft}$ below land surface south of the highway. No wells are in the area between the valley floor of the Mound House subbasin and the Carson River, the area south of the river, or the area along the boundary between the Eagle Valley Hydrographic Area and the northwestern part of the Mound House subbasin. Thus, little is known about depth to water or groundwater movement in those parts of the Mound House subbasin.

Water-level contours (pl. 3) show a gradient to the southeast at about $0.05 \mathrm{ft} / \mathrm{ft}$ north of U.S. Highway 50 , decreasing to about $0.02 \mathrm{ft} / \mathrm{ft}$ south of the highway in basin-fill sediments. Where wells are available for adequate control, water-level contours cross the hydrographic-area and subbasin boundaries at approximately right angles. This suggests that ground-water flow across these boundaries is minor. However, the lack of wells near the easternmost side of the subbasin north of the Carson River makes this conclusion tenuous.
Water-level altitudes between the valley floor of the Mound House subbasin and the Carson River are not known, but can be inferred by the location of springs and dry stream beds. Where springs flow, the water-level altitude must be equal to, or slightly higher than, land-surface altitude. Where stream beds are dry, the water-level altitude must be less than the landsurface altitude. The locations of springs and dry stream channels were used as controls to draw the dashed water-level contours shown on plate 3 . South of U.S. Highway 50, springflow is found at an altitude of about $4,700 \mathrm{ft}$ (pl. 3). Other stream beds east of this location are dry.

The direction of ground-water flow shown by the water-level contours on plate 3 suggests that ground-water flow is toward the Carson River from the northern part of the Mound House subbasin. However, seepage measurements made at periods of low flow show that the river reach through the Mound House subbasin is losing streamflow (table 4). This fact, and the greater depth to water in wells screened in volcanic rocks compared to those screened in basin-fill sediments, suggests that ground water in basin-fill sediments may be perched above or poorly connected with a deeper water table in underlying volcanic rocks. Perched water tables develop when zones of low permeability inhibit downward movement of water and an unsaturated zone develops between the perched ground water and the water table. Installation of wells through the basin-fill sediments and into the underlying volcanic rocks would confirm this hypothesis. Wells installed between the valley floor and the Carson River would allow more accurate measurement of the gradient within volcanic rocks north of the Carson River.

Water-level fluctuations in the Mound House subbasin have been measured only at municipal supply wells by Dayton Utilities. However, because these wells are being pumped much of the time, the water levels measured at various times after the wells are turned off are mostly an indication of the rate of recovery at each individual well and do not supply information on regional water-level fluctuations. Water levels measured for this study in and near the subbasin showed little fluctuation from July to December 1995 (app. 2). Water levels rose in some wells (E-1, M-13, $\mathrm{M}-7$, and $\mathrm{M}-8$ ), probably in response to decreased pumping of the wells from summer to winter months. Continued monitoring of water levels would show if existing pumping is causing net water-level declines. 


\section{Carson Plains Subbasin}

Depth to water measured in wells is greatest in the western part of the subbasin. Static water levels measured in wells that supply Mound House within the Carson Plains subbasin and in the mountain block of the Virginia Range range from 100 to more than $200 \mathrm{ft}$ below land surface (wells C-1 and C-2, pl. 3). Depth to water decreases from about $130 \mathrm{ft}$ northeast of the boundary between the Mound House and Carson Plains subbasins, to about $30 \mathrm{ft}$ near the junction of Nevada Highway 341 and U.S. 50. Around the perimeter of the valley floor, depth to water is about $270 \mathrm{ft}$ west of Dayton (well C-12), over $200 \mathrm{ft}$ in the northernmost part of the valley (well C-46), and over $100 \mathrm{ft}$ south of the Carson River (well C-21). Depth to water in alluvial sediments at the base of the Pine Nut Mountains and at the mouth of Eldorado Canyon is unknown. Depth to water decreases to about 50 to $60 \mathrm{ft}$ near the center of the subbasin. Close to the Carson River, depth to water is less than $20 \mathrm{ft}$.

Water-level contours shown on plate 3 indicate that ground water flows from west to east through basin-fill sediments in the westernmost part of the subbasin. The hydraulic gradient decreases from about $0.06 \mathrm{ft} / \mathrm{ft}$ to about $0.02 \mathrm{ft} / \mathrm{ft}$ near the intersection of Nevada State Route 341 and U.S. Highway 50, then increases to about $0.03 \mathrm{ft} / \mathrm{ft}$ between the intersection and the valley floor near Dayton. On the valley floor, ground water flows to the northeast, parallel to the Carson River, at very low gradients ranging from 0.005 $\mathrm{ft} / \mathrm{ft}$ near Dayton to $0.001 \mathrm{ft} / \mathrm{ft}$ near the eastern side of the subbasin. The low gradients and the presence of highly productive wells in the valley suggest that aquifers beneath the valley floor are highly permeable.

South of the Carson River, springs are at an altitude of about 4,960 $\mathrm{ft}$ in alluvial sediments at the base of the Pine Nut Mountains. If the springs represent the altitude of the water table, a steep gradient of about $0.05 \mathrm{ft} / \mathrm{ft}$ exists toward the valley floor. However, the springs could be flowing from a perched water table. Because the alluvial sediments probably have a relatively high permeability, and if the saturated thickness of the sediments is large, the steep gradient suggests that ground-water inflow from the base of the Pine Nut Mountains and the mouth of Eldorado Canyon could be large. Installation of additional wells would show whether the springs emanate from perched ground water, and would allow an assessment of the volume of subsurface flow toward the valley floor.
Steep gradients of 0.17 to $0.09 \mathrm{ft} / \mathrm{ft}$ are also indicated by water levels in consolidated rocks along SixMile Canyon. Here, the steep gradient is probably a result of the relatively low permeability of the consolidated rocks as a whole. The gradient between water levels in consolidated rocks and basin-fill sediments near the mouth of Six-Mile Canyon is about $0.05 \mathrm{ft} / \mathrm{ft}$. The large difference in gradients measured in consolidated rocks and basin-fill sediments suggests that basin-fill sediments are much more permeable than the consolidated rocks in the mountain blocks.

As of 1995, water levels in the eastern part of the Carson Plains subbasin are about $30 \mathrm{ft}$ higher than those in the western part of the Stagecoach subbasin (pl. 3). Harrill and Preissler (1994, p. H10) show that, prior to 1971, water levels in the western part of the Stagecoach subbasin were at an altitude of about 4,255 $\mathrm{ft}$, or about $15 \mathrm{ft}$ lower than those in the eastern part of Carson Plains. Ground-water withdrawals in Stagecoach since 1971 have caused water levels to decline, increasing the hydraulic gradient between the two subbasins. Thus, ground water may flow through consolidated rocks that form the topographic divide. Granitic rocks underlie the northernmost part of the divide, whereas andesitic and basaltic volcanic rocks form the southern part of the divide (pl. 2). The volcanic rocks are considered permeable to ground-water flow between the Stagecoach subbasin and the Carson River (Harrill and Preissler, 1994, p. H11; Harrill and others, 1993, p. 181). If so, ground water could flow from the Carson Plains to the Stagecoach subbasin.

Thomas and Lawrence (1994, p. 16) present data showing that the deuterium composition of ground water on the western side of the Stagecoach subbasin could result from a mixture of ground water from two areas in the Carson Plains subbasin. Two well waters sampled on the eastern side of the Carson Plains subbasin have compositions that, if mixed, would result in a composition similar to that sampled from a well on the western side of the Stagecoach subbasin. Although not conclusive evidence, the data do not preclude subsurface flow from Carson Plains to the Stagecoach subbasin.

Seasonal, annual, and long-term water-level fluctuations in the Carson Plains subbasin are generally less than $10 \mathrm{ft}$ (fig. 3A). Fluctuations have been measured periodically near the center of the valley floor since about 1975 at well C-34. There, water levels 

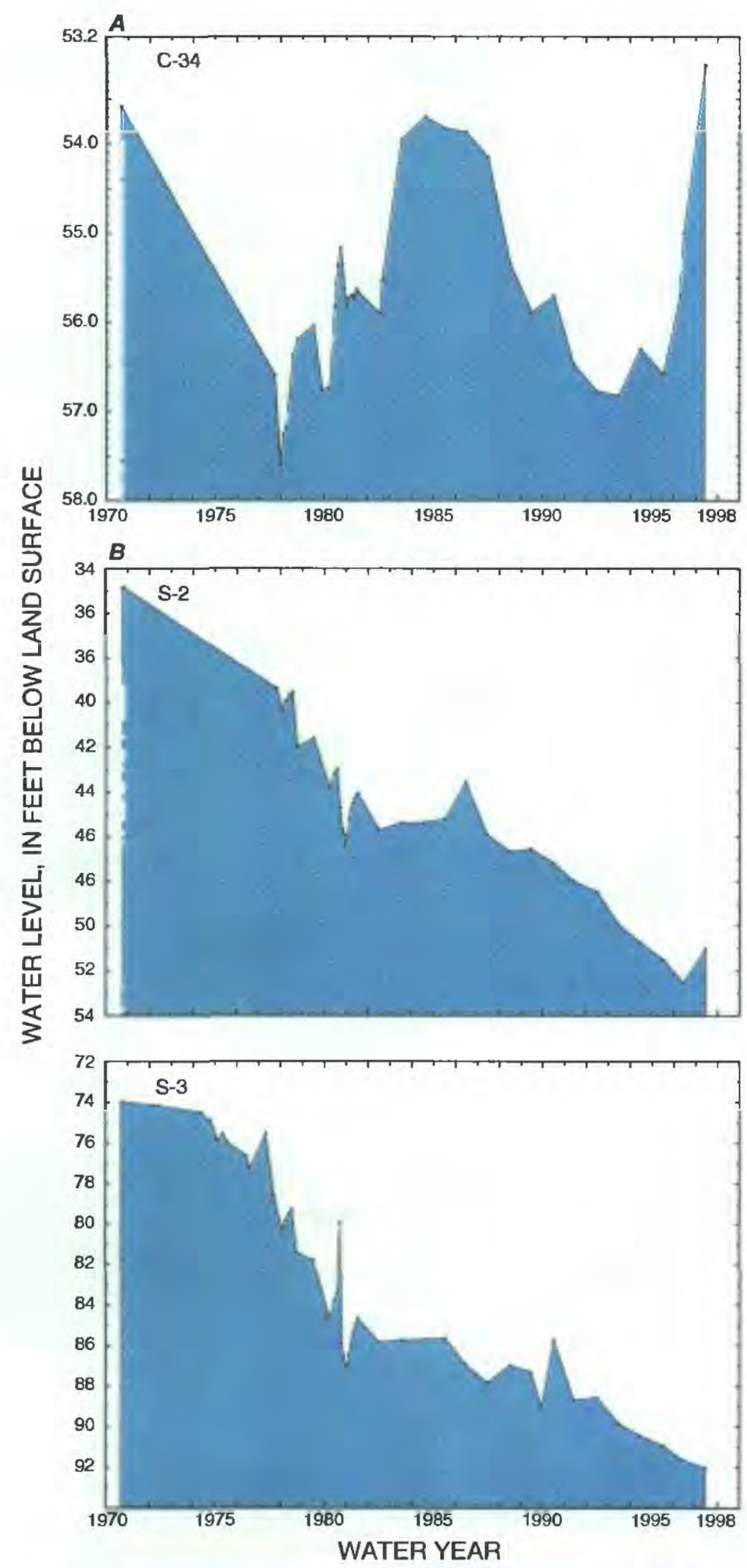

Figure 3. Historical water-level fluctuations in selected wells in $(A)$ the Carson Plains subbasin and $(B)$ Stagecoach subbasin. Well locations are shown on plate 3 . Dashes indicate no measurements made.

declined about $3 \mathrm{ft}$ from the wet years of 1969 and 1970 to 1976 , rose about $3 \mathrm{ft}$ during the wet years of the early-1980's, and declined the same amount from 1986 to 1993 (fig. 3A).
The magnitude of long-term water-level changes at 30 wells is shown by measurements made during July 1981, August 1995, and November or December 1995 for this study (pl. 3). Prior to measurements during 1980 , annual precipitation had been either about normal or below normal for 10 years, was well above normal during 1980, and was below normal during 1981. Prior to measurements during 1995, annual precipitation had been well below normal for about 8 years and well above normal during the winter of 1995 (fig. 2). Some of the water-level changes at the 30 sites could be affected by the amount of water withdrawn from the well and the length of time since the well had been last pumped. Also, some wells not in use during 1981 were being used during 1995, and vice versa (app. 2).

Water levels at most wells were lower by less than $5 \mathrm{ft}$ during August 1995 than they were during July 1981. Well C-22 is near a supply well that was pumped for irrigation of crops in 1981 and for irrigation of the Dayton Valley Golf Course in 1995. The water level was about $12 \mathrm{ft}$ lower in August 1995 than it was in 1981. At well C-25, water was pumped for irrigation of crops in 1981 but had not been in use for several years prior to 1995. The water level at C-25 was about $6 \mathrm{ft}$ lower in August 1995 than during 1981. Lower water levels in 1995 than in 1981 could be caused by drier conditions prior to 1995 or, at some wells (C-20, C-21, C-22, pl. 3, app. 2), increased nearby pumping.

From August 1995 to November or December 1995, water levels at many wells rose from 2 to $5 \mathrm{ft}$. The higher water levels in late fall and early winter could be caused by a decrease in pumping from summer months, or recharge from the above-normal precipitation in late 1995, that moved through the groundwater system from the mountains to the valley floor. Some wells that were not pumped in 1995 showed little water-level rise (C-21, C-23, and C-33), whereas others rose (C-25, C-26, C-49). Thus, the cause of the measured water-level rises is difficult to determine.

Water levels at wells C-20, C-21, and C-22 remained 3-8 ft lower in November-December 1995 than in 1981. This could indicate declining water levels over a small area, probably less than $2 \mathrm{mi}^{2}$, caused by nearby pumping. Additional wells and water-level measurements would show whether water levels are declining and, if so, the extent of the decline. 


\section{Stagecoach Subbasin}

Depth to water in the Stagecoach subbasin is greater than $200 \mathrm{ft}$ below land surface beneath the northern part of the valley floor and near the northeastern hydrographic-area boundary along U.S. Highway 50 (Harrill and Preissler, 1994, p. H9). Prior to 1971 , depth to water was less than $30 \mathrm{ft}$ near the center of the valley floor about $1 \mathrm{mi}$ south of U.S. Highway 50. Ground-water withdrawals resulted in a water-level decline of about $10 \mathrm{ft}$ in this area, from 1971 to 1982 (Harrill and Preissler, 1994, p. H23). Maximum waterlevel declines from 15 to almost $20 \mathrm{ft}$ were measured near municipal wells about 1 mi north of U.S. Highway 50. Along the southeastern subbasin boundary, depth to water is about $50 \mathrm{ft}$.

Water-level contours presented by Harrill and Preissler (1994, p. H22) for spring 1982 show gradients of about $0.008 \mathrm{ft} / \mathrm{ft}$ toward the southeast beneath the northern part of the valley floor and about 0.001 toward the northeast beneath the western part of the valley floor. Near the northeastern hydrographic-area boundary, along U.S. 50, a gradient of about $0.005 \mathrm{ft} / \mathrm{ft}$ exists toward Churchill Valley. To the southeast, between the valley floor and the Carson River, the gradient is very flat, about $0.0003 \mathrm{ft} / \mathrm{ft}$, toward the river.

Results obtained from a numerical ground-water flow model of Stagecoach Valley (Harrill and Preissler, 1994 , p. H41) indicate that, in 1982, inflow from the Carson River and the Bull Canyon subbasin across the southwestern boundary of the Stagecoach subbasin was about 300 acre-ft/yr, outflow towards Churchill Valley was about 160 acre-ft/yr, and net outflow to the Carson River across the southeastern subbasin boundary was about 30 acre- $\mathrm{ft} / \mathrm{yr}$. Inflow from the Carson Plains subbasin was not considered during modelling. The model showed that from 1971 to 1982 , groundwater pumping increased inflow from the Carson River and Bull Canyon subbasin by about 20 acre-ft/yr, decreased outflow to Churchill Valley by about 10 acre-ft/yr, and decreased the net outflow to the Carson River to about 10 acre-ft/yr. The net effect of pumping on flow of the Carson River was a decrease of 40 acre$\mathrm{ft} / \mathrm{yr}$, which is about $0.05 \mathrm{ft}^{3} / \mathrm{s}$, or about 0.0001 percent of the average annual flow.

From 1982 to 1994 , water levels in the Stagecoach subbasin at 12 long-term monitoring wells declined from 2 to as much as $10 \mathrm{ft}$ (Frisbie and others, 1983 , p. 342-345, Clary and others, 1995, p. 586-587). Water levels can be seen to fluctuate seasonally from 1 to $4 \mathrm{ft}$ when frequent measurements are made (fig. 3B). At wells S-2 and S-3, water levels did not decline as rapidly during the wet years $1982-86$ as during the following dry years 1987-94.

\section{Bull Canyon Subbasin}

The depth to water measured in the Bull Canyon subbasin in basin-fill sediments ranges from $60 \mathrm{ft}$ south of the Carson River (well BC-1, pl. 3) to less than $30 \mathrm{ft}$ near the river (Harrill and Preissler, 1994, p. H9).

Water-levels measured for this study (app. 2) and those presented by Harrill and Preissler (1994, p. H22) indicate a gradient parallel to the river of about $0.002 \mathrm{ft} / \mathrm{ft}$ in basin-fill sediments near both the western and eastern subbasin boundaries. Depth to ground water and the direction of ground-water flow in consolidated rocks south of the river are unknown.

As discussed previously, ground water flows into the Bull Canyon subbasin from the Carson Plains subbasin through basin-fill sediments beneath the river. Ground water flows out of the subbasin to the southwest part of the Stagecoach subbasin through volcanic rocks and into the subbasin from the southern part of the Stagecoach subbasin through basin-fill sediments. In addition, ground-water flow through basin-fill sediments beneath the Carson River channel to the Churchill Valley Hydrographic Area is estimated to be about 70 acre-ft/yr (Glancy and Katzer, 1976, p. 51).

\section{METHODS USED TO ESTIMATE RECHARGE, DISCHARGE, AND SUBSURFACE FLOW}

Ground water in the Dayton Valley Hydrographic Area can be supplied by recharge from infiltration of precipitation, streamflow, imported water, water applied for irrigation (including lawn watering), or water from septic systems or municipal wastetreatment plants. Water infiltrating from irrigation and septic systems or municipal waste-treatment plants is often called secondary recharge if the water was originally derived from ground-water pumping (Harrill, 1973, p. 62). Discharge from the ground-water system takes place by pumping, seepage to the Carson River, evapotranspiration (including evaporation from bare soil and transpiration by plants), or by crop consumptive use.

Ground water in basin-fill sediments and consolidated rocks can flow between hydrographic areas and subbasins where their boundaries are not ground-water 
divides. Such flow is commonly called subsurface flow (Glancy and Katzer, 1976, p. 51). Because recharge and discharge are commonly defined as flow into or out of the saturated zone of an aquifer (Freeze and Cherry, 1979, p. 211), subsurface flow from one basin to another is not strictly considered recharge or discharge. Subsurface flow into or out of the hydrographic area or subbasins is combined with estimates of recharge and discharge to obtain total inflow or outflow for each area.

The methods used to obtain estimates for individual water-budget components are discussed below. The estimated budgets for each subbasin and for the entire Dayton Valley Hydrographic Area follow.

\section{Recharge}

Recharge from infiltration of precipitation has been estimated for many basins in Nevada using the Maxey-Eakin method (Watson and others, 1976). The Maxey-Eakin method was initially developed for 13 basins in east-central Nevada (Maxey and Eakin, 1949, p. 40). The method was developed by trial and error; different recharge percentages were assigned for each of the major precipitation zones on the annual precipitation map of Hardman (1936; Hardman and Mason, 1949, p. 10) until total recharge matched the estimated discharge in each of the 13 basins. Thus, the method assumed that the basins used in the analysis were in hydrologic equilibrium and that average annual recharge equaled average annual discharge. The final percentages obtained were: zero recharge where annual precipitation is less than 8 in. (generally the valley floors), 3 percent from 8 to 12 in., 7 percent from 12 to 15 in., 15 percent from 15 to 20 in., and 25 percent for areas receiving over $20 \mathrm{in}$. of precipitation (Maxey and Eakin, 1949, p. 40). The method was later modified (Eakin, 1960, p. 12) by relating precipitation to altitude, and using altitude zones in place of the original precipitation zones from the Hardman map. Although empirical in nature, with uncertainty as to how accurate the method might be for basins other than those for which it was developed, the Maxey-Eakin method has been used to estimate recharge to over 200 basins in Nevada (Watson and others, 1976, p. 335).

Unknown amounts of uncertainty or inaccuracy are inherent in the application of the Maxey-Eakin method and the resulting estimates of recharge. Uncertainties in the method are inherent because the uncertainty or accuracy of the estimates of discharge, upon which the recharge estimates are based, is unknown. Also, an alternative set of recharge percentages could be used to derive a balance between recharge an discharge. However, workers attempting to do so concluded that the uncertainty associated with an alternative set of percentages is probably as great as with the original percentages, and both provide only a first approximation of actual recharge (Watson and others, 1976, p. 347).

Descriptions of the Maxey-Eakin method do not clearly state that recharge from infiltration of runoff is included in the estimate of recharge. Inclusion of recharge from runoff is implied when Eakin and Maxey (1951, p. 81) justify a larger amount of recharge to Ruby Valley, Nev., than to basins of similar size because the steep slopes in the basin "favor a high percentage of runoff to the area of recharge." This further implies that recharge estimated from within each precipitation zone does not necessarily take place within the geographic location of the zone. Because of this, and because the method was developed for entire basins, the accuracy of the method when applied to smaller portions of a basin is also uncertain.

In addition, the accuracy of the method is uncertain when applied to precipitation distributions different than those for which the method was developed (the Hardman map) or basins where the valley floor receives more than 8 in. of annual precipitation. In basins near the Sierra Nevada, where precipitation is greater than in eastern Nevada, the original recharge percentages have been adjusted to account for greater precipitation (Glancy and Katzer, 1976, p. 48). Recent work in western Eagle Valley has shown that estimates of subsurface flow beneath three drainage basins, combined with estimates of streamflow infiltration from each drainage basin, are in general agreement with recharge calculated using the Maxey-Eakin method and a precipitation distribution different from the 1936 Hardman map, except where bedrock beneath the drainage basin is exceptionally permeable (Maurer and others, 1996, p. 33). Although not conclusive, this work suggests that, in at least some places, the Maxey-Eakin method may produce reasonable estimates of recharge for individual drainage basins of a hydrographic area and for precipitation distributions different from those used to develop the method.

Recent work by Nichols (1994, p. 3268) suggests that rates of ground-water discharge by phreatophytes measured in northern and central Nevada could be up to five times greater than the estimates used to develop 
the Maxey-Eakin method. Because the original recharge percentages were based on estimates of discharge that may have been too low, more water may be moving through the hydrologic system than previously thought. Thus, recharge calculated by applying the Maxey-Eakin percentages to precipitation amounts greater than those used to develop the method could still be reasonable.

Despite the limitations and uncertainties in using the Maxey-Eakin method, no other method has been developed to estimate recharge from precipitation that falls within the study area. The method is also the most reasonable tool available to apportion recharge to individual subbasins within the hydrographic area and to allow comparison with water budgets determined in the reconnaissance report by Glancy and Katzer (1976). In this report, recharge estimated by the Maxey-Eakin method is assumed to include recharge from infiltration of precipitation and streamflow generated within the hydrographic area or subbasin.

Using the distance-altitude relation and the 1996 Nevada Precipitation map, annual precipitation in the Dayton Valley Hydrographic Area has been shown to be potentially about 40 percent greater than that estimated using the precipitation-altitude relation presented by Glancy and Katzer (1976, p. 48) (table 2). Applying the Maxey-Eakin method to all three estimates of mean annual precipitation provides a range of possible estimates to be compared with discharge estimates. Also, using three different precipitation distributions allows evaluation of the sensitivity of the method to the distribution of precipitation. To be consistent with the reconnaissance study by Glancy and Katzer (1976), the percentage of recharge for areas receiving more than $20 \mathrm{in}$. of annual precipitation is assumed to be 20 , rather than 25 percent (table 6 ).

Streamflow that infiltrates from the Carson River in the hydrographic area is considered to be an additional source of recharge. Average losses to ground water from the Carson River simulated over a 10-year period using a streamflow model (Hess, 1996) are used to estimate average annual recharge from infiltration of streamflow of the Carson River (Glen W. Hess, U.S. Geological Survey, written commun., 1996) (table 4).

Infiltration of imported water and secondary recharge is also considered an additional source of recharge. Estimates of recharge from imported water are made using the same assumptions used to estimate secondary recharge. Estimates of secondary recharge from irrigation of lawns or crops and from septic tanks
Table 6. Estimated recharge for (A) Dayton Valley Hydrographic Area and (B) subbasins, using three different precipitation distributions. Summarized from appendix 1

[Abbreviations: acre-ft/yr, acre-feet per year; in/yr, inches per year]

\section{A. Recharge to Dayton Valley Hydrographic Area}

\begin{tabular}{|c|c|c|c|}
\hline $\begin{array}{c}\text { Precipitation } \\
\text { range } \\
\text { (in/yr) }\end{array}$ & $\begin{array}{c}\text { Estimated } \\
\text { precipitation } \\
\text { (acre-ft/yr) }\end{array}$ & $\begin{array}{l}\text { Percent } \\
\text { recharge }\end{array}$ & $\begin{array}{c}\text { Estimated } \\
\text { recharge } \\
\text { (acre-ft/yr) }\end{array}$ \\
\hline \multicolumn{4}{|c|}{$\begin{array}{l}\text { Altitude-precipitation relation of Glancy and Katzer } \\
(1976, \text { p. 48), using digital elevation model }\end{array}$} \\
\hline$>20$ & 1,400 & 20 & 280 \\
\hline $15-20$ & 16,000 & 15 & 2,400 \\
\hline $12-15$ & 48,000 & 7 & 3,400 \\
\hline $8-12$ & 59,000 & 3 & 1,800 \\
\hline$<8$ & 53,000 & minor & 0 \\
\hline Total (rounded) . . & 180,000 & & 7,900 \\
\hline \multicolumn{4}{|c|}{ Distance-altitude relation } \\
\hline$>20$ & 300 & 20 & 60 \\
\hline $15-20$ & 27,000 & 15 & 4,100 \\
\hline $12-15$ & 56,000 & 7 & 3,900 \\
\hline $8-12$ & 83,000 & 3 & 2,500 \\
\hline$<8$ & 37,000 & minor & 0 \\
\hline Total (rounded) & 200,000 & & 11,000 \\
\hline \multicolumn{4}{|c|}{1996 Nevada precipitation map } \\
\hline$<20$ & 53,000 & 20 & 11,000 \\
\hline $15-20$ & 69,000 & 15 & 10,000 \\
\hline $12-15$ & 46,000 & 7 & 3,200 \\
\hline $8-12$ & 62,000 & 3 & 1,900 \\
\hline$<8$ & 21,000 & minor & 0 \\
\hline Total (rounded) .. & 250,000 & & 26,000 \\
\hline
\end{tabular}

\section{B. Recharge to individual subbasins}

\begin{tabular}{|c|c|c|c|}
\hline Subbasin & $\begin{array}{c}\text { Altitude- } \\
\text { precipitation } \\
\text { relation of } \\
\text { Glancy and } \\
\text { Katzer }{ }^{1} \text { using } \\
\text { digital elevation } \\
\text { model (1976, } \\
\text { p. 48) }\end{array}$ & $\begin{array}{c}\text { Distance- } \\
\text { altitude } \\
\text { relation }\end{array}$ & $\begin{array}{c}1996 \\
\text { Nevada } \\
\text { precipitation } \\
\text { map }\end{array}$ \\
\hline
\end{tabular}

\begin{tabular}{|c|c|c|c|}
\hline \multicolumn{4}{|c|}{ Recharge estimated from precipitation distribution (acre-ft/yr) } \\
\hline Riverview & 250 & 440 & 1,500 \\
\hline Mound House & 720 & 1,100 & 3,000 \\
\hline Carson Plains. ... & 5,100 & 6,800 & 16,000 \\
\hline Stagecoach ..... & 560 & 800 & 1,500 \\
\hline Bull Canyon .... & 1,200 & 1,400 & 3,700 \\
\hline Total (rounded). . . & 7,800 & 11,000 & 26,000 \\
\hline
\end{tabular}


have been made but are based on little data. Harrill (1973, p. 62) estimated that 20 percent of water used for lawn watering in a valley north of Reno became recharge. Harrill and Preissler (1994, p. H41) estimated that 16 percent of the water pumped for crop irrigation returned to the ground-water system in the Stagecoach subbasin. Harrill and Moore (1970, p. 70) estimated that secondary recharge from irrigation in Paradise Valley, Nev., averaged 40 percent. In this report, 20 percent of water pumped for domestic use and 20-40 percent of water pumped for agricultural use is assumed to become secondary recharge from irrigation of lawns or crops (table 7).

Probably most of the water entering the subsurface from septic systems becomes recharge. Data from sewage-treatment plants in the Dayton Valley Hydrographic Area indicate that discharge to the plants averages about 0.15 acre-ft/yr per home (James Williams, Nevada Department of Environmental Protection, written commun., 1995; Don Allen, Dayton Utilities, oral commun., 1995; and Barbara Bowers, Virginia City Water Co., oral commun., 1995). This value was used to estimate secondary recharge from septic tanks. The number of septic tanks in an area was determined by the number of houses counted on aerial photographs taken in 1994, in areas where municipal sewage treatment is not available. The volumes of effluent discharged by municipal treatment plants are available from the Nevada Department of Environmental Protection (James Williams, written commun., 1995). An estimate of the portion that becomes recharge was made, depending on the method of effluent disposal (table 7).

\section{Discharge}

Volumes of ground water pumped for municipal and industrial use are available from the records of the various utilities which supply the water and records of the Nevada State Engineer (table 8). Most water pumped for industrial use is supplied by municipal wells, except for a small amount pumped by a mine in the Carson Plains subbasin (table 8). Thus, in this report, ground water pumped for industrial use is included in the estimate of municipal pumping.

Estimates of domestic pumping are based on an annual use rate per home and the number of houses counted on aerial photographs taken in 1994 in areas where municipal water supply is not available. An annual rate of 0.5 acre-ft/yr per home was used to estimate domestic pumping (table 8). This is the average volume of water supplied to homes by municipal water systems in the Dayton Valley Hydrographic Area on the basis of data from the Carson City Utilities Department (Dorothy Timian-Palmer, oral commun., 1995); Dayton Utilities (Don Allen, written commun., 1995), Stagecoach General Improvement District (Lynne Arndell, written commun., 1995), and the Nevada Division of Water Resources (Kim Gronewald, written commun., 1995).

Agricultural pumping is mainly in the Carson Plains and Stagecoach subbasins. Estimates of agricultural pumping in the Carson Plains and Stagecoach subbasin are available from the Nevada Division of Water Resources (Tracy Taylor and Stephen Walmsley, written commun., 1983) and Harrill and Preissler (1994, p. H20), respectively, for the early 1980's (table 8 ). Estimates made by the Nevada Division of Water Resources were obtained by multiplying water-righted acreage by a 4 acre-ft/yr use rate and dividing by two, assuming that pumps were used, on average, for half the irrigation season in average-to-dry years. Estimates of agricultural pumping in the Carson Plains subbasin were updated by not including pumping estimated by the Nevada Division of Water Resources for irrigated land taken out of production from 1983 to 1994 (pl. 1). Aerial photography suggests that the amount of land irrigated in the Stagecoach subbasin has changed little as of 1994.

Seepage measurements suggest that groundwater is discharged to the Carson River mainly in the Carson Plains subbasin. Simulations of Carson River streamflow are used to estimate the quantity of discharge (Glenn W. Hess, U.S. Geological Survey, written and oral commun., 1996).

Discharge by phreatophytes and consumptive use by crops is estimated by applying a range in rates of use to the area covered by phreatophytes and irrigated crops (table 9). These areas were determined from mapping done by Glancy and Katzer (1976, pl. 1), who delineated the combined area of phreatophytes and irrigated land along the Carson River. For this study, small additional areas of phreatophytes were mapped near Mound House, and aerial photography taken in 1994 was used to delineate irrigated lands near the river. Mapped areas were digitized and acreages were determined by computer.

Glancy and Katzer (1976, p. 63) estimated the area covered by phreatophytes (6,700 acres) by subtracting the area of irrigated crops reported in 1974 by 
Table 7. Sources and estimates of secondary recharge to subbasins of Dayton Valley Hydrographic Area, Nevada, 1994

[Abbreviation: acre-ft/yr, acre-feet per year. Symbol: --, minor or zero]

\begin{tabular}{|c|c|c|c|c|c|c|}
\hline \multirow[b]{2}{*}{ Subbasin } & \multirow{2}{*}{$\begin{array}{c}\text { Estimated } \\
\text { number of } \\
\text { septic } \\
\text { systems }^{1}\end{array}$} & \multicolumn{5}{|c|}{ Estimated secondary recharge (acre-ft/yr) } \\
\hline & & Septic systems ${ }^{2}$ & $\begin{array}{c}\text { Lawn } \\
\text { watering }\end{array}$ & Effluent ${ }^{3}$ & $\begin{array}{c}\text { Ground } \\
\text { water pumped } \\
\text { for irrigation }\end{array}$ & $\begin{array}{c}\text { Total } \\
\text { (rounded) }\end{array}$ \\
\hline Riverview & 150 & 20 & ${ }^{4} 50$ & ${ }^{5} 100$ & -- & 170 \\
\hline Mound House .. & 520 & 80 & ${ }^{6} 40$ & $\begin{array}{r}30 \\
7300\end{array}$ & -- & 450 \\
\hline Carson Plains. . . & 1,300 & 200 & ${ }^{8} 480$ & ${ }^{9} 240$ & ${ }^{10} 500-1,000$ & $1,400-1,900$ \\
\hline Stagecoach..... & 510 & 75 & ${ }^{11} 60$ & -- & ${ }^{12} 150$ & 280 \\
\hline Bull Canyon. . & 10 & 1 & ${ }^{13} 1$ & -- & ${ }^{14} 10-20$ & $20-30$ \\
\hline Total (rounded) . & 2,500 & 380 & 630 & 670 & $660-1,200$ & $2,300-2,800$ \\
\hline
\end{tabular}

\footnotetext{
${ }^{1}$ Estimated from house count determined from aerial photography taken in 1994 and number of customers on municipal sewer systems. Number of municipal customers from Dayton Utilities (Don Allen, oral commun., 1995) and Virginia City Water Company (Barbara Bowers, oral commun., 1995).

${ }^{2}$ Estimated to be 0.15 acre-ft/yr/system.

${ }^{3}$ Estimated from volume of effluent treated by municipal plants. Data from James Williams, Nevada Department of Environmental Protection, written commun., 1995.

${ }^{4}$ Estimated to be 20 percent of the combination: domestic use of 75 acre-ft/yr and 165 acre-ft/yr used by 330 municipal customers supplied by Carson City (table 8 ). Number of users determined from aerial photography taken in 1994.

${ }^{5}$ Estimated to be 20 percent of 500 acre-ft/yr of effluent historically imported from Carson City for crop irrigation on land recently (1995) converted to golf course.

${ }^{6}$ Estimated to be 20 percent of the combination: 165 acre-ft/yr for municipal use ( 160 acre- $\mathrm{ft} / \mathrm{yr}$ imported from Carson Plains subbasin), and 50 acre- $\mathrm{ft} / \mathrm{yr}$ for domestic use (table 8 ).

${ }^{7}$ Recharge from effluent-holding reservoir near Brunswick Canyon estimated as difference between inflow from surface-water runoff plus precipitation on reservoir surface (1,100 acre-ft/yr) (Gary Hoffman, Carson City Waste Treatment Plant, oral commun., 1996) and estimated discharge by evaporation from reservoir surface (100 acre-ft/yr) and estimated evapotranspiration from vegetation near seep areas (700 acre-ft/yr).

${ }^{8}$ Estimated to be 20 percent of the combination: 930 acre-ft/yr for municipal use by Dayton Utilities customers, 220 acre-ft/yr imported for municipal use by Virginia City Water Company customers, $390 \mathrm{acre}-\mathrm{ft} / \mathrm{yr}$ for domestic use, and $840 \mathrm{acre}-\mathrm{ft} / \mathrm{yr}$ used for irrigation of Dayton Valley Golf Course (table 8).

${ }^{9}$ Estimated from 2.8 acre-ft/yr from Gold Hill plant, 100-percent recharge; 63 acre-ft/yr from Six-Mile Canyon plant, 50-percent recharge; $30 \mathrm{acre}-\mathrm{ft} / \mathrm{yr}$ from Rose Peak plant, less 4 acre-ft/yr evaporation; and $180 \mathrm{acre}-\mathrm{ft} / \mathrm{yr}$ from Dayton plant, less $4 \mathrm{acre}-\mathrm{ft} / \mathrm{yr}$ evaporation. Evaporation estimated to be $5 \mathrm{ft} / \mathrm{yr}$ from $250,000 \mathrm{ft}^{2}$ of surface area at both Rose Peak and Dayton plants.

${ }^{10}$ Estimated to be $20-40$ percent of 2,500 acre-ft/yr agricultural use (table 8 ).

${ }^{11}$ Estimated to be 20 percent of 290 acre-ft/yr municipal and domestic use (table 8).

${ }^{12}$ From Harrill and Preissler (1994, p. H42).

${ }^{13}$ Estimated to be 20 percent of 5 acre-ft/yr domestic use (table 8).

${ }^{14}$ Estimated to be $20-40$ percent of 60 acre-ft/yr agricultural use (table 8 ).
} 
Table 8. Ground-water withdrawals from subbasins of Dayton Valley Hydrographic Area, Nevada, 1994

[Abbreviation: acre-ft/yr, acre-feet per year. Symbol: --, indicates minor or zero]

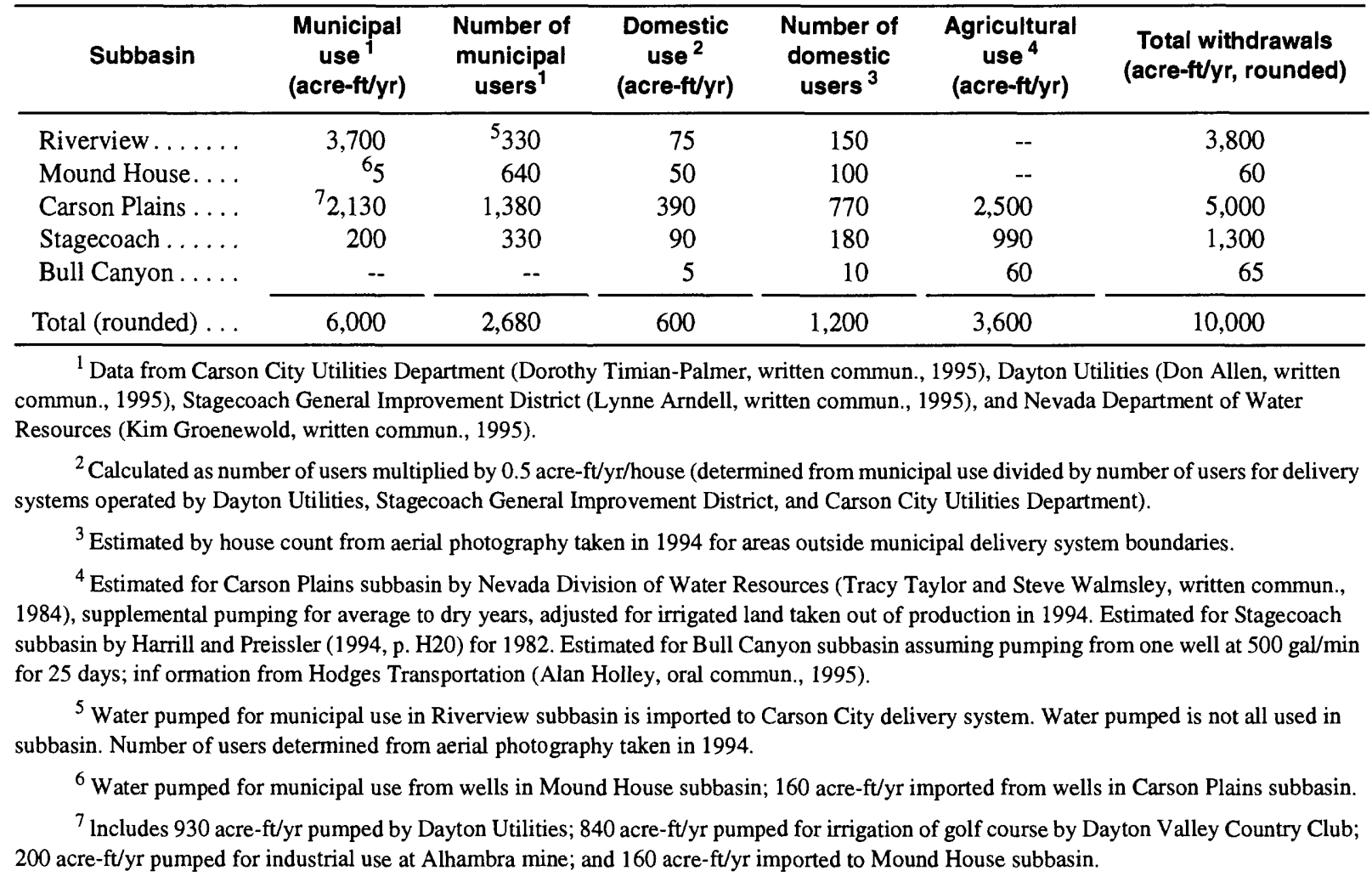

the U.S. Soil Conservation Service (6,300 acres), from the total area covered by both crops and phreatophytes $(13,000$ acres). Areas determined for the present study are 3,400 acres of irrigated crops and 8,400 acres of phreatophytes (table 9) for a total area of about 12,000 acres. About 900 acres of phreatophytes mapped by Glancy and Katzer (1976, p. 63) have been replaced by development (see pl. 1 for areas of development overlying areas of phreatophytes). The area of irrigated crops, 3,400 acres, is similar to a new estimate by the U.S. Soil Conservation Service, 4,000 acres (Richard Franklin, written and oral commun., 1995). The U.S. Soil Conservation Service (Richard Franklin, oral commun.) also reports that the areas of irrigated crops has changed little in 20 years. This suggests that the irrigated area reported in 1974 was overestimated and, thus, the area of phreatophytes from Glancy and Katzer (1976, p. 63) was underestimated. Also, water-level declines in the Stagecoach subbasin have caused discharge by about 3,500 acres of phreatophytes to decrease from $700 \mathrm{acre}-\mathrm{ft} / \mathrm{yr}$ to $180 \mathrm{acre}-\mathrm{ft} / \mathrm{yr}$ (Harrill and Preissler, 1994, p. H42). The areas determined for the present study from aerial photography were used to estimate discharge. However, more detailed mapping would allow refinement of the estimates.

Previous estimates of ground-water discharge rates by phreatophytes are $0.2 \mathrm{ft} / \mathrm{yr}$ in Stagecoach Valley (Harrill and Preissler, 1994, p. H18) and $0.3 \mathrm{ft} / \mathrm{yr}$ in Eagle Valley (Worts and Malmberg, 1966, p. 27). These values include both evaporation from bare soil and transpiration by phreatophytes. Recent work by Nichols (1994, p. 3271) suggests that transpiration by phreatophytes as a function of depth to water and leafarea index for a 100-day growing season could range from $0.07 \mathrm{ft} / \mathrm{yr}$, for a depth to water of $50 \mathrm{ft}$, to $0.8 \mathrm{ft} / \mathrm{yr}$, for a depth to water of $5 \mathrm{ft}$. For this study, the range in rates used for evapotranspiration is assumed to include both bare soil evaporation and plant transpiration. Near the Carson River, where depth to water probably ranges from 5 to $15 \mathrm{ft}$, rates of 0.2 and $0.6 \mathrm{ft} / \mathrm{yr}$ are used to estimate the potential range in discharge (table 9). For phreatophyte stands away from the Carson River, rates reported by Nichols $(1994$, p. 3271) were used for the depth to water measured in nearby wells. 
Consumptive use by alfalfa, the primary crop in most of the area, has been estimated to range from $3.0 \mathrm{ft} / \mathrm{yr}$ to $4.8 \mathrm{ft} / \mathrm{yr}$, depending on the method used to calculate the rate-TR-21 Blaney-Criddle method or FAO Blaney-Criddle method (U.S. Soil Conservation Service, 1992, p. NV683-41). Near the Carson River where crops are irrigated with surface water and ground water is at shallow depth, crops probably derive water for consumptive use from both surface water and ground water. To account for the loss of water from both sources, the total estimated range in consumptive use is used to estimate this source of discharge (table 9). In the Carson Plains subbasin where ground water is pumped for irrigation in average-to-dry years, the net volume of estimated agricultural pumping is subtracted from estimates of crop consumptive use to avoid a double accounting of discharge by crop consumptive use (table 13). In the Stagecoach subbasin, agricultural use of ground water is mainly for production of sod. Secondary recharge from agricultural pumping has been calculated to be 150 acre-ft/yr by Harrill and Preissler (1994, p. H41). Consumptive use in the Stagecoach subbasin is assumed to equal net agricultural pumping (table 13).

Table 9. Evapotranspiration from phreatophyte areas and irrigated land in subbasins of Dayton Valley Hydrographic Area, Nevada

[Abbreviations: acre-ft, acre-feet; ET, evapotranspiration; ft, feet; ft/yr, feet per year. Symbol: --, none]

\begin{tabular}{|c|c|c|c|c|c|c|}
\hline \multirow[b]{2}{*}{ Subbasin } & \multicolumn{3}{|c|}{ Phreatophytes } & \multicolumn{3}{|c|}{ Irrigated land } \\
\hline & $\begin{array}{c}\text { Area }^{1} \\
\text { (acres) }\end{array}$ & $\begin{array}{c}\text { ET rate } \\
\text { (ft/yr) }\end{array}$ & $\begin{array}{l}\text { Annual ET } \\
\text { discharge } \\
\text { (acre-ft) }\end{array}$ & $\begin{array}{c}\text { Area }^{1} \\
\text { (acres) }\end{array}$ & $\begin{array}{l}\text { ET rate } \\
\text { (ft/yr) }\end{array}$ & $\begin{array}{l}\text { Annual ET } \\
\text { Consumptive use } \\
\text { (acre-ft) }\end{array}$ \\
\hline Riverview. ..... & 500 & $0.2-0.6$ & $100-300$ & 900 & $3.0-4.8$ & $2,700-4,300$ \\
\hline Mound House & 300 & $0.2-0.6$ & $60-200$ & -- & -- & -- \\
\hline Carson Plains.... & $\begin{array}{r}30 \\
160 \\
2,200\end{array}$ & $\begin{array}{l}{ }^{4} 0.26 \\
{ }^{5} 0.07 \\
0.2-0.6\end{array}$ & $\begin{array}{l}7 \\
10 \\
440-1,300\end{array}$ & 1,800 & $3.0-4.8$ & $5,400-8,600$ \\
\hline Stagecoach..... & 3,500 & $6_{3.5}$ & ${ }^{7} 180$ & 300 & ${ }^{8} 2.8$ & ${ }^{9} 840$ \\
\hline Bull Canyon ..... & 1,700 & $0.2-0.6$ & $340-1,000$ & 400 & $3.0-4.8$ & $1,200-1,900$ \\
\hline Total (rounded) ... & 8,400 & $0.2-0.6$ & $1,100-3,000$ & 3,400 & $3.0-4.8$ & $10,000-16,000$ \\
\hline \multicolumn{7}{|c|}{$\begin{array}{l}{ }^{1} \text { Combined area of phreatophytes and irrigated land determined by Glancy and Katzer (1976, pl. 1); area of irrigated land } \\
\text { mined from aerial photography taken in } 1994 .\end{array}$} \\
\hline \multicolumn{7}{|c|}{$\begin{array}{l}{ }^{2} \text { Rate of } 0.2 \mathrm{ft} / \mathrm{yr} \text { from Harrill and Preissler (1994, } \mathrm{p} \text {. } \\
\text { anopy density of } 0.25 \text {, and } 100 \text {-day growing season. }\end{array}$} \\
\hline \multicolumn{7}{|c|}{$\begin{array}{l}{ }^{3} \text { Rate of } 3 \mathrm{ft} / \mathrm{yr} \text { is average for pasture and alfalfa using TR-21 Blaney-Criddle method; rate of } 4.8 \mathrm{ft} / \mathrm{yr} \text { is average for pasture } \\
\text { alfalfa using FAO Blaney-Criddle method. Rates estimated for Fernley, Nevada, area by U.S. Soil Conservation Service (1992, } \\
\text { V683-41), base period 1941-1970. }\end{array}$} \\
\hline \multicolumn{7}{|c|}{$\begin{array}{l}{ }^{4} \text { Rate of } 0.26 \mathrm{ft} / \mathrm{yr} \text { from Nichols }(1994, \text { p. } 3271) \text {, assuming depth to water of } 30 \mathrm{ft} \text {, canopy density of } 0.25 \text {, and } 100 \text {-day growing } \\
\text { n. }\end{array}$} \\
\hline \multicolumn{7}{|c|}{${ }^{5}$ Rate of $0.07 \mathrm{ft} / \mathrm{yr}$ from Nichols $(1994$, p. 3271 ), assuming depth to water of $50 \mathrm{ft}$, canopy density of 0.25 , and 100 -day growing } \\
\hline \multicolumn{7}{|c|}{$\begin{array}{l}{ }^{6} \text { Maximum rate of } 3.5 \mathrm{ft} / \mathrm{yr} \text { applied by ground-water flow model with extinction depth (depth at which significant } \\
\text { otranspiration ceases) of } 12-35 \mathrm{ft} \text { below land surface (Harrill and Preissler, 1994, p. H27). }\end{array}$} \\
\hline \multicolumn{7}{|c|}{$\begin{array}{l}{ }^{7} \text { Total volume as of } 1982 \text { calculated by ground-water flow model (Harrill and Preissler, 1994, p. H42); volume could be less } \\
94 \text {. }\end{array}$} \\
\hline \multicolumn{7}{|c|}{${ }^{8}$ Rate calculated from net agricultural pumping divided by irrigated acres } \\
\hline
\end{tabular}




\section{Subsurface Inflow and Outflow}

Subsurface flow can be estimated by using Darcy's Law, which states that the volume of flow is equal to the product of the hydraulic gradient, the saturated area through which flow takes place, and the hydraulic conductivity of saturated aquifer materials. The hydraulic gradient and estimates of aquifer properties are used herein to calculate estimates of subsurface flow using the following equation for Darcy's Law as modified from Heath (1989, p. 12):

$$
Q=0.0084 K A(d h / d l),
$$

where $Q$ is the quantity of ground water flow per unit time, in acre-feet per year;

$K$ is hydraulic conductivity, in feet per day;

$A$ is the cross-sectional area through which flow moves perpendicular to the direction of flow, in square feet;

$d h / d l$ is the hydraulic gradient, in feet per foot; and 0.0084 is the factor to convert cubic feet per day into acre-feet per year.

Subsurface flow from the Eagle Valley Hydrographic Area to the Dayton Valley Hydrographic Area (Riverview subbasin) north of Prison Hill was estimated to be about 1,600 acre-ft/yr by Worts and Malmberg (1966, p. 29). More recently, Arteaga and Durbin $(1979$, p. 32) estimated flow to be 1,500 acre$\mathrm{ft} / \mathrm{yr}$ and, using a ground-water flow model, Arteaga (1986, p. 31 and 43) obtained 700 acre-ft/yr for outflow under both natural conditions and conditions in 1978 .

Since 1978, municipal wells that supply water for Carson City have been installed in the Riverview subbasin (pl. 1). This pumping, and expansion and continued irrigation of the Eagle Valley golf course north of the subbasin boundary, could have increased the gradient and resulting subsurface flow across the boundary. Worts and Malmberg (1966, p. 29) used gradients of $0.005 \mathrm{ft} / \mathrm{ft}$ beneath Eagle Valley creek and $0.01 \mathrm{ft} / \mathrm{ft}$ near the northern part of the boundary, both of which are less than what was measured at those locations during 1995 for this study -0.01 and $0.06 \mathrm{ft} / \mathrm{ft}$, respectively. In addition, the previous studies considered consolidated rocks along the boundary to be impermeable. Because wells along the boundary pump water from consolidated rocks (wells E-10, E-11, E-12 and R-1; pl. 2), ground-water flow probably takes place through the rocks.

Subsurface inflow from Eagle Valley to the Riverview subbasin can be estimated by applying equation 1 to flow through cross-section $A$ - $A^{\prime}$ that is approximately parallel to the hydrographic-area boundary and water-level contours (inset, pl. 2). Thus, the curved section is approximately perpendicular to the direction of ground-water flow along its entire length.

The distribution of hydrogeologic units beneath the cross section was estimated using the mapped geology and lithologic descriptions from driller's logs for six wells near the section (inset, p1. 2). Metamorphic rocks are exposed at the northeastern end of the section, and are overlain by Quaternary basalt penetrated at wells E-10 and E-11 and exposed west of a fault. Basin-fill sediments are about $300 \mathrm{ft}$ thick at well E-11. The basalt was not encountered at well E-12 where about $300 \mathrm{ft}$ of multicolored volcanic rock, probably rhyolitic, overlies granitic rock. At well R-1, basinfill sediments about $700 \mathrm{ft}$ thick overlie granitic rock. Rocks about $150 \mathrm{ft}$ beneath the granitic rocks are described as "gray, hard, and porphyritic" and could be metamorphic. Consolidated rocks beneath about $400 \mathrm{ft}$ of basin-fill sediments at well R-6 and described only as "large, hard, and bedrock" are probably also metamorphic rocks. Faulted metamorphic rocks underlie basin-fill sediments estimated to be about $200 \mathrm{ft}$ thick beneath the southwestern end of the section. The distribution of hydrogeologic units is approximate because the lateral extent of units between wells is not known, and lithologic descriptions at wells R-6 and R-7 were projected westward across a fault.

The area of each unit was determined by drawing the distribution to scale on graph paper and totaling the number of grid cells within saturated basin-fill sediments and consolidated rock. Recent work on the western side of Eagle Valley has shown the buried surface of consolidated rocks to be weathered and fractured to depths of 50-70 ft (Maurer and others, 1996). Because wells along the boundary have penetrated from 75 to as much $190 \mathrm{ft}$ of fractured rock (wells R-6 and E-12, respectively), the upper $100 \mathrm{ft}$ of consolidated rock is assumed to be sufficiently weathered and fractured to transmit water.

The transmissivity of hydrogeologic units was estimated from the specific capacity reported on drillers' logs and reported values for wells near the section (table 10), using an equation modified from Thomasson and others (1960, p. 222):

$$
T=267(S C) \text {, }
$$

where $T$ is transmissivity, in feet squared per day, and

$S C$ is specific capacity, in gallons per minute per foot of drawdown. 
Hydraulic conductivity can then be calculated as the transmissivity divided by the perforated interval of the well. The computation assumes that the well is 100 percent efficient, which generally is not known. However, reasonable values of hydraulic conductivity were obtained using the equation.

Because the hydraulic gradient changes along the section, flow was calculated by dividing the section into two parts. Northeast of well R-1, a gradient of $0.06 \mathrm{ft} / \mathrm{ft}$ was used and southwest of $\mathrm{R}-1$, a gradient of $0.01 \mathrm{ft} / \mathrm{ft}$ was used (table 11). In the basin-fill sediments, hydraulic conductivity estimated from the drillers' logs is probably representative of only the more conductive parts of the basin-fill sediments, because wells are often screened only in the most productive zones. At wells E-11 and R-6, the coarsegrained parts of the basin-fill sediments were screened, whereas clayey, or fine-grained, parts were not. To account for this, the ratio of the screened interval to the total saturated thickness of basin-fill sediments was used to estimate cross-sectional areas of coarse- and fine-grained sediments from the total area of saturated basin-fill sediments. Northeast of well R-1, the ratio from well E-11 was used (0.33), and southwest of R-1, the ratio from well R-6 was used (0.28). The distribution of hydraulic conductivity within basin-fill sediments at these wells was assumed to be representative of basin-fill sediments in the northern and southern parts of the cross section.

The hydraulic conductivity assigned to hydrogeologic units in table 11 was based on values for hydrogeologic units shown in table 10 . For finegrained basin-fill sediments and granitic and metamorphic rocks, conductivity values obtained for similar hydrogeologic units on the western side of Eagle Valley were used. There, the hydraulic conductivity of metamorphic rocks was found to range from about 2 to $60 \mathrm{ft} / \mathrm{d}$, depending on the degree of weathering, fracturing, and the presence of clay in fractures. Weathered granitic rock and fine-grained basin-fill sediments had

Table 10. Estimates of transmissivity and hydraulic conductivity for selected wells near hydrogeologic section A-A', along the western boundary of the Riverview subbasin, Dayton Valley Hydrographic Area, Nevada, using data reported on drillers' logs and other reported values

[Abbreviations: $\mathrm{ft}$, feet; $\mathrm{ft} / \mathrm{d}$, feet per day; $\mathrm{ft}^{2} / \mathrm{d}$, feet squared per day; gal/min, gallon per minute; [gal/min]/ft, gallon per minute, per foot. Symbols: --, data not used; $\%$, percent]

\begin{tabular}{|c|c|c|c|c|c|c|c|}
\hline $\begin{array}{l}\text { Site } \\
\text { (pl. 2) }\end{array}$ & $\begin{array}{l}\text { Pumping rate } \\
\text { (gal/min) }\end{array}$ & $\begin{array}{c}\text { Drawdown } \\
\text { (ft) }\end{array}$ & $\begin{array}{c}\text { Specific } \\
\text { capacity }{ }^{1} \\
([\text { gal/min]/ft) }\end{array}$ & $\begin{array}{c}\text { Transmissivity }{ }^{2} \\
\text { (ft }{ }^{2} / \text { day) }\end{array}$ & $\begin{array}{c}\text { Perforated } \\
\text { interval }^{3} \\
(\mathrm{ft})\end{array}$ & $\begin{array}{l}\text { Hydraulic } \\
\text { conductivity } \\
\text { (ft/day) }\end{array}$ & $\begin{array}{c}\text { Hydrogeologic } \\
\text { Unit } 5\end{array}$ \\
\hline E-10 & 50 & 90 & 0.56 & 150 & 40 & 3.8 & $\mathrm{Qb}$ \\
\hline E-11 & 120 & 84 & 1.4 & 370 & 250 & 1.5 & $\begin{array}{l}40 \% \mathrm{Qal} \\
60 \% \mathrm{Qb}\end{array}$ \\
\hline E-7 & -- & -- & -- & -. & -- & ${ }^{6} 2.7$ & Qal \\
\hline R-1 & -- & -- & -- & ${ }^{7} 24$ & ${ }^{8} 233$ & 0.1 & $\begin{array}{l}25 \% \mathrm{Qal} \\
75 \% \mathrm{Kg}\end{array}$ \\
\hline R-6 & 415 & 117 & 3.5 & 950 & 110 & 8.6 & Qal \\
\hline R-7 & 30 & 20 & 1.50 & 400 & 20 & 20 & Qal \\
\hline
\end{tabular}

${ }^{1}$ Specific capacity equals pumping rate divided by drawdown.

${ }^{2}$ Rounded; calculated using equation 3 in text, equal to specific capacity multiplied by 267 (Thomasson and others, 1960, p. 222).

${ }^{3}$ Total of screened intervals reported on drillers' logs.

${ }^{4}$ Hydraulic conductivity equals transmissivity divided by perforated interval.

${ }^{5}$ Percent of hydrogeologic unit adjacent to perforated interval; no value indicates 100 percent. Qal, unconsolidated basin-fill sediments; $\mathrm{Qb}$, basaltic volcanic rocks; $\mathrm{Kg}$, granitic rocks.

${ }^{6}$ Value reported by J.H. Kleinfelder \& Associates (1985, p. 22).

${ }^{7}$ Value reported by Lumos \& Associates, Inc., and Watersource, Inc. (1986, p. 7-16).

${ }^{8}$ Value is perforated interval minus hard rock adjacent to perforated interval. 
conductivities averaging about $1 \mathrm{ft} / \mathrm{d}$ and $0.3 \mathrm{ft} / \mathrm{d}$, respectively (Maurer and others, 1996, p. 28). The value of $1.0 \mathrm{ft} / \mathrm{d}$ used in table 11 for metamorphic rocks south of well R-1 is, thus, fairly conservative, lacking actual measurements. Values for basin-fill sediments are similar to those used in the ground-water flow model developed by Arteaga (1986, pl. 5). The estimate for subsurface flow from Eagle Valley to the Dayton Valley Hydrographic Area is 2,200 acre-ft/yr (table 11).

Water-level data for the area east of Hot Springs Mountain are not available to confirm a hydraulic gradient from Carson Valley toward the Riverview subbasin. Because the water level at well R-18 is below the altitude of the river's stream stage (table 5), subsurface inflow across the divide presumably is minimal.
Subsurface flow beneath the Carson River at the boundaries of the Dayton Valley Hydrographic Area was estimated previously by Glancy and Katzer (1976, p. 51). Those values and estimates for subsurface flow beneath the Carson River at subbasin boundaries made for this study are summarized in table 12 . Because the hydraulic gradient was assumed to equal the slope of the stream channel, and the cross-sectional area and hydraulic conductivity were estimated, the subsurface flow estimates are approximate and could be in error by an order of magnitude.

Subsurface flow to and from the Stagecoach subbasin for 1982 conditions was previously estimated by Harrill and Preissler (1994, p. H42). Continued pumping from 1982 to 1994 in the Stagecoach subbasin could have changed those volumes.

Table 11. Estimated subsurface flow from Eagle Valley to Dayton Valley Hydrographic Area, Nevada

[Abbreviations: acre-ft/yr, acre-feet per year; $\mathrm{ft} / \mathrm{d}$, foot per day; $\mathrm{ft}^{2}$, square feet; $\mathrm{ft} / \mathrm{ft}$, feet per foot]

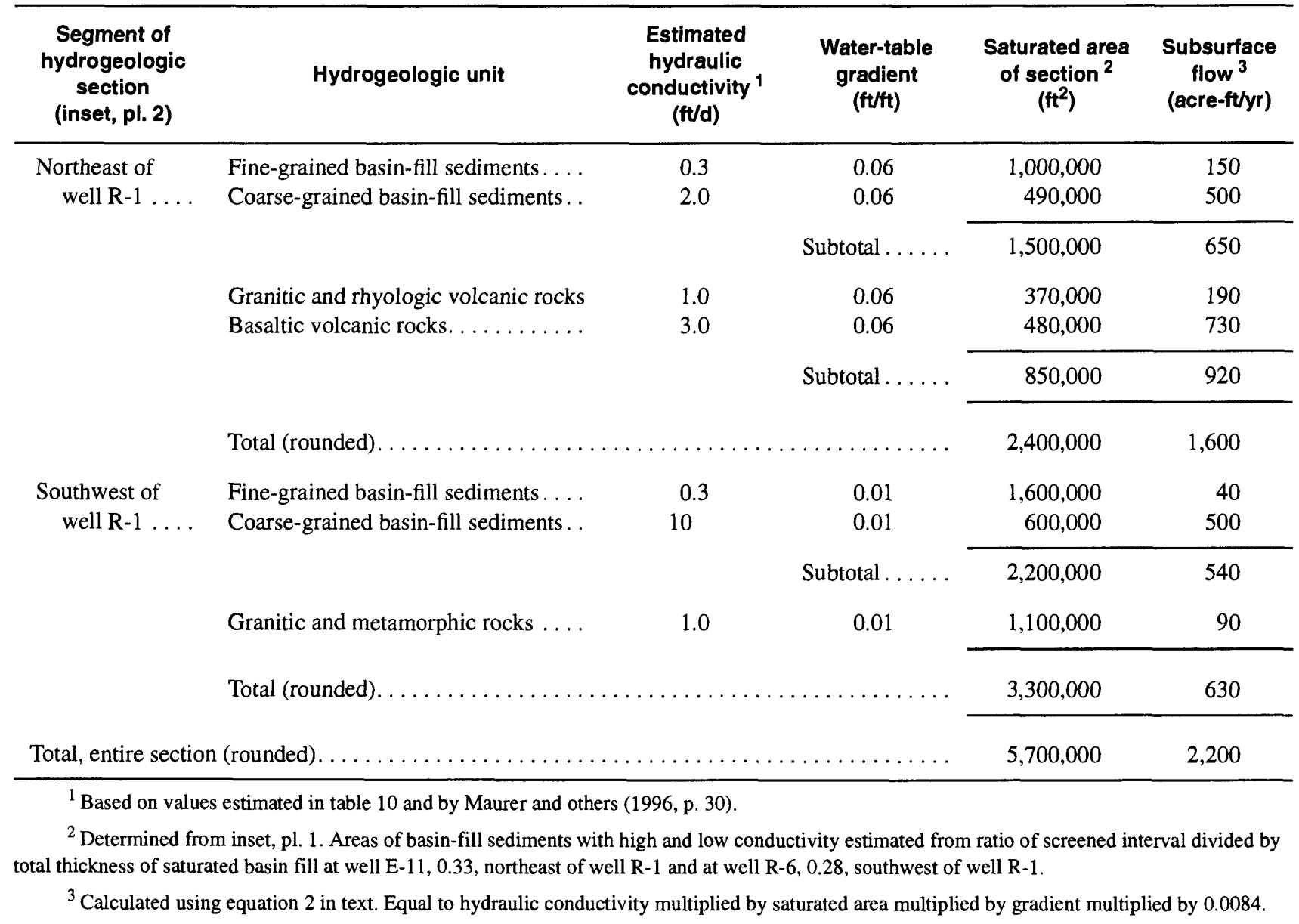


Table 12. Estimated subsurface flow to and from subbasins of the Dayton Valley Hydrographic Area, Nevada

[Abbreviations: acre-ft/yr, acre-foot per year; $\mathrm{ft}$, foot; $\mathrm{ft}^{2}$, square feet; $\mathrm{ft} / \mathrm{d}$, foot per day; $\mathrm{ft} / \mathrm{ft}$, feet per foot. Symbol: --, not calculated in this table]

\begin{tabular}{|c|c|c|c|c|c|c|c|}
\hline Flow to & From & $\begin{array}{c}\text { Estimated } \\
\text { thickness } \\
\text { (ft) }\end{array}$ & $\begin{array}{c}\text { Estimated } \\
\text { saturated } \\
\text { area } \\
\left(\mathrm{ft}^{2}\right)\end{array}$ & $\begin{array}{c}\text { Estimated } \\
\text { hydraulic } \\
\text { conductivity } \\
(\mathrm{ft} / \mathrm{d})\end{array}$ & $\begin{array}{c}\text { Estimated } \\
\text { gradient }{ }^{1} \\
(\mathrm{ft} / \mathrm{ft})\end{array}$ & $\begin{array}{c}\text { Estimated } \\
\text { width } \\
\text { of flow } \\
\text { section } \\
\text { (ft) }\end{array}$ & $\begin{array}{c}\text { Estimated } \\
\text { subsurface } \\
\text { flow }^{2} \\
\text { (acre-ft/yr, } \\
\text { rounded) }\end{array}$ \\
\hline Riverview subbasin & Carson Valley & 100 & 26,000 & 35 & 0.0019 & 260 & ${ }^{3} 15$ \\
\hline Riverview subbasin & Eagle Valley . & -- & -- & -- & -- & -- & ${ }^{4} 2,200$ \\
\hline Carson Plains subbasin. & Mound House subbasin & 200 & 120,000 & 70 & .007 & 600 & 500 \\
\hline Stagecoach subbasin... & Carson Plains subbasin. & 100 & $1,000,000$ & 1 & .0019 & 10,000 & 20 \\
\hline Stagecoach subbasin. & Bull Canyon subbasin. . & -- & -- & -- & -- & - & $5^{5} 400$ \\
\hline Bull Canyon subbasin. . & Carson Plains subbasin. & 200 & 300,000 & 35 & .0045 & 1,500 & 400 \\
\hline Bull Canyon subbasin. . & Stagecoach subbasin. .. & -- & -- & -- & -- & -- & ${ }^{6} 110$ \\
\hline
\end{tabular}

\footnotetext{
${ }^{1}$ Estimated from water levels near subbasin boundaries, where available. Assumed to be equal to slope of stream channel estimated from 1:24,000 topographic maps where water levels not available.

${ }^{2}$ Estimated using equation 2 in text. Equal to hydraulic conductivity multiplied by saturated area multiplied by gradient multiplied by 0.0084 .

${ }^{3}$ Modified from Glancy and Katzer (1976, p. 51).

${ }^{4}$ Table 11.

${ }^{5}$ Estimated by Harrill and Preissler (1994, p. H42) for conditions in 1982; includes 300 acre-ft/yr near the western side of subbasin and 98 acre-ft/yr near southern side.

${ }^{6}$ Estimated by Harrill and Preissler (1994, p. H42) for conditions in 1982.
}

\section{ESTIMATED WATER BUDGETS FOR SUBBASINS AND FOR DAYTON VALLEY HYDROGRAPHIC AREA}

Components of inflow and outflow estimated for each subbasin are presented in tables 6 through 12 and summarized in table 13 . Recharge from precipitation and streamflow generated within each subbasin was estimated by applying the Maxey-Eakin method to the three precipitation distributions. For this reason, three estimates of total ground-water inflow were obtained. Similarly, a range in crop consumptive use rates was used to obtain a range of values for total outflow in subbasins with irrigated crops.

\section{Riverview Subbasin}

Total estimates of inflow to ground water in the subbasin are 5,600, 5,800, and 6,900 acre-ft/yr (table 13). Total estimated outflow is slightly larger than inflow, 6,600-8,400 acre-ft/yr. Because water levels in the subbasin do not appear to be declining, the apparent imbalance is probably caused by inaccuracies in estimates of inflow and outflow. Estimates of crop con- sumptive use and streamflow losses from the Carson River are the most uncertain of the largest water-budget components. Refined estimates of these components could reduce the apparent imbalance. The estimate of subsurface flow from the Eagle Valley Hydrographic Area is larger than previous estimates because of the increased gradient across the hydrographic area boundary and because an estimate for flow through consolidated rocks was included. Subsurface outflow beneath the channel of the Carson River to the Mound House subbasin could be a minimum value because the channel is bounded by metamorphic rocks that could have at least a moderate hydraulic conductivity.

\section{Mound House Subbasin}

Total estimates of inflow to ground water in the subbasin are 3,300, 3,700, and 5,600 acre-ft/yr, whereas estimates of outflow are much less, 600-800 acre-ft/yr (table 13). Because historical water-level measurements are lacking, possible changes in groundwater storage cannot be confirmed. However, because outflow is less than inflow, recharge from precipitation or from stream losses along the Carson River could 


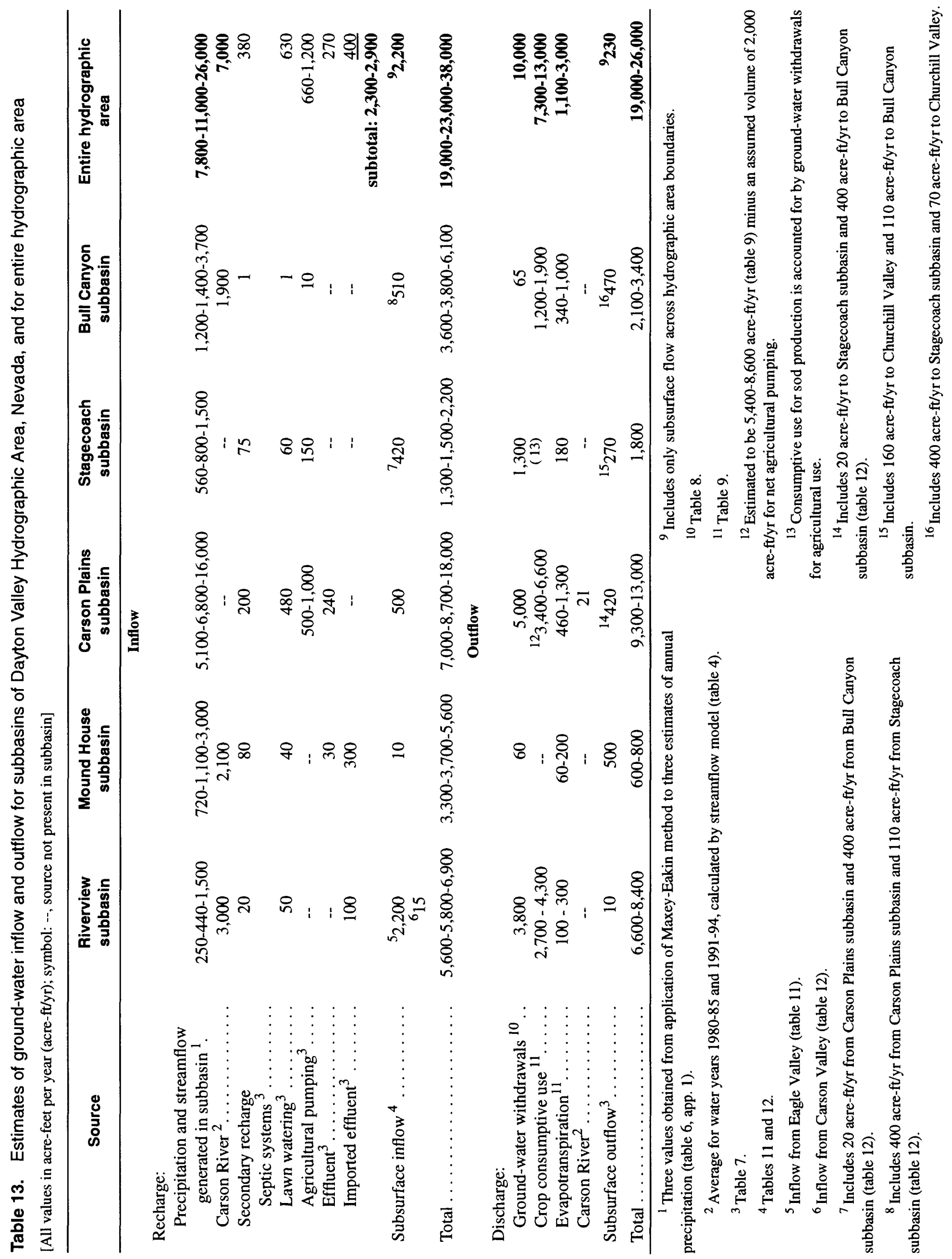


be overestimated. Also, outflow beneath the channel of the Carson River near the Carson Plains subbasin boundary could be greater than estimated. Here, channel deposits are much coarser than at other subbasin boundaries, consisting of gravel, cobbles, and boulders. Reported values of hydraulic conductivity for such coarse deposits range as high as $10,000 \mathrm{ft} / \mathrm{d}$ (Freeze and Cherry, 1979, p. 29). Thus, the estimated hydraulic conductivity of $70 \mathrm{ft} / \mathrm{d}$ (table 12) could be a minimum value, and subsurface flow could be greater by an order of magnitude or more. Outflow also could take place through volcanic rocks toward the Carson Plains subbasin. Additional wells both north and south of the river would allow evaluation of the potential for such flow.

\section{Carson Plains Subbasin}

Total estimates of inflow to the subbasin are $7,000,8,700$, and $18,000 \mathrm{acre}-\mathrm{ft} / \mathrm{yr}$, whereas estimates of outflow are 9,300-13,000 acre-ft/yr (table 13). An assumed volume of 2,000 acre-ft/yr for net ground water pumped to meet crop consumptive use was subtracted from estimates of total crop consumptive use to avoid a double accounting of this source of outflow. Because water levels could be declining in a small part of the subbasin, ground-water discharge would be expected to be somewhat greater than ground-water recharge. If water levels have declined about $5 \mathrm{ft}$ beneath about $2 \mathrm{mi}^{2}$ and specific yield of the aquifer is about 0.2 , about 1,300 acre-ft were removed from ground-water storage from 1981 to 1995 . Because frequent water-level measurements are lacking, the annual amount of change in storage cannot be determined. Water-use records show that an increase in the number of customers supplied by water, and in pumping for the Dayton Valley Golf Course, began in the early 1990's. If water levels have declined over a 5-year period, from 200 to $300 \mathrm{acre}-\mathrm{ft} / \mathrm{yr}$ has been removed from storage. Although not conclusive, this suggests that the mid-range estimate of 8,700 acre-ft/yr provides the best balance. The apparent imbalance could also be reduced if subsurface inflow from the Mound House subbasin is greater than estimated. Recharge from precipitation and discharge to seepage along the Carson River, agricultural pumping, evapotranspiration, and crop consumptive use are also uncertain water-budget components.

\section{Stagecoach Subbasin}

Total estimates of inflow to the subbasin are $1,300,1,500$, and 2,200 acre-ft/yr, whereas estimates of outflow total 1,800 acre-ft/yr (table 13). Because ground-water storage is decreasing in the subbasin, outflow would be expected to be somewhat greater than inflow. Harrill and Preissler (1994, p. H41) calculated that storage decreased by about 450 acre-ft/yr from 1971 to 1982, and water levels declined from 1982 to 1994 at about the same rate (fig 3B). If 450 acre-ft/yr of the outflow came from ground-water storage during 1982-94, the low and mid-range estimates of inflow appear to be the most reasonable.

\section{Bull Canyon Subbasin}

Total estimates of inflow to the subbasin are $3,600,3,800$, and 6,100 acre-ft/yr, whereas estimates of outflow are 2,100-3,400 acre-ft/yr (table 13). Because the amount of ground-water pumpage is small, ground-water storage probably has not changed. The apparent imbalance could be caused by overestimation of recharge using the 1996 Nevada precipitation map or overestimation of infiltration of streamflow along the Carson River.

\section{Entire Dayton Valley Hydrographic Area}

Recharge to the Dayton Valley Hydrographic Area, estimated from the precipitation distribution presented by Glancy and Katzer (1976, p. 48), from a relation between distance, altitude, and precipitation, and from the 1996 Nevada precipitation map, is 7,800, 11,000 , and 26,000 acre-ft/yr, respectively (table 6). More recharge is estimated by using the distancealtitude relation and the 1996 Nevada precipitation map than by Glancy and Katzer (1976, p. 48). This is because the relations predict more total precipitation, and more precipitation for amounts greater than $15 \mathrm{in} / \mathrm{yr}$ where a larger percentage is assumed to become recharge. Recharge to the individual subbasins estimated from the distance-altitude relation is from 17 to 76 percent greater than that estimated from the precipitation distribution used by Glancy and Katzer (1976) (app. 1). Recharge to subbasins calculated using the precipitation distribution from the 1996 Nevada precipitation map ranges from about 170 to 500 percent greater than that estimated from the precipitation distribution used by Glancy and Katzer (1976). Thus, the 
volume of recharge calculated by application of the Maxey-Eakin percentages is greatly dependent on the distribution of precipitation. The accuracy of the method is unknown, but can be assessed by comparison with estimates of discharge. Additional study would allow evaluation of the applicability of the MaxeyEakin method to different estimates of mean annual precipitation.

Estimates of the range of inflow to and outflow from ground water in the entire Dayton Valley Hydrographic Area were made by combining the estimates of recharge and discharge for each subbasin with estimates of subsurface flow only at the hydrographic-area boundaries (table 13). Total estimates of inflow are $19,000,23,000$, and 38,000 acre-ft/yr, including 7,800, 11,000 , and 26,000 acre-ft/yr from infiltration of precipitation and streamflow generated within the area (table 6), 7,000 acre-ft/yr from stream losses of the Carson River (table 4), 2,300-2,900 acre-ft/yr of secondary recharge of pumped water (table 7), and 2,200 acre-ft/yr of subsurface inflow from Eagle and Carson Valleys (table 12). Estimates of outflow are 19,000$26,000 \mathrm{acre}-\mathrm{ft} / \mathrm{yr}$, including 10,000 acre-ft/yr of ground-water pumping (table 8), 7,300-13,000 acre$\mathrm{ft} / \mathrm{yr}$ discharged by crop consumptive use not supplied by ground-water pumping (tables 9 and 13), 1,1003,000 acre-ft/yr discharged by phreatophytes (table 9 ), and 230 acre-ft/yr of subsurface outflow to Churchill Valley (table 12).

The net inflow and outflow of 17,000 acre-ft/yr estimated by Glancy and Katzer (1976, p. 66) for Dayton Valley is similar to the low-range estimate and about half of the high-range estimate made in this study. Estimates made by Glancy and Katzer are different from those made in this study for several reasons. During the period of study by Glancy and Katzer, ground-water pumping in the area was minimal and secondary recharge from pumping was not considered. Discharge by ground-water pumping, crop consumptive use, and evapotranspiration was estimated to total 16,000 acre-ft/yr (Glancy and Katzer, 1976, p. 66). The estimate was obtained "by difference" (Glancy and Katzer, 1976, p. 62), meaning that 16,000 acre-ft/yr was the volume required to balance inflow and outflow. Using current pumping estimates and applying a range of rates for crop consumptive use and evapotranspiration, discharge can be shown to range from 19,000 to 26,000 acre-ft/yr (table 13). Finally, recharge from precipitation and streamflow generated within the area could be greater if precipitation is greater than that estimated from the altitude-precipitation relation used by Glancy and Katzer (1976, p. 48) and if the method of estimating recharge is applicable (table 6).

Comparison of the ranges for inflow and outflow can provide insight as to how reasonable the ranges might be. The low-range and mid-range estimates of inflow are similar to the low-range estimate of outflow. However, the high-range estimate of inflow is more than 10,000 acre-ft/yr greater than the maximum estimate of outflow. Thus, the high-range estimate of inflow appears to be the most questionable.

The estimate for recharge from precipitation and streamflow generated within the area is most likely to be inaccurate because of the many uncertainties in the method used to estimate recharge from these sources. Application of the Maxey-Eakin method to the three precipitation distributions gives a range of estimates in each subbasin for this source of recharge. The five ranges (table 13) differ from a low value of 1,000 to a high value of over $10,000 \mathrm{acre}-\mathrm{ft} / \mathrm{yr}$. Estimates of recharge from streamflow losses along the Carson River also have a large degree of uncertainty and could be in error by thousands of acre-feet per year over the entire hydrographic area.

The largest components of outflow are crop consumptive use, ground-water withdrawals, and evapotranspiration. Because the consumptive use rates used in the estimate are based on empirical formulas, actual use rates could be different. However, the range in rates used ( 3.0 to $4.8 \mathrm{ft} / \mathrm{yr}$ ) is considered to represent a reasonable range for crop consumptive use and results in a maximum range of about 3,000 acre-ft/yr for the Carson Plains subbasin (table 13). Because municipal use is metered and domestic use is small, the most uncertain component of ground-water withdrawals is agricultural pumping. The volume of agricultural pumping is based on estimates made in 1983 from water-righted acres and assumed rates and durations of pumping. This could cause the estimate for agricultural pumping to be in error by possibly a few thousands of acre-feet per year. The range of rates used to estimate evapotranspiration is consistent with those actually measured at various locations in Nevada (Nichols, 1994, p. 3271) and used in previous studies in the area (Harrill and Preissler, 1994, p. H18). The rates are believed to be reasonable, and they result in a range of less than 1,000 acre-ft/yr for the individual subbasins (table 13). The areas of irrigated crops and phreatophytes were determined from aerial photography and not from detailed field mapping. This could be a source 
of inaccuracy for estimates of both crop consumptive use and evapotranspiration if areas that are irrigated were mapped as areas of phreatophytes. If as many as 500 acres were mapped incorrectly, the error in the estimated discharge would be about 2,000 acre-ft/yr.

The total inaccuracy in estimates of outflow for the entire hydrographic area is probably less than 10,000 acre-ft/yr, whereas the inaccuracy in estimates of inflow could be much greater than 10,000 acre- $\mathrm{ft} / \mathrm{yr}$. Thus, the high-range estimate of inflow calculated using the 1996 Nevada precipitation map could be too high. Additional study would allow evaluation of important water-budget components and refinement of water budgets for subbasins and for the entire hydrographic area.

\section{Possible Future Refinement of Estimated Water Budgets}

Estimates of recharge and discharge presented in this report include many uncertainties. In approximate order of the volume estimated for each water-budget component, uncertainties include (1) the distribution of precipitation within the study area; (2) the accuracy of applying the Maxey-Eakin method of estimating recharge to a precipitation distribution other than that used in the original method and to parts of a hydrographic area; (3) the volume of water interchanged between the surface- and ground-water systems; (4) the rates of crop consumptive use and evapotranspiration; (5) the volume of water pumped for agricultural use;

(6) the volume of pumped water that returns to the ground-water system after use; and (7) the volume of subsurface flow between Carson Valley and the Riverview subbasin, between the Mound House and Carson Plains subbasins, and between the Carson Plains and Stagecoach subbasins.

Uncertainties in these water-budget components could be refined by collection of additional hydrologic data on annual precipitation, subsurface flow from the mountain blocks to the basin-fill aquifers, hydraulic gradients between stream stage and the adjacent water table, streamflow gains and losses, agricultural pumping, and water levels in areas where wells are lacking. Also, the direction of ground-water flow is poorly understood south and east of the Carson River in the Riverview subbasin, north and south of the Carson River in the Mound House subbasin, and near the mouth of Eldorado Canyon in the Carson Plains subbasin. Installation of monitoring wells and continued measurements of water-level fluctuations would provide a better understanding of how recharge from precipitation and the Carson River moves through the ground-water system. Measurement of hydraulic gradients and aquifer properties near the margins of the valley floors would allow estimation of subsurface flow from the mountain blocks toward the valley floor and an independent check on the accuracy of the Maxey-Eakin method of estimating recharge.

From these data, a better conceptual model of the hydrologic system can be formed and used to develop a numerical ground-water flow model. The numerical model could, in turn, be used to refine estimates of the complex interchange of flow between the surface- and ground-water systems and estimates of crop consumptive use and discharge by phreatophytes as a function of depth to water.

\section{SUMMARY AND CONCLUSIONS}

Increasing development in the Dayton Valley Hydrographic Area, east of Carson City, Nev., has caused concerns over the available ground-water supply (fig. 1). The water budget for the area was last assessed in the early 1970's as part of a ground-water reconnaissance study of the entire Carson River Basin (Glancy and Katzer, 1976). Work began in 1994 to update the hydrologic data base for the three western subbasins, describe the hydrogeologic setting of the three western subbasins and the entire area, reassess key water-budget elements, update and refine the water budget developed in the early 1970's for the entire hydrographic area, develop water budgets for the individual subbasins, and determine additional work needed to refine water-budget elements.

The Dayton Valley Hydrographic Area was divided into five subbasins using topographic divides between subbasin watersheds. From west to east the subbasins are: Riverview, Mound House, Carson Plains, Stagecoach, and Bull Canyon.

Consolidated rocks that form mountain blocks and underlie basin-fill sediments beneath the valley floors were grouped into five hydrogeologic units consisting of granitic and metamorphic rocks, and rhyolitic, andesitic, and basaltic volcanic rocks. Basin-fill sediments were divided into two hydrogeologic units consisting of partly consolidated and 
unconsolidated sediments. Basin-fill sediments are the most developed aquifers in the area, but wells also produce water from all other units.

Three estimates of the distribution of mean annual precipitation in the hydrographic area and in each subbasin were obtained using (1) a previously published relation between annual precipitation and altitude, (2) a relation developed for this study between annual precipitation, altitude, and distance from the Sierra Nevada crest, and (3) a precipitation map for Nevada produced in 1996. Estimates of total annual precipitation are 180,000 acre-ft using the first distribution, 200,000 acre-ft using the second, and 250,000 acre-ft using the third. Both the second and third distributions estimate more precipitation at higher altitudes than the previously published relation.

Perennial streamflow in the area is limited to the Carson River and Eagle Valley creek, which enters the Riverview subbasin from the west with an average flow of 2,200 acre-ft/yr (period of record, water years 1985-94). Average flow of the Carson River for the period of record common to gaging stations on the river, water years $1980-85$ and 1991-94, is 332,000 acre-ft/yr at the upstream hydrographic-area boundary and 322,200 acre-ft/yr at the downstream boundary. During periods of low flow, the river can become dry at the downstream boundary. Diversions of Carson River flow in the Riverview subbasin average 6,800 acre-ft/yr, and in the Mound House, Carson Plains, and Bull Canyon subbasins average 22,000 acre-ft/yr. Ephemeral streams tributary to the Carson River flow to the river only during snowmelt runoff or intense storms.

The accuracy of gaging-station data and of instantaneous measurements made during periods of low flow results in only approximate volumes of streamflow gains and losses along the Carson River through the hydrographic area. Simulations of streamflow over a 10-year period, using a physically based model, suggest that the Carson River loses flow through the Riverview, Mound House, and Bull Canyon subbasins at an average rate of 3,000, 2,100 , and 1,900 acre-ft/yr, respectively. Through the Carson Plains subbasin, a net loss was simulated during normal-to-wet years and a net gain was simulated during dry years, for an average annual gain of 21 acre-ft/yr.

As a qualitative check on measured stream losses, the hydraulic gradient between stream stage of the Carson River and the adjacent water table was measured at 13 wells from June 1995 to January 1996. The gradient data show that the volume of water gained or lost from the Carson River varies with location along the river, from one bank to another, and with stream stage.

Water-level measurements at 106 wells, made mostly in December 1995, were used to develop contours of water-level altitude in the study area. The contours were used to estimate the direction of ground-water flow and to assess the potential for interbasin flow.

In the Riverview subbasin, water levels suggest a potential for subsurface flow into the Dayton Valley Hydrographic Area from the Carson Valley Hydrographic Area east of Hot Springs Mountain. No water levels are available near the boundary to confirm such flow, and water levels in the Riverview subbasin near the Carson River suggest that such flow probably is minimal. Near the northern part of the Riverview subbasin, subsurface flow of 2,200 acre-ft/yr was estimated from Eagle Valley to the Dayton Valley Hydrographic Area. East of the Carson River, water levels indicate flow parallel to the river or toward the east, possibly through fractured metamorphic rocks, to a downstream reach of the Carson River in the Mound House subbasin.

In the Mound House subbasin, available water levels north of the Carson River indicate little potential for interbasin flow to or from the subbasin. Ground water in basin-fill sediments flows from the northwest to the southeast toward the Carson River. However, streamflow measurements indicate a loss through the subbasin. This fact, and differences in water levels, suggest that ground water in basin-fill sediments could be perched, or poorly connected with a deeper water table in underlying volcanic rocks.

In the westernmost part of the Carson Plains subbasin, ground water flows eastward toward the valley floor. Beneath the valley floor, ground water flows to the northeast, parallel to the Carson River. South of the Carson River, the altitude of springs suggests a steep hydraulic gradient from the base of the Pine Nut Mountains toward the valley floor. Near the eastern boundary, water levels indicate the potential for subsurface flow into the Stagecoach subbasin. Water levels south of the Carson River and east of Dayton remained from 3 to $8 \mathrm{ft}$ lower during December 1995 than during 1981 , possibly because of increased nearby pumping. 
Estimated ground-water budgets for the hydrographic area and its subbasins include estimates of inflow from infiltration of precipitation and streamflow generated within the area; infiltration of streamflow along the Carson River; infiltration of ground water pumped for municipal, domestic, and agricultural purposes; and subsurface flow from the adjacent Eagle and Carson Valley Hydrographic Areas and between the subbasins. The ground-water budgets also include estimates of outflow from ground water to evapotranspiration and crop consumptive use; seepage to the Carson River; ground-water pumping for municipal, domestic, and agricultural purposes; and subsurface flow to the adjacent Churchill Valley Hydrographic Area, and between subbasins.

A range of values for recharge from infiltration of precipitation and streamflow generated within each subbasin was obtained by applying the Maxey-Eakin method to three different estimates of mean annual precipitation. The resulting estimates for the hydrographic area, 7,800, 11,000, and 26,000 acre-ft/yr, show that recharge estimated using the Maxey-Eakin method is greatly dependent on the distribution of precipitation. The accuracy of these estimates is unknown but can be assessed by comparison with estimates of discharge.

Estimates of inflow to ground water in the Riverview subbasin are 5,600,5,800, and 6,900 acre-ft/yr. Estimated outflow from ground water is slightly larger than inflow, 6,600-8,400 acre-ft/yr. Because water levels do not appear to be declining, uncertainties in estimates of crop consumptive use, streamflow losses along the Carson River, subsurface flow from Eagle Valley, and recharge from precipitation could contribute to the apparent imbalance.

Estimates of inflow to the Mound House subbasin are 3,300, 3,700, and 5,600 acre-ft/yr, whereas estimates of outflow are much less, ranging from 600 to 800 acre-ft/yr. Recharge from precipitation or from Carson River streamflow losses could be overestimated. Also, outflow beneath the channel of the Carson River could be an order of magnitude greater than estimated, or outflow could take place through volcanic rocks toward the Carson Plains subbasin.

Estimates of inflow to the Carson Plains subbasin are 7,000, 8,700, and 18,000 acre-ft/yr, whereas estimates of outflow are 9,300-13,000 acre-ft/yr. Water levels have possibly declined from 3 to $8 \mathrm{ft}$ from pumping, causing an estimated 200-300 acre-ft/yr decrease in ground-water storage. The apparent imbalance would also be reduced if subsurface inflow from the Mound House subbasin is greater than estimated. Recharge from precipitation and discharge to seepage along the Carson River, agricultural pumping, evapotranspiration, and crop consumptive use are also uncertain water-budget components.

Estimates of inflow to the Stagecoach subbasin are $1,300,1,500$, and 2,200 acre-ft/yr, whereas estimates of outflow total 1,800 acre-ft/yr. Because ground-water storage could be decreasing by 450 acre$\mathrm{ft} / \mathrm{yr}$, the low- and mid-range estimates appear to be the more reasonable.

Estimates of inflow to the Bull Canyon subbasin are 3,600,3,800, and 6,100 acre-ft/yr, whereas estimates of outflow are 2,100-3,400 acre-ft/yr. The apparent imbalance could be caused by overestimation of recharge of precipitation or of streamflow losses from the Carson River, which are the largest water-budget components for the subbasin.

Estimates of total inflow to ground water in the entire Dayton Valley Hydrographic Area are 19,000, 23,000 , and 38,000 acre-ft/yr, including 7,800,11,000, and 26,000 acre-ft/yr from infiltration of precipitation and streamflow generated within the area; 7,000 acre$\mathrm{ft} / \mathrm{yr}$ of stream losses from the Carson River; 2,3002,900 acre-ft/yr of secondary recharge of pumped water; and 2,200 acre-ft/yr of subsurface flow from Eagle Valley. Estimates of outflow are 19,000-26,000 acre-ft/yr and include 10,000 acre-ft/yr of groundwater pumping, 7,300-13,000 acre-ft/yr discharged by crop consumptive use not supplied by groundwater pumping, 1,100-3,000 acre-ft/yr discharged by phreatophytes, and 230 acre-ft/yr of subsurface outflow to Churchill Valley.

The low-range and mid-range estimates of inflow are similar to the range for estimates of outflow. In contrast, the high-range estimate of inflow is more than 10,000 acre-ft/yr greater than estimated outflow. Inaccuracies in estimates of inflow could be greater than 10,000 acre- $\mathrm{ft} / \mathrm{yr}$, whereas inaccuracies in estimates of outflow are probably less than 10,000 acre$\mathrm{ft} / \mathrm{yr}$. This implies that estimates of recharge using the 1996 Nevada precipitation map could be too high.

The net inflow and outflow of 17,000 acre-ft/yr estimated previously for Dayton Valley (Glancy and Katzer, 1976, p. 66) is similar to the low-range estimate developed in this study and about half that of the high-range estimate. The previous estimate is different from those made in this study because ground-water pumping in the area previously was minimal and a 
single value for discharge by ground-water pumping, crop consumptive use, and evapotranspiration was calculated by difference, to balance inflow and outflow. Recharge from precipitation and streamflow generated within the area could be greater if precipitation is greater than that estimated from the altitudeprecipitation relation by Glancy and Katzer (1976, p. 48), and if the Maxey-Eakin method of estimating recharge is applicable.

Uncertainties in these water-budget components could be refined by collection of additional hydrologic data on annual precipitation, subsurface flow from the mountain blocks to the basin-fill aquifers, hydraulic gradients between stream stage and the adjacent water table, streamflow gains and losses, agricultural pumping, and water levels in areas where wells are lacking. Using these data, a numerical model could be developed and used to refine (1) estimates of the complex interchange of flow between the surface-water and ground-water systems and (2) estimates of consumptive use by crops and phreatophytes as a function of depth to water.

\section{REFERENCES CITED}

Archbold, N.L., 1969, Industrial mineral deposits, in Moore, J.G., Geology and mineral deposits of Lyon, Douglas, and Ormsby Counties, Nevada: Nevada Bureau of Mines Bulletin 75, p. 31-42.

Arteaga, F.E., 1986, Mathematical model analysis of the Eagle Valley ground-water basin, west-central Nevada: Nevada Division of Water Resources, Bulletin 45, 53 p.

Arteaga, F.E., and Durbin, T.J., 1979, Development of a relation for steady-state pumping rate for Eagle Valley ground-water basin, Nevada: U.S. Geological Survey Open-File Report 79-261, 44 p.

Benson, L.V., 1978, Fluctuations in the level of Lake Lahontan during the last 40,000 years: Quaternary Research, v. 9, p. 300-318.

Bicknell, S.N., Imhoff, J.C., Kittle, J.L., Donigan, A.S., and Johanson, R.C., 1993, Hydrological simulation program-FORTRAN: Environmental Research Laboratory, User's manual for release 10EPA/600/ R-93/174, $660 \mathrm{p}$.

Bingler, E.C., 1977, New Empire geologic map: Nevada Bureau of Mines and Geology, Map 59, scale 1:24,000.

Bonham, H.F., 1969, Geology and mineral deposits of Washoe and Storey Counties, Nevada: Nevada Bureau of Mines Bulletin 70, $40 \mathrm{p}$.

Cardinalli, J.L., Roach, L.M., Rush, F.E., and Vasey, B.J., 1968, State of Nevada hydrographic areas: Nevada Division of Water Resources map, scale 1:500,000.
Clary, S.L., McClary, D.R., Whitney, Rita, and Reeves, D.D., 1995, Water resources data, Nevada, water year 1994: U.S. Geological Survey Water-Data Report NV-94-1, $768 \mathrm{p}$.

Daly, Christopher, Neilson, R.P., and Phillips, D.L., 1994, A statistical topographic model for mapping climatological precipitation over mountainous terrain: Journal of Applied Meteorology, v. 33, p. 140-158.

Eakin, T.E., 1960, Ground-water appraisal of Newark Valley, White Pine County, Nevada: Nevada Department of Conservation and Natural Resources, GroundWater Resources - Reconnaissance Report 1, 33 p.

Eakin, T.E., and Maxey, G.B., 1951, Ground water in Ruby Valley, Elko and White Pine Counties, Nevada, in Eakin, T.E., Maxey, G.B., Robinson, T.W., Fredericks, J.C., and Loeltz, O.J., Contributions to the hydrology of eastern Nevada: Nevada State Engineer, Water Resources Bulletin 12, p. 65-93.

Freeze, F.A., and Cherry, J.A., 1979, Groundwater: Englewood Cliffs, N.J., Prentice-Hall, 604 p.

Frisbie, H.R., LaCamera, R.J., Riek, M.M., and Wood, D.B., 1983, Water resources data Nevada, water year 1982: U.S. Geological Survey Water-Data Report NV-82-1, $360 \mathrm{p}$.

Glancy, P.A., and Katzer, T.L., 1976, Water-resources appraisal of the Carson River Basin, western Nevada: Nevada Division of Water Resources, Reconnaissance Report 59, $126 \mathrm{p}$.

J.H. Kleinfelder and Associates, 1985, Hydrogeological and preliminary geotechnical investigation, Eagle Valley Golf Course, Carson City, Nevada: Technical report, $31 \mathrm{p}$.

Hardman, George, 1936, Nevada precipitation and acreages of land by rainfall zones: Reno, University of Nevada Agricultural Experiment Station mimeographed report, 10 p. and map.

1965, Nevada precipitation map: Nevada Division of Conservation and Natural Resources Report, 27 p.

Hardman, George, and Mason, H.G., 1949, Irrigated lands of Nevada: Reno, University of Nevada, Agricultural Experiment Station Bulletin 183, 57 p.

Harrill, J.R., 1973, Evaluation of the water resources of Lemmon Valley, Washoe County, Nevada, with emphasis of effects of ground-water development to 1971: Nevada Division of Water Resources, Bulletin $42,130 \mathrm{p}$.

Harrill, J.R., and Moore, D.O., 1970, Effects of groundwater development on the water regimen of Paradise Valley, Humboldt County, Nevada, 1948-68, and hydrologic reconnaissance of the tributary areas: Nevada Division of Water Resources Bulletin 39, $123 \mathrm{p}$. 
Harrill, J.R., and Preissler, A.M., 1994, Ground-water flow and simulated effects of development in Stagecoach Valley, a small, partly drained basin in Lyon and Storey Counties, western Nevada: U.S. Geological Survey Professional Paper 1409-H, 74 p.

Harrill, J.R., Welch, A.H., and Preissler, A.M., 1993, Hydrochemical evidence for subsurface inflow to Stagecoach Valley, Lyon County, Nevada, in Subitzky, Seymour, ed., Selected papers in the hydrologic sciences, 1988-92: U.S. Geological Survey Water-Supply Paper 2340, p. 179-193.

Heath, R.C., 1989, Basic ground-water hydrology: U.S. Geological Survey Water-Supply Paper 2220, 84 p.

Hess, D.L., Mello, K.A., Sexton, R.J., and Young, R.L., 1993, Water resources data, Nevada, water year 1992: U.S. Geological Survey Water-Data Report NV-92-1, $511 \mathrm{p}$.

Hess, G.W., 1996, Progress report on daily flow-routing simulation for the Carson River, California and Nevada: U.S. Geological Survey Open-File Report 96-211, $41 \mathrm{p}$.

Iman, R.L, and Conover, W.J., 1983, A modern approach to statistics: New York, John Wiley, 497 p.

James, J.W., 1995, Nevada climate summary, August 1995: Office of the State Climatologist, v. 12, no. 8, 4 p.

Lumos \& Associates, Inc., and Watersource, Inc., 1986, Well completion/evaluation reports for Carson City comprehensive water plan, water source development (Task Order 4.2): 8 numbered sections.

Lyon County Planning Commission and Master-Plan Task Force, 1990, Lyon County master plan: Yerington, Nev., Lyon County report, 259 p.

Maurer, D.K., Berger, D.L., and Prudic D.E., 1996, Subsurface flow to Eagle Valley from Vicee, Ash, and Kings Canyons, Carson City, Nevada, estimated from Darcy's Law and the chloride-balance method: U.S. Geological Survey Water-Resources Investigations Report 96-4088, 74 p.

Maxey, G.B., and Eakin, T.E., 1949, Ground water in White River Valley, White Pine, Nye, and Lincoln Counties, Nevada: Nevada State Engineer, Water Resources Bulletin 8, $59 \mathrm{p}$.

Moore, J.G., 1969, Geology and mineral deposits of Lyon, Douglas, and Ormsby Counties, Nevada: Nevada Bureau of Mines Bulletin 75, $42 \mathrm{p}$.
Morrison, R.B., 1991, Quaternary stratigraphic, hydrologic, and climatic history of the Great Basin, with emphasis on Lakes Lahontan, Bonneville, and Tecopa, in Morrison, R.B., ed., The geology of North America, Quaternary nonglacial geology-Conterminous U.S.: Geological Society of America, v. K-2, p. 283-320.

Nichols, W.D., 1994, Groundwater discharge by phreatophyte shrubs in the Great Basin as related to depth to groundwater: Water Resources Research, v. 30, no. 12, p. 3265-3274.

Owenby, J.R., and Ezell, D.S., 1992, Monthly station normals of temperature, precipitation, and heating and cooling degree days, 1961-1990, Nevada: National Climatic Data Center, Climatography of the United States no. $81,20 \mathrm{p}$.

Prudic, D.E., and Wood, J.L., 1995, Results of hypothetical ground-water pumping in Carson Valley, a riverdominated basin in Douglas County, Nevada, and Alpine County, California: U.S. Geological Survey Water-Resources Investigations Report 95-4174, 29 p.

Pupacko, A., LaCamera, R.J., Riek, M.M., and Wood D.B., 1988, Water resources data, Nevada, water year 1986: U.S. Geological Survey Water-Data Report NV-86-1, $263 \mathrm{p}$.

Rogers, D.K., 1975, Environmental geology of northern Carson City, Nevada: University of Nevada, Reno, unpublished M.S. thesis, $133 \mathrm{p}$.

Rush, F.E., 1968, Index of hydrographic areas in Nevada: Nevada Division of Water Resources, Information Report 6, $38 \mathrm{p}$.

Schaefer, D.H., and Whitney, Rita, 1992, Geologic framework and ground-water conditions in basin-fill aquifers of the Dayton Valley and Churchill Valley Hydrographic Areas, western Nevada: U.S. Geological Survey Water-Resources Investigations Report 91-4072, $12 \mathrm{p}$.

Shamberger, H.A., 1972, The story of the water supply for the Comstock: U.S. Geological Survey Professional Paper 779, $53 \mathrm{p}$.

Shawe, D.R., 1965, Strike-slip control of basin-range structure indicated by historical faults in western Nevada: Geological Society of America Bulletin, v. 76, p. 1361-1378.

Spane, F.A., Jr., 1977, Evaluation of factors influencing the inorganic water-quality regimen of Carson River, Carson Valley, Nevada-California: University of Nevada, Reno, unpublished Ph.D. thesis, 205 p.

Stewart, J.H., 1980, Geology of Nevada-A discussion to accompany the geologic map of Nevada: Nevada Bureau of Mines and Geology Special Publication 4, $136 \mathrm{p}$. 
Thomas, J.M., and Lawrence, S.J., 1994, Ground-water quality and geochemistry in Dayton, Stagecoach, and Churchill Valleys, Western Nevada: U.S. Geological Survey Open-File Report 93-356, 69 p.

Thomasson, H.G., Jr., Olmsted, F.H., and LeRoux, E.F., 1960, Geology, water resources, and usable groundwater storage capacity of part of Solano County, California: U.S. Geological Survey Water-Supply Paper 1464, 693 p.

Thompson, G.A., 1956, Geology of the Virginia City quadrangle, Nevada: U.S. Geological Survey Bulletin 1042-C, 77 p.

Trexler, D.T., Koenig, B.A., Flynn, T., and Bruce, J.L., [1980?], Assessment of the geothermal resources of Carson-Eagle Valleys and Big Smoky Valley, Nevada: Nevada Bureau of Mines and Geology, First Annual Report, May 1, 1979 - May 1980, DOE/NV/10039-2, $162 \mathrm{p}$.
U.S. Geological Survey, 1972, Water resources data for Nevada, 1971: U.S. Geological Survey water data report, $239 \mathrm{p}$.

1974, Surface water supply of the United States, 1966-70-Part 10. The Great Basin: U.S. Geological Survey Water-Supply Paper 2127, 1143 p.

U.S. Soil Conservation Service, 1992, Nevada irrigation guide: U.S. Soil Conservation Service, 11 numbered chapters.

Watson, P., Sinclair, P., and Waggoner, R., 1976, Quantitative evaluation of a method for estimating recharge to desert basins of Nevada: Journal of Hydrology, v. 31, p. 335-357.

Worts, G.F., Jr, and Malmberg, G.T., 1966, Hydrologic appraisal of Eagle Valley, Ormsby County, Nevada: Nevada Department of Conservation and Natural Resources, Water-Resources - Reconnaissance Report $39,55 \mathrm{p}$. 
Appendix 1. Ground-water recharge estimated from precipitation-altitude relations for subbasins of the Dayton Valley Hydrographic Area, Nevada

[Mean annual precipitation estimated by three methods: Glancy and Katzer (1976, p. 48), distance-altitude relation, and 1996 Nevada precipitation map. For calculations using altitude-precipitation relation of Glancy and Katzer (1976, p.48) and 1996 Nevada precipitation map, average precipitation for range is used to calculate total precipitation; for distance-altitude relation, average precipitation is calculated as total precipitation divided by area. Area rounded to three significant figures; precipitation and recharge rounded to two significant figures. Symbols: $<$, less than; $>$, greater than]

\begin{tabular}{ccccccc}
\hline $\begin{array}{c}\text { Altitude zone } \\
\text { (feet above } \\
\text { sea level) }\end{array}$ & $\begin{array}{c}\text { Range } \\
\text { (inches) }\end{array}$ & $\begin{array}{c}\text { Average } \\
\text { (feet) }\end{array}$ & $\begin{array}{c}\text { Area of altitude } \\
\text { zone or } \\
\text { precipitation } \\
\text { range } \\
\text { (acres) }\end{array}$ & $\begin{array}{c}\text { Estimated } \\
\text { precipitation } \\
\text { (acre-feet) }\end{array}$ & $\begin{array}{c}\text { Recharge from } \\
\text { precipitation } \\
\text { and streamflow } \\
\text { (percent) }\end{array}$ & $\begin{array}{c}\text { Estimated } \\
\text { recharge } \\
\text { (acre-feet) }\end{array}$ \\
\hline
\end{tabular}

Riverview Subbasin

Precipitation estimated from altitude-precipitation relation of Glancy and Katzer (1976, p. 48) using digital elevation model

\begin{tabular}{crrrrrr}
$6,000-7,000$ & $12-15$ & 1.1 & 1,430 & 1,600 & 7 & 110 \\
$5,000-6,000$ & $8-12$ & 0.8 & 5,650 & 4,500 & 3 & 140 \\
$<5,000$ & $<8$ & 0.5 & 6,050 & 3,000 & minor & 0 \\
\cline { 2 - 7 } tal (rounded) & & 13,100 & 9,100 & & &
\end{tabular}

Precipitation estimated from distance-altitude relation

Percent increase from Glancy and Katzer (1976)

\begin{tabular}{lrrrr} 
de relation & & & & \\
1.3 & 170 & 220 & 15 & 33 \\
1.1 & 1,980 & 2,200 & 7 & 150 \\
0.8 & 11,000 & 8,800 & 3 & 260 \\
\hline & 13,200 & 11,000 & & 440 \\
$976)$ & & 21 & & 76
\end{tabular}

Precipitation estimated from 1996 Nevada precipitation map

Percent increase from Glancy and Katzer (1976)

\begin{tabular}{rrrrr}
$r$ & & & \\
1.3 & 6,100 & 7,900 & 15 & 1,200 \\
1.1 & 2,300 & 2,500 & 7 & 180 \\
0.8 & 4,370 & 3,500 & 3 & 100 \\
\hline & 12,800 & 14,000 & & 1,500 \\
$976)$ & & 54 & & 500
\end{tabular}

Mound House Subbasin

Precipitation estimated from altitude-precipitation relation of Glancy and Katzer (1976, p. 48) using digital elevation model

\begin{tabular}{crrrrrr}
$7,000-8,000$ & $15-20$ & 1.5 & 154 & 230 & 15 & 35 \\
$6,000-7,000$ & $12-15$ & 1.1 & 4,940 & 5,400 & 7 & 380 \\
$5,000-6,000$ & $8-12$ & 0.8 & 12,500 & 10,000 & 3 & 300 \\
$<5,000$ & $<8$ & 0.5 & 6,960 & 3,500 & minor & 0 \\
\cline { 2 - 7 } tal (rounded) & & 24,600 & 19,000 & & & 720
\end{tabular}

Precipitation estimated from distance-altitude relation

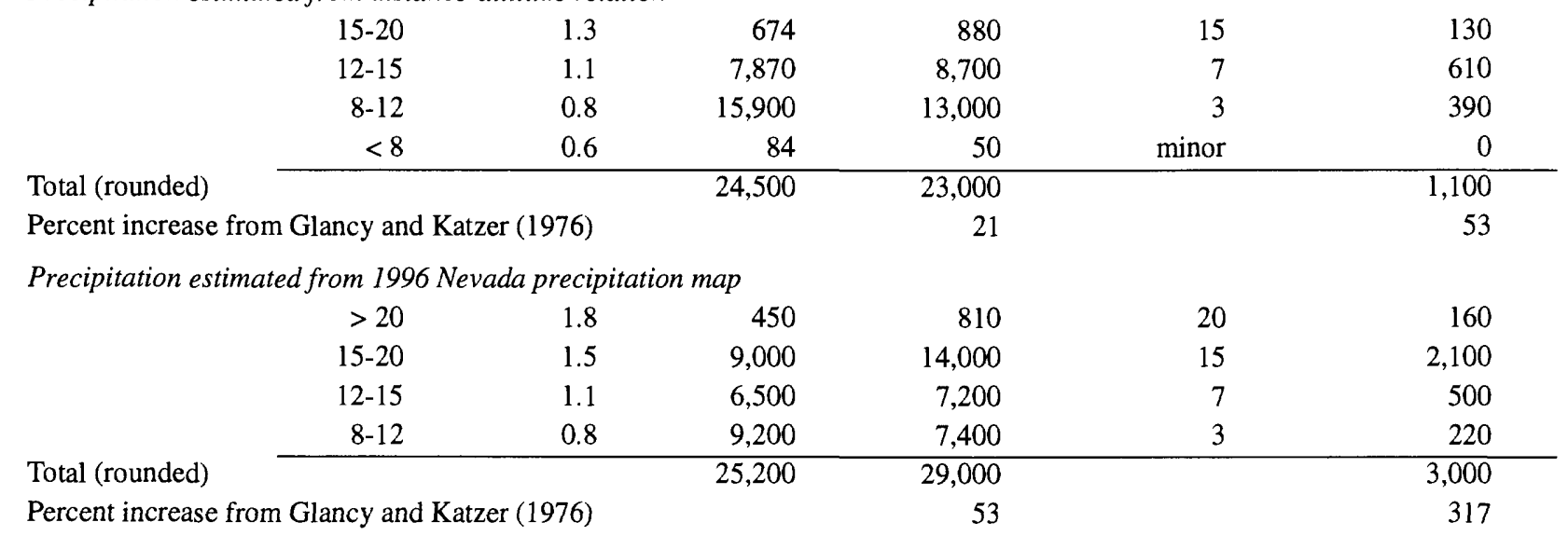


Appendix 1. Ground-water recharge estimated from precipitation-altitude relations for subbasins of the Dayton Valley Hydrographic Area, Nevada-Continued

\begin{tabular}{ccccccc}
\hline $\begin{array}{c}\text { Altitude zone } \\
\text { (feet above } \\
\text { sea level) }\end{array}$ & $\begin{array}{c}\text { Range } \\
\text { (inches) }\end{array}$ & $\begin{array}{c}\text { Average } \\
\text { (feet) }\end{array}$ & $\begin{array}{c}\text { Area of altitude } \\
\text { zone or } \\
\text { precipitation } \\
\text { range } \\
\text { (acres) }\end{array}$ & $\begin{array}{c}\text { Estimated } \\
\text { precipitation } \\
\text { (acre-feet) }\end{array}$ & $\begin{array}{c}\text { Recharge from } \\
\text { precipitation } \\
\text { and streamflow } \\
\text { (percent) }\end{array}$ & $\begin{array}{c}\text { Estimated } \\
\text { recharge } \\
\text { (acre-feet) }\end{array}$ \\
\hline
\end{tabular}

\section{Carson Plains Subbasin}

Precipitation estimated from altitude-precipitation relation of Glancy and Katzer (1976, p. 48) using digital elevation model

\begin{tabular}{crrrrrr}
$8,000-9,000$ & $>20$ & 1.8 & 700 & 1,300 & 20 & 260 \\
$7,000-8,000$ & $15-20$ & 1.5 & 8,370 & 13,000 & 15 & 2,000 \\
$6,000-7,000$ & $12-15$ & 1.1 & 27,100 & 30,000 & 7 & 2,100 \\
$5,000-6,000$ & $8-12$ & 0.8 & 33,000 & 26,000 & 3 & 780 \\
$<5,000$ & $<8$ & 0.5 & 38,600 & 19,000 & minor & 0 \\
\cline { 2 - 6 } al (rounded) & & 108,000 & 89,000 & & & 5,100
\end{tabular}

Total (rounded)

5,100

Precipitation estimated from distance-altitude relation

Percent increase from Glancy and Katzer (1976)

\begin{tabular}{rrrrr}
1.7 & 176 & 300 & 20 & 60 \\
1.4 & 16,300 & 23,000 & 15 & 3,500 \\
1.1 & 28,800 & 32,000 & 7 & 2,200 \\
0.8 & 41,000 & 33,000 & 3 & 990 \\
0.6 & 21,600 & 13,000 & minor & 0 \\
\hline & 108,000 & 101,000 & & 6,800 \\
$976)$ & & 13 & & 33
\end{tabular}

Precipitation estimated from 1996 Nevada precipitation map

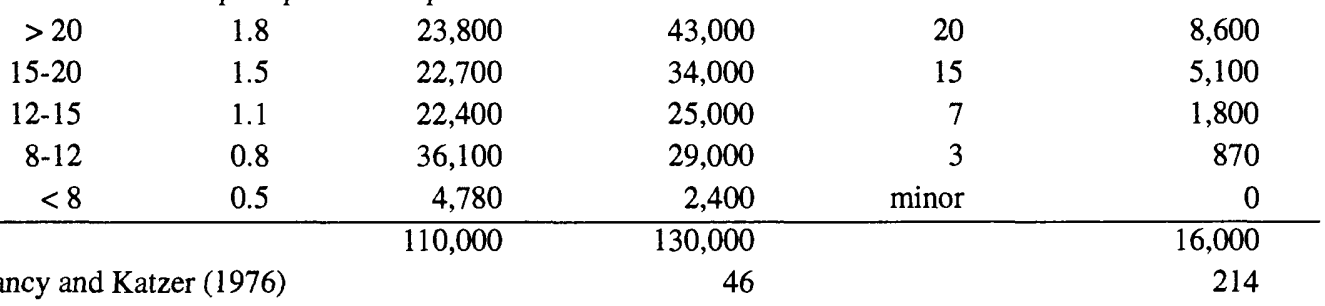

Total (rounded)

Stagecoach Subbasin

Precipitation estimated from altitude-precipitation relation of Glancy and Katzer (1976, p. 48) using digital elevation model

\begin{tabular}{crrrrrr}
$7,000-8,000$ & $15-20$ & 1.5 & 12 & 18 & 15 & 3 \\
$6,000-7,000$ & $12-15$ & 1.1 & 4,620 & 5,100 & 7 & 360 \\
$5,000-6,000$ & $8-12$ & 0.8 & 8,160 & 6,500 & 3 & 200 \\
$<5,000$ & $<8$ & 0.5 & 32,300 & 16,000 & minor & 0 \\
\cline { 2 - 7 } & & 45,100 & 28,000 & & & 560
\end{tabular}

Precipitation estimated from distance-altitude relation

Percent increase from Glancy and Katzer (1976)

$15-20$

1.1

170
5,310

220

33

$12-15$

14,600

5,800

410

8-12

0.8

12,000

360

$<8$

25,000

15,000

45,100

33,000

800

43

Precipitation estimated from 1996 Nevada precipitation map

$\begin{array}{lrrrrrr} & 15-20 & 1.5 & 3,500 & 5,300 & 15 & 800 \\ & 12-15 & 1.1 & 5,070 & 5,600 & 7 & 390 \\ & 8-12 & 0.8 & 13,500 & 11,000 & 3 & 330 \\ & <8 & 0.5 & 22,200 & 11,000 & \text { minor } & 0 \\ \text { Total (rounded) } & & 44,300 & 33,000 & & 1,500 \\ \text { Percent increase from Glancy and Katzer (1976) } & & & 18 & \end{array}$


Appendix 1. Ground-water recharge estimated from precipitation-altitude relations for subbasins of the Dayton Valley Hydrographic Area, Nevada-Continued

\begin{tabular}{|c|c|c|c|c|c|c|}
\hline \multirow{2}{*}{$\begin{array}{l}\text { Altitude zone } \\
\text { (feet above } \\
\text { sea level) }\end{array}$} & \multicolumn{2}{|c|}{ Precipitation } & \multirow{2}{*}{$\begin{array}{l}\text { Area of altitude } \\
\text { zone or } \\
\text { precipitation } \\
\text { range } \\
\text { (acres) }\end{array}$} & \multirow{2}{*}{$\begin{array}{c}\text { Estimated } \\
\text { precipitation } \\
\text { (acre-feet) }\end{array}$} & \multirow{2}{*}{$\begin{array}{l}\text { Recharge from } \\
\text { precipitation } \\
\text { and streamflow } \\
\text { (percent) }\end{array}$} & \multirow{2}{*}{$\begin{array}{l}\text { Estimated } \\
\text { recharge } \\
\text { (acre-feet) }\end{array}$} \\
\hline & $\begin{array}{c}\text { Range } \\
\text { (inches) }\end{array}$ & $\begin{array}{c}\text { Average } \\
\text { (feet) }\end{array}$ & & & & \\
\hline \multicolumn{7}{|c|}{ Bull Canyon Subbasin } \\
\hline \multicolumn{7}{|c|}{ Precipitation estimated from altitude-precipitation relation of Glancy and Katzer $(1976, p .48)$ using digital elevation model } \\
\hline $8,000-9,000$ & $>20$ & 1.8 & 42 & 76 & 20 & 15 \\
\hline $7,000-8,000$ & $15-20$ & 1.5 & 1,500 & 2,300 & 15 & 350 \\
\hline $6,000-7,000$ & $12-15$ & 1.1 & 5,550 & 6,100 & 7 & 430 \\
\hline $5,000-6,000$ & $8-12$ & 0.8 & 14,900 & 12,000 & 3 & 360 \\
\hline$<5,000$ & $<8$ & 0.5 & 21,400 & 11,000 & minor & 0 \\
\hline Total (rounded) & & & 43,000 & 31,000 & & 1,200 \\
\hline \multicolumn{7}{|c|}{ Precipitation estimated from distance-altitude relation } \\
\hline & $15-20$ & 1.4 & 1,970 & 2,800 & 15 & 420 \\
\hline & $12-15$ & 1.1 & 6,840 & 7,500 & 7 & 530 \\
\hline & $8-12$ & 0.8 & 19,800 & 16,000 & 3 & 480 \\
\hline & $<8$ & 0.6 & 14,900 & 8,900 & minor & 0 \\
\hline Total (rounded) & & & 43,500 & 35,000 & & 1,400 \\
\hline Percent increase fr & Slancy and & er (1976) & & 13 & & 17 \\
\hline \multicolumn{7}{|c|}{ Precipitation estimated from 1996 Nevada precipitation map } \\
\hline & $>20$ & 1.8 & 4,950 & 8,900 & 20 & 1,800 \\
\hline & $15-20$ & 1.5 & 5,320 & 8,000 & 15 & 1,200 \\
\hline & $12-15$ & 1.1 & 5,110 & 5,600 & 7 & 390 \\
\hline & $8-12$ & 0.8 & 13,500 & 11,000 & 3 & 330 \\
\hline & $<8$ & 0.5 & 14,300 & 7,200 & minor & 0 \\
\hline Total (rounded) & & & 43,200 & 41,000 & & 3,700 \\
\hline \multicolumn{4}{|c|}{ Percent increase from Glancy and Katzer (1976) } & 32 & & 208 \\
\hline
\end{tabular}




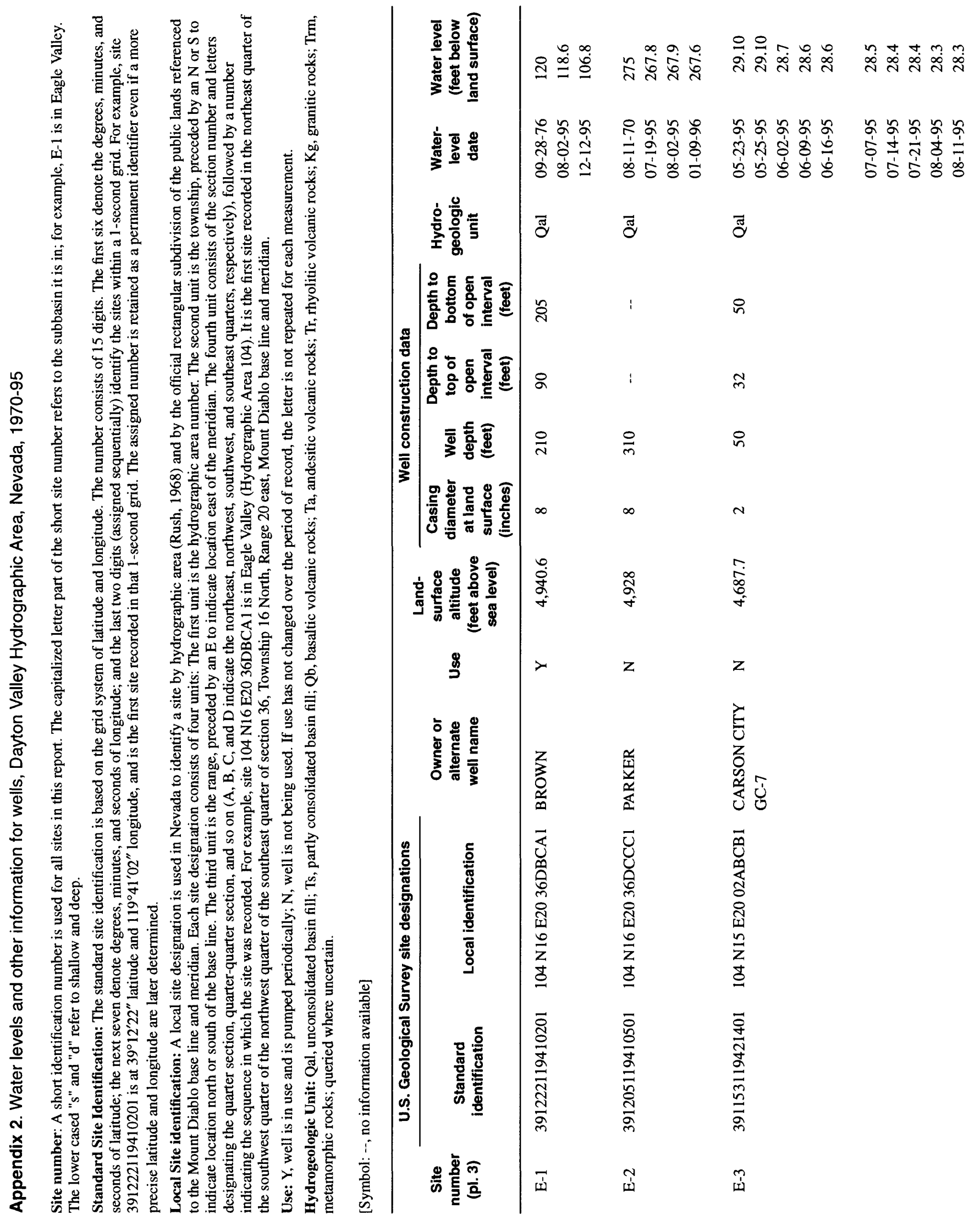




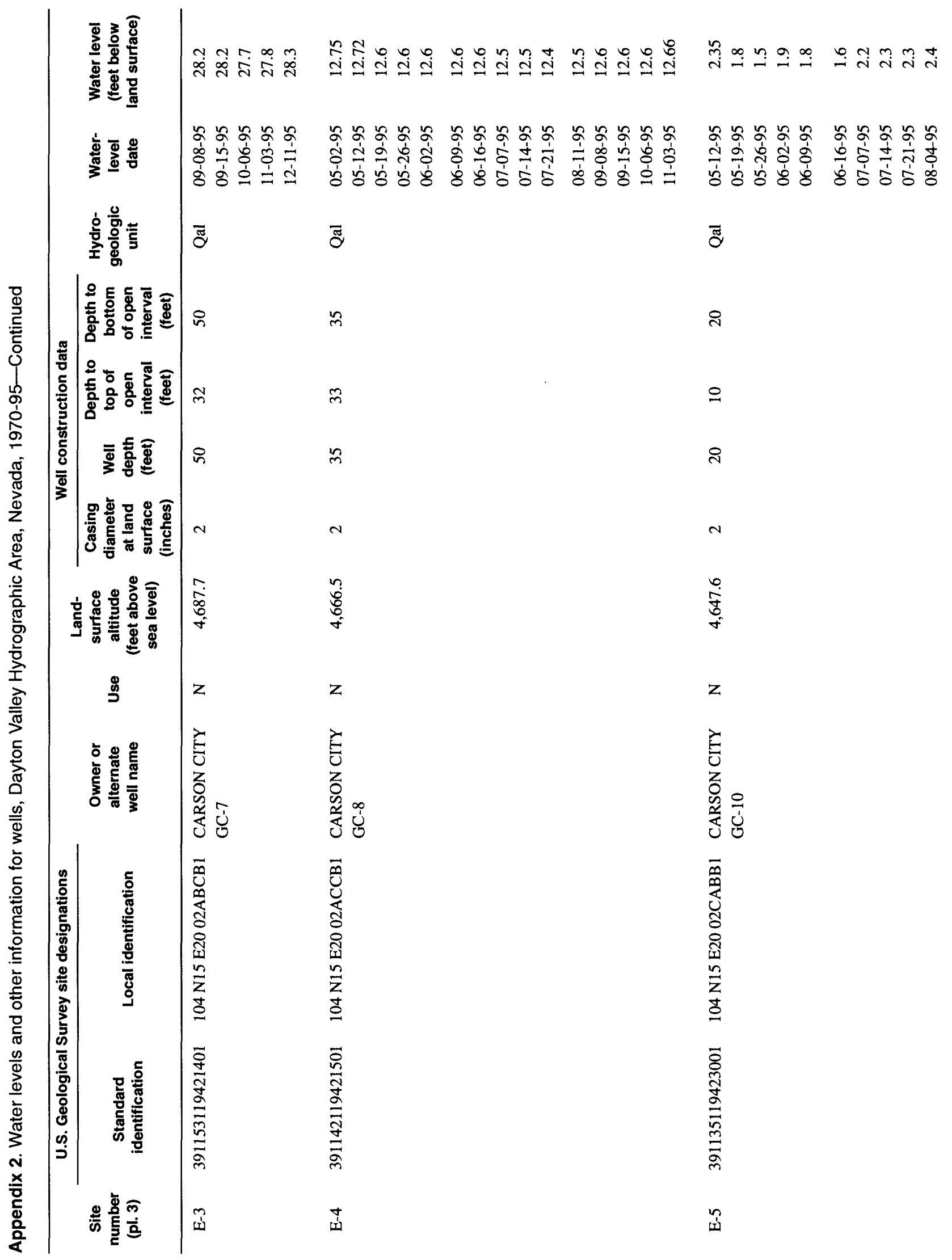




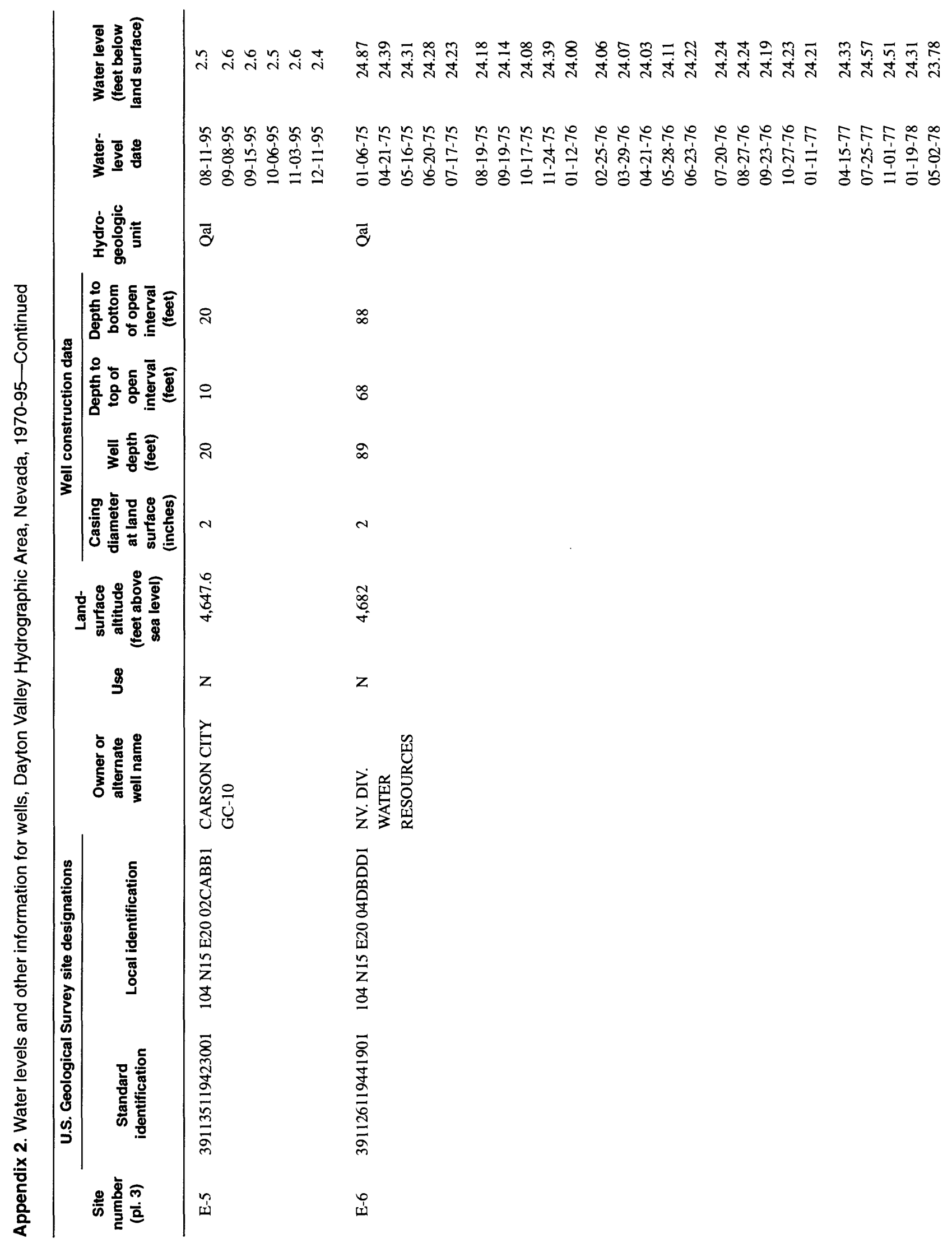




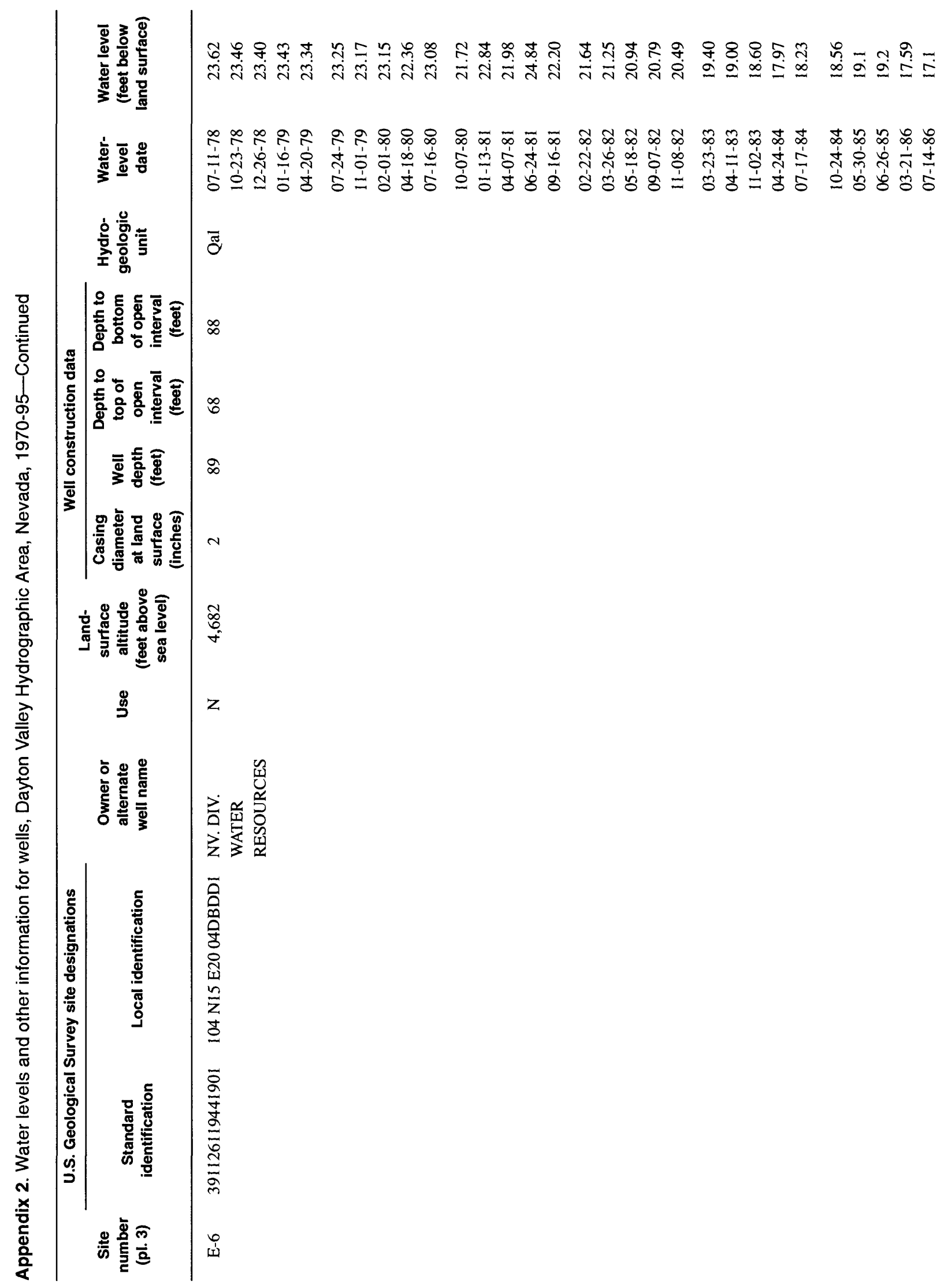




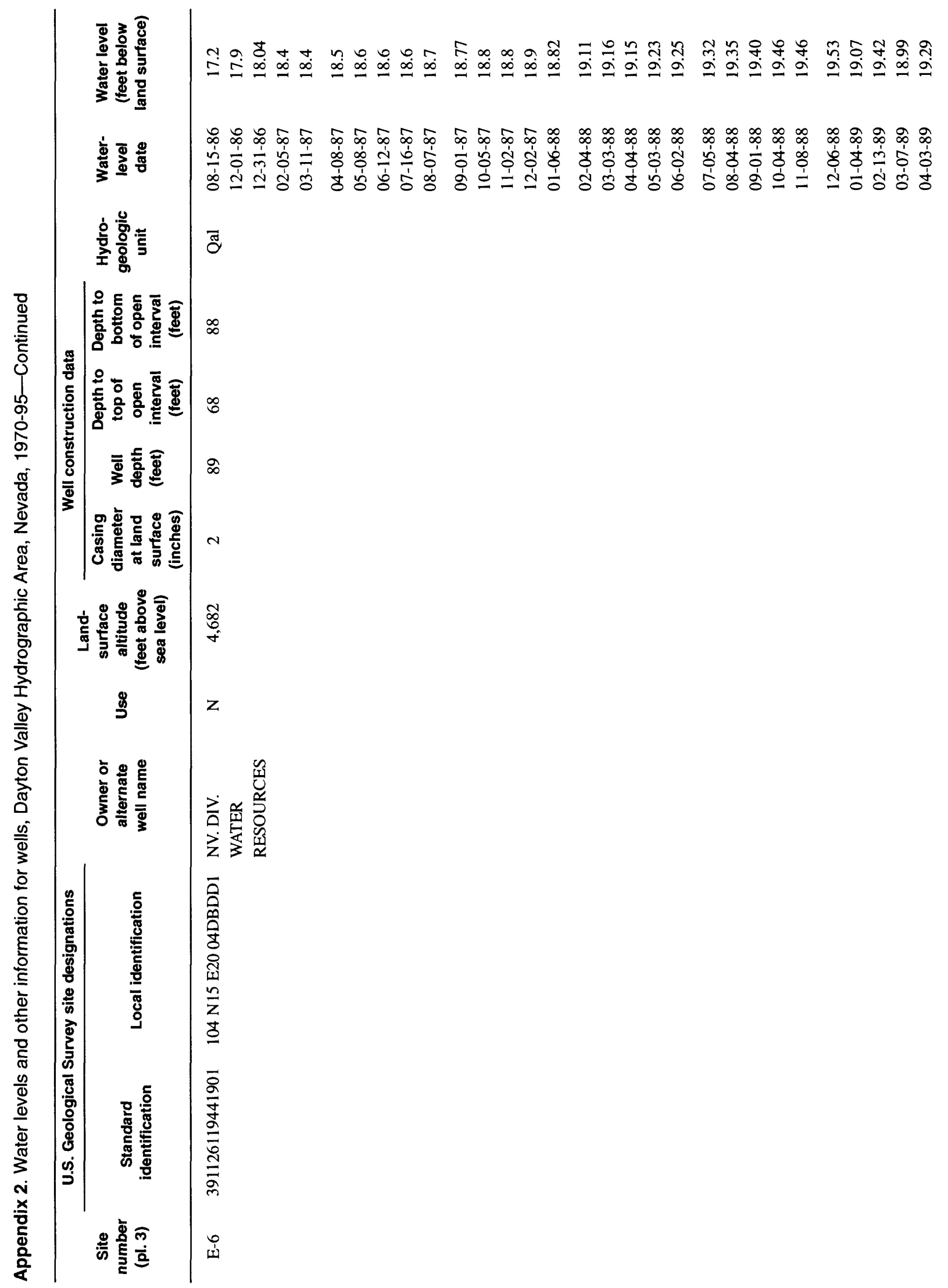




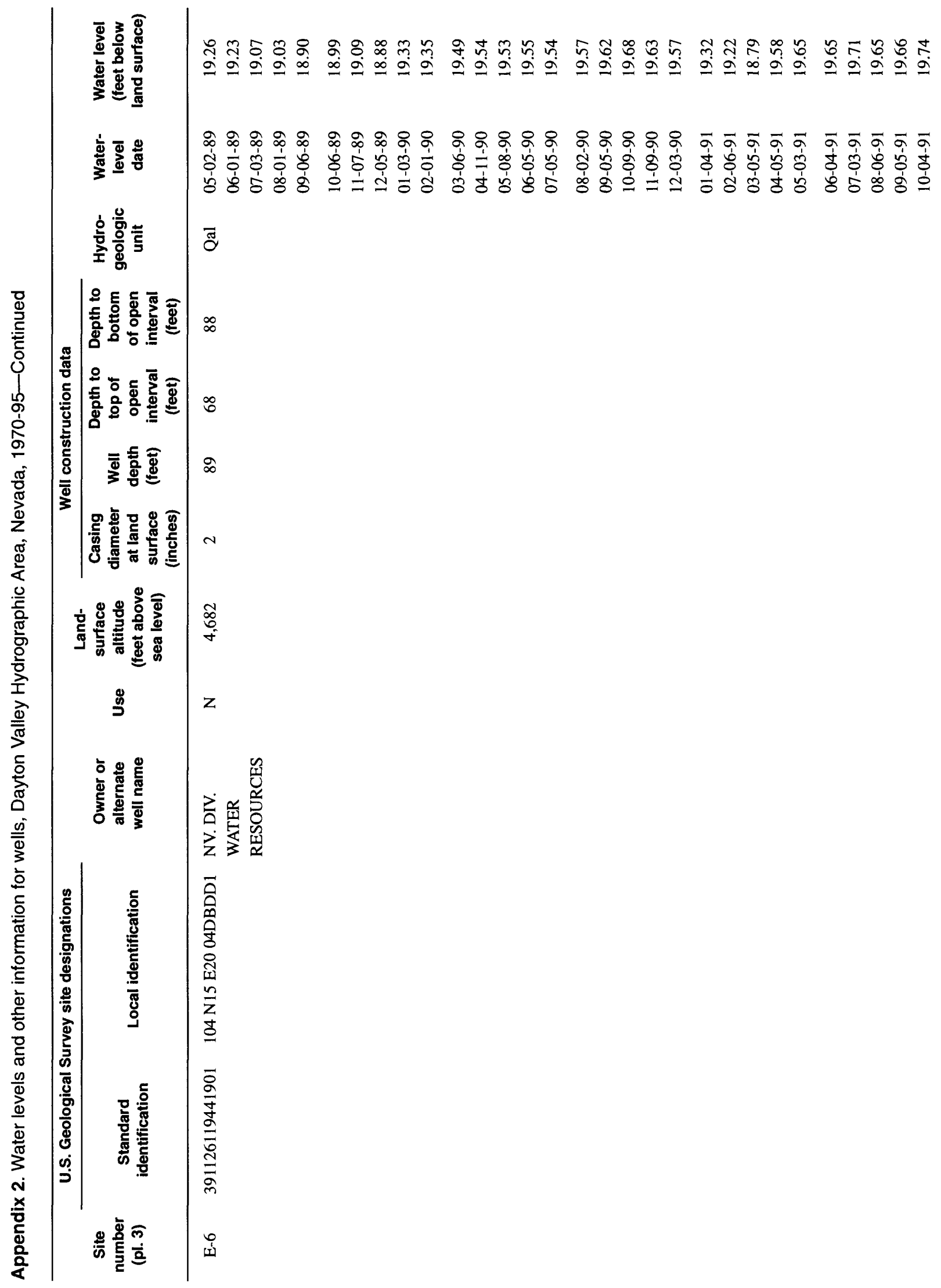




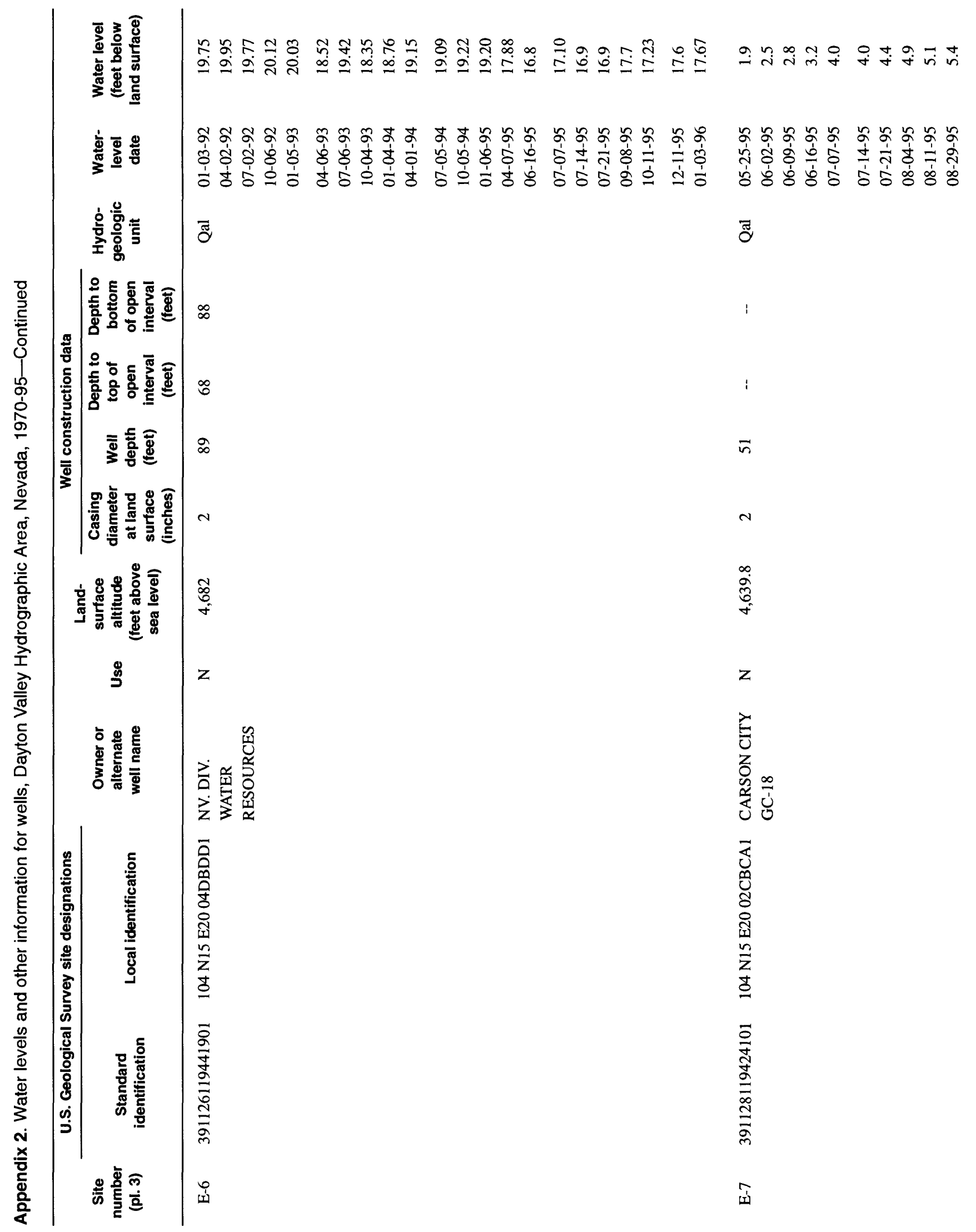




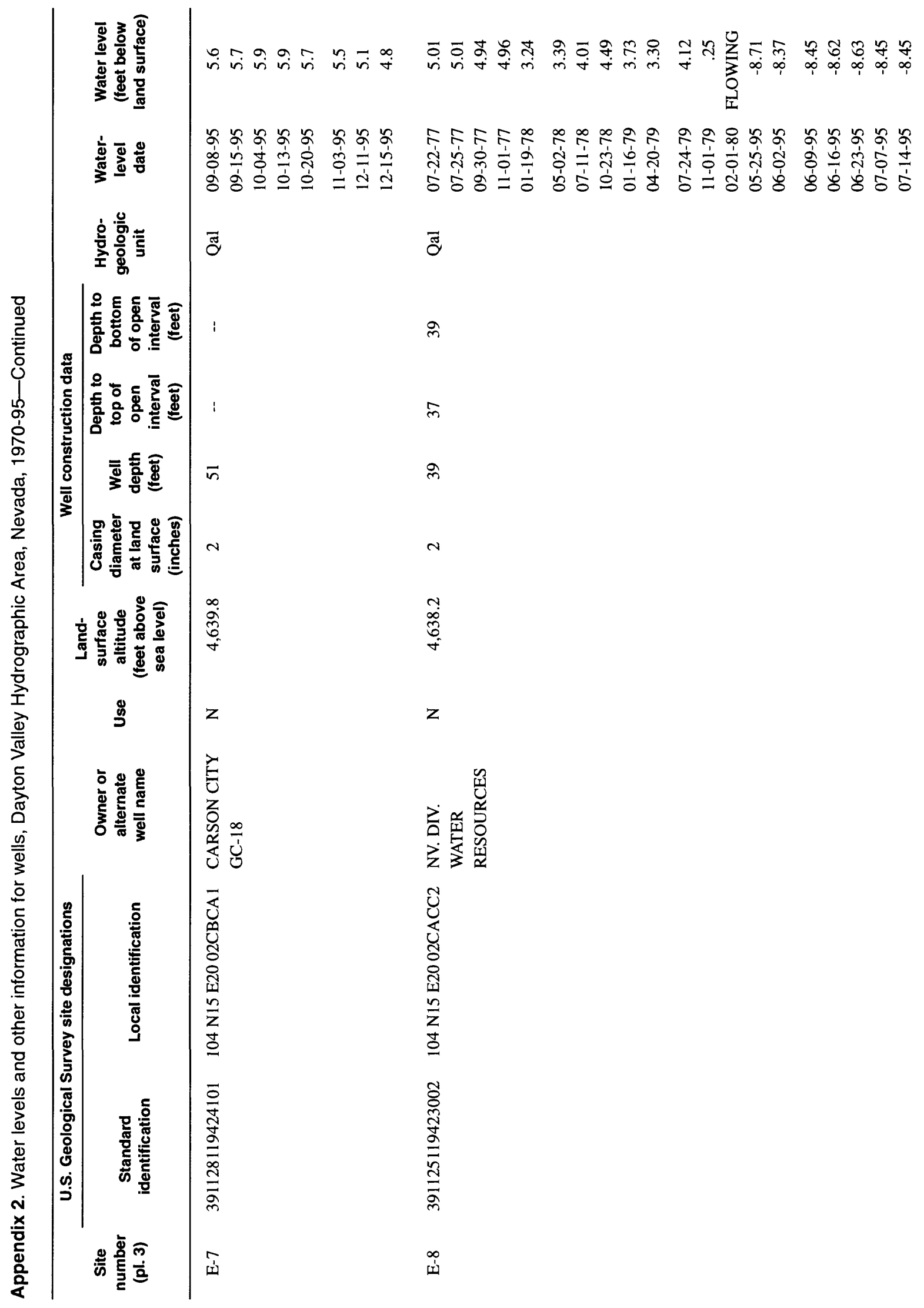




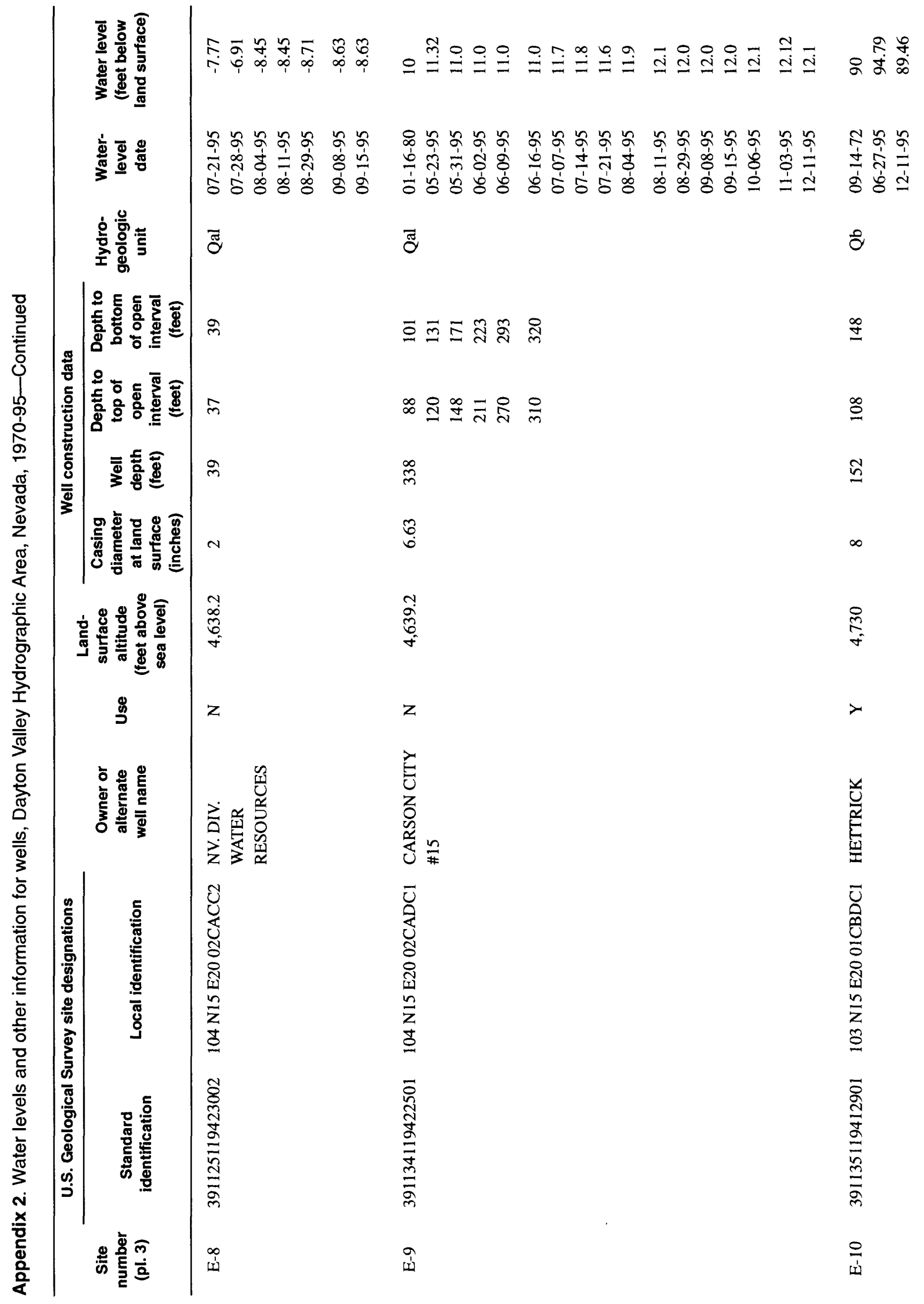




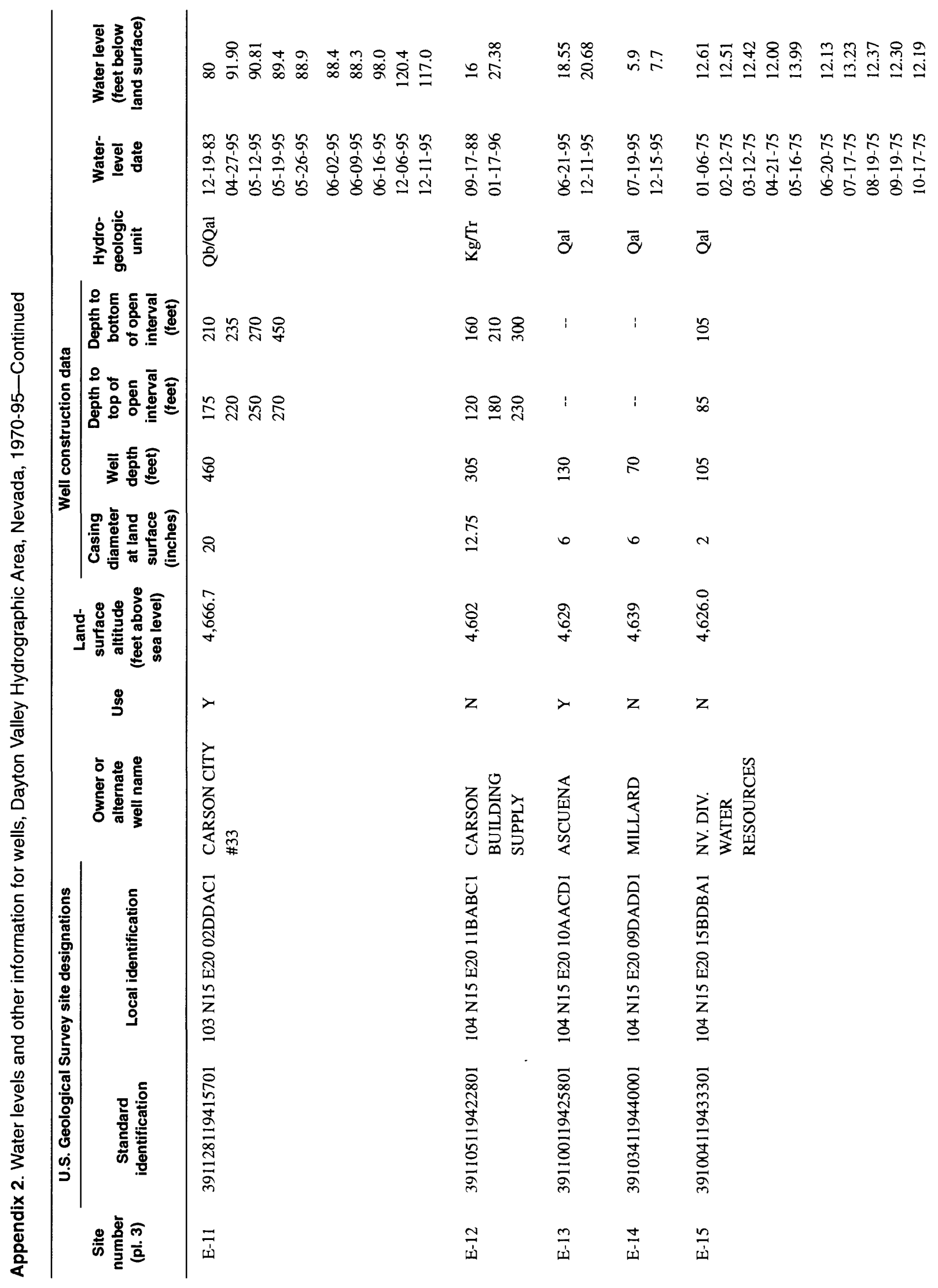




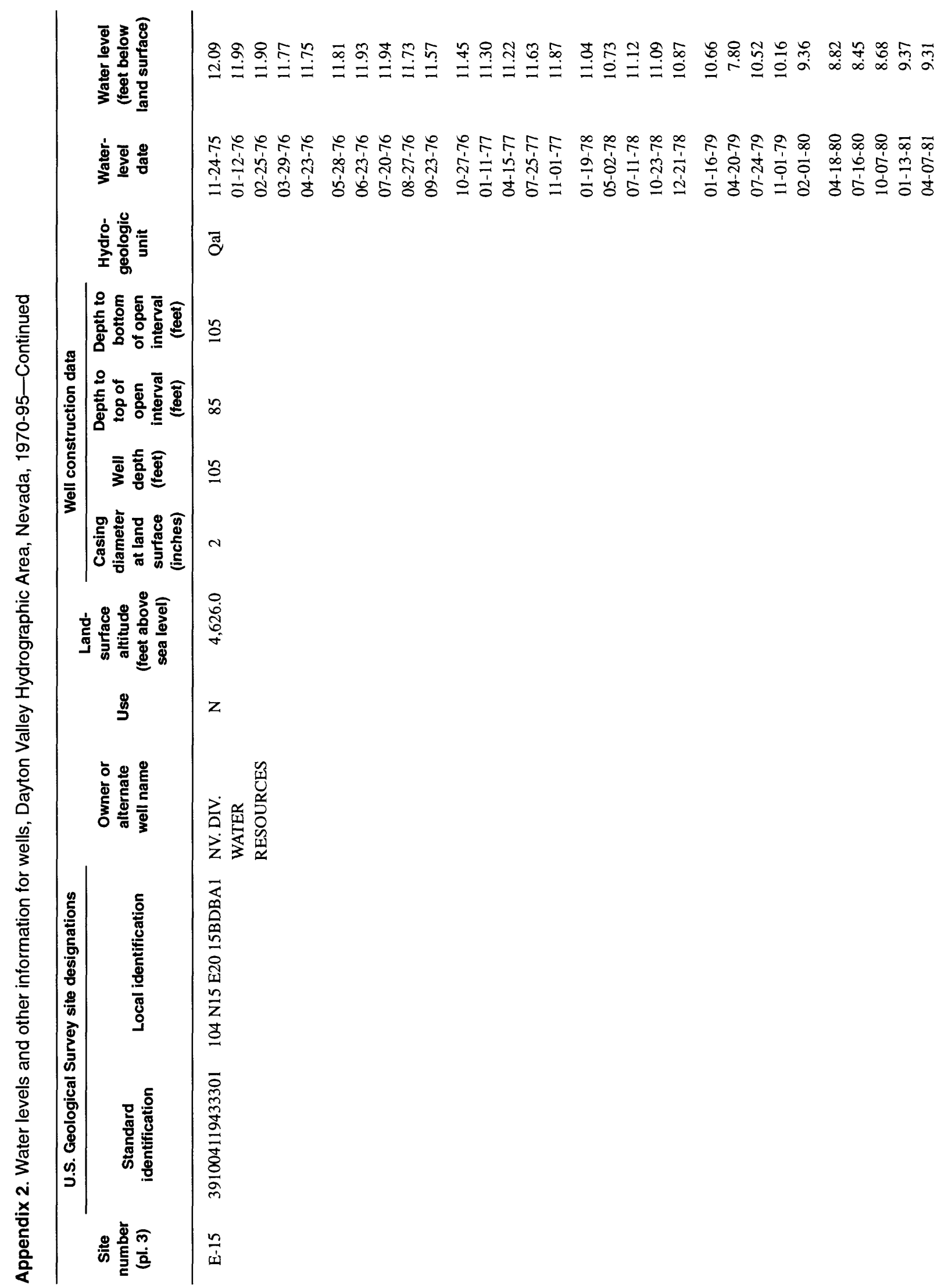




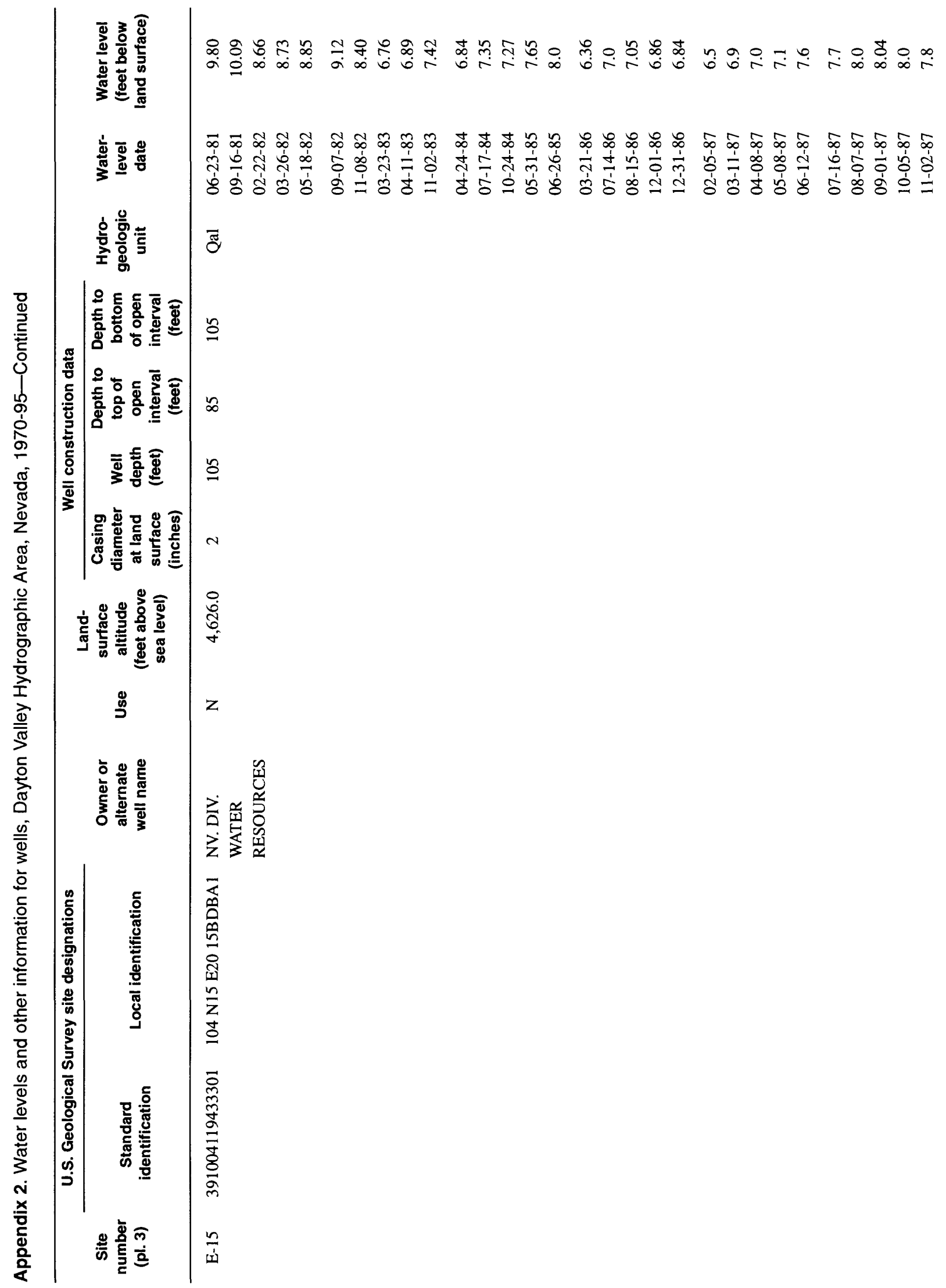




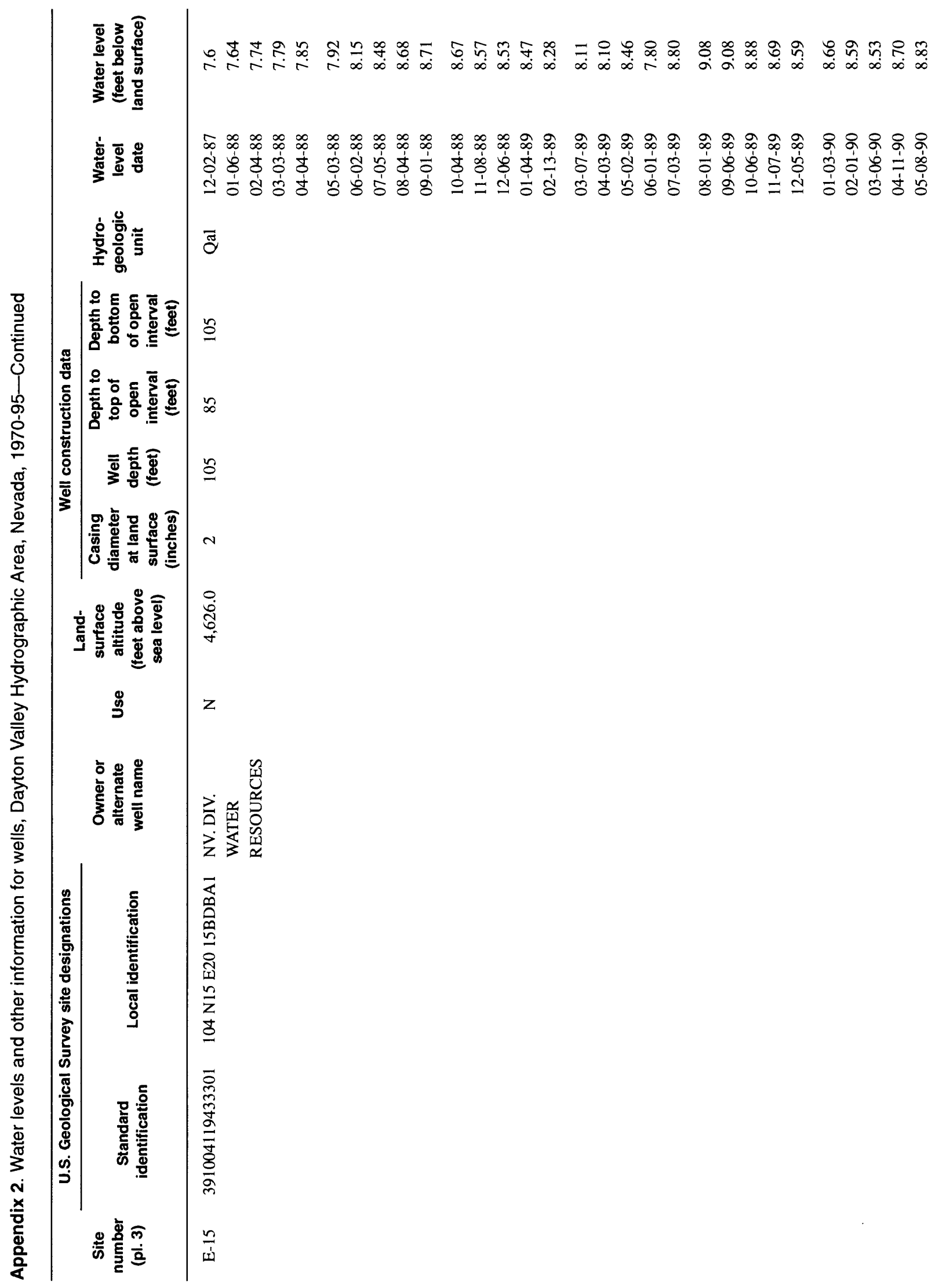




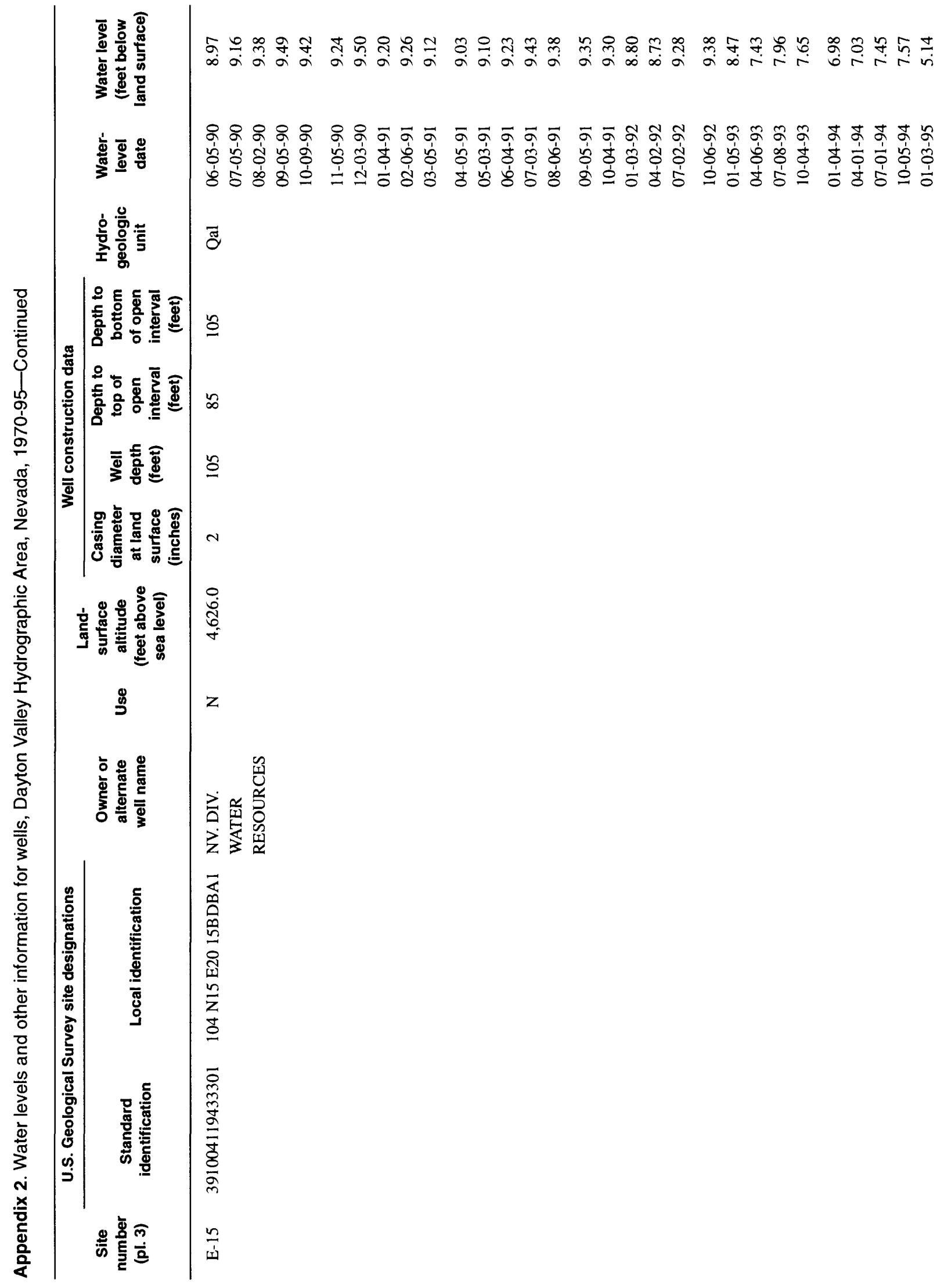




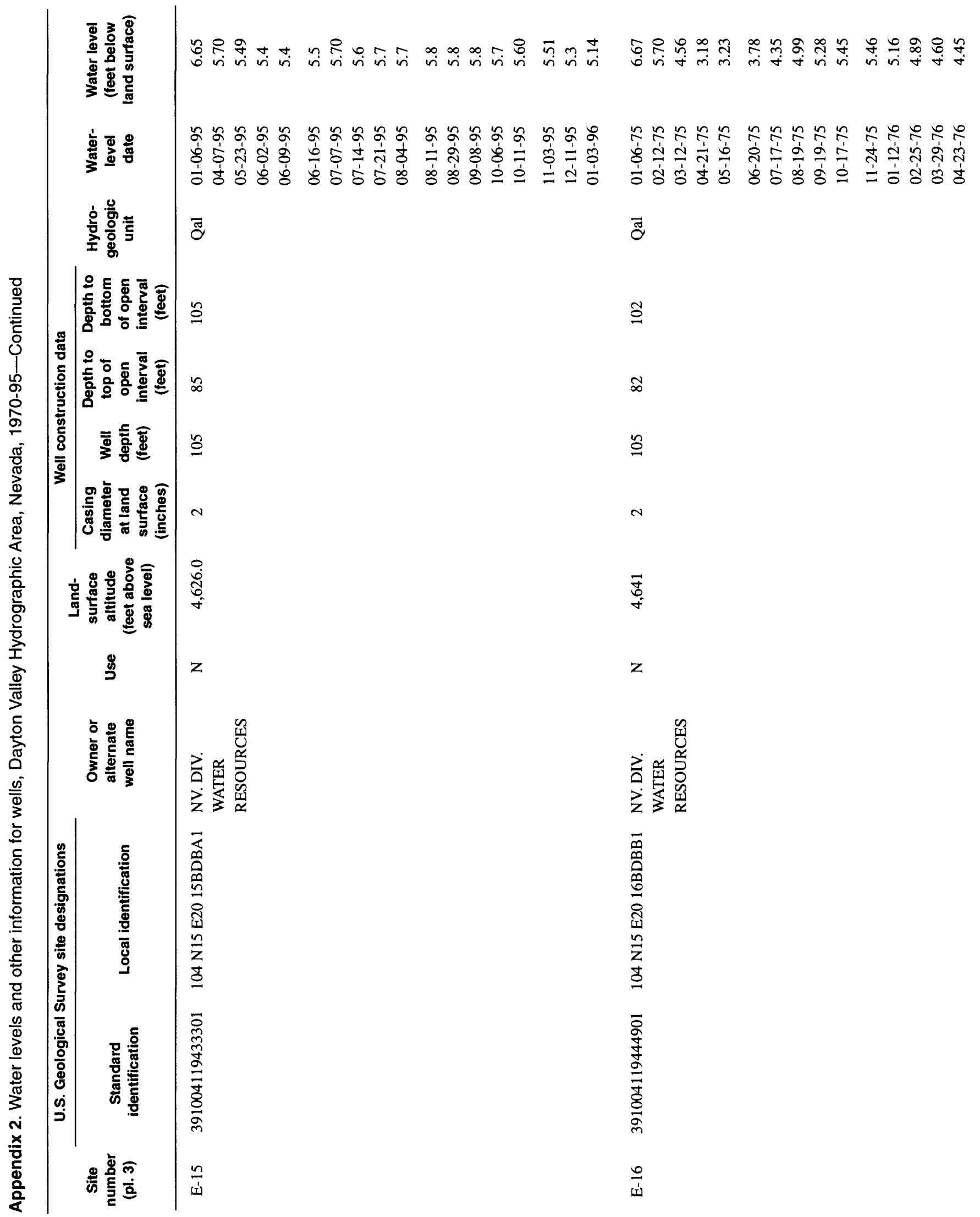




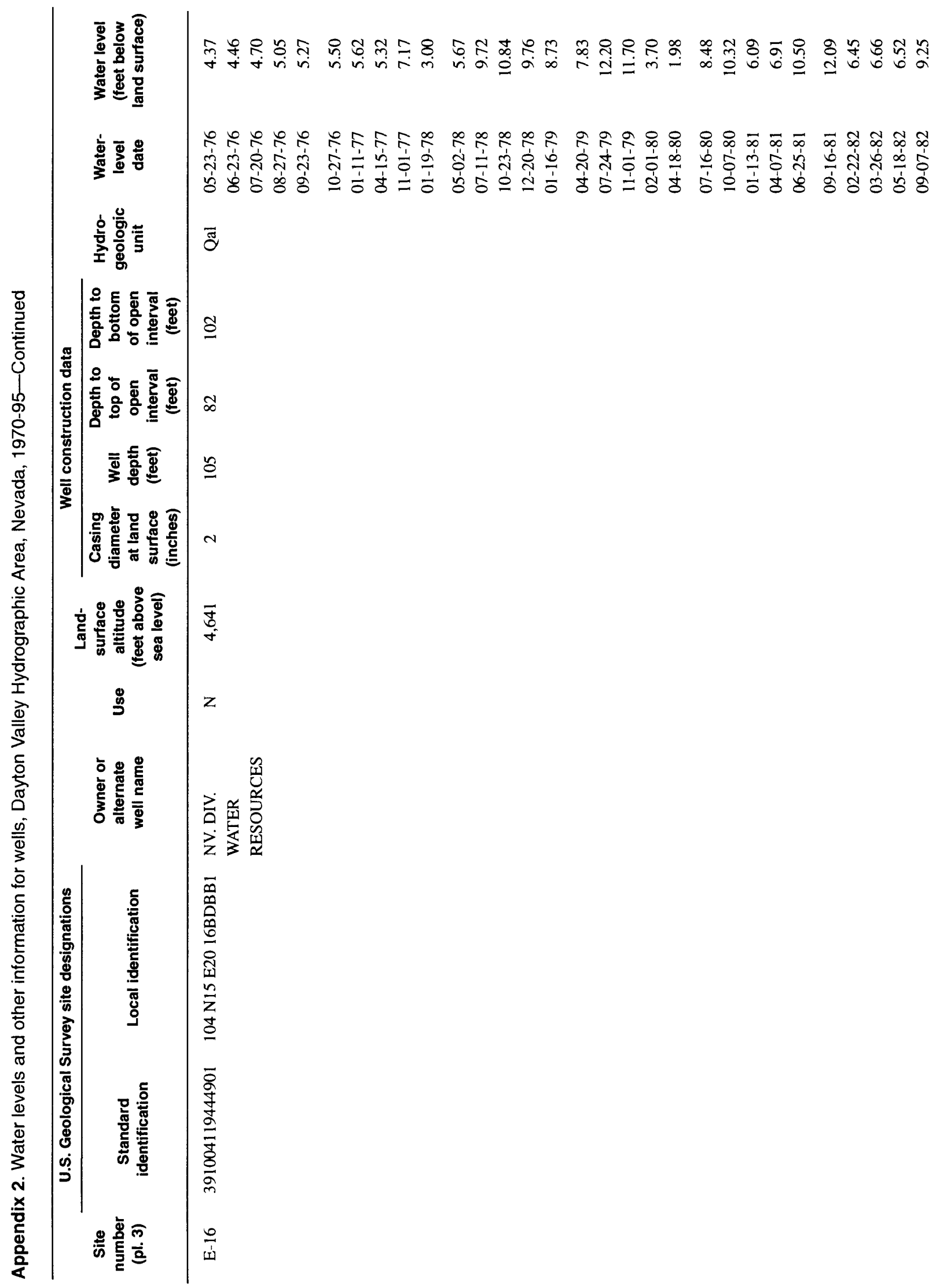




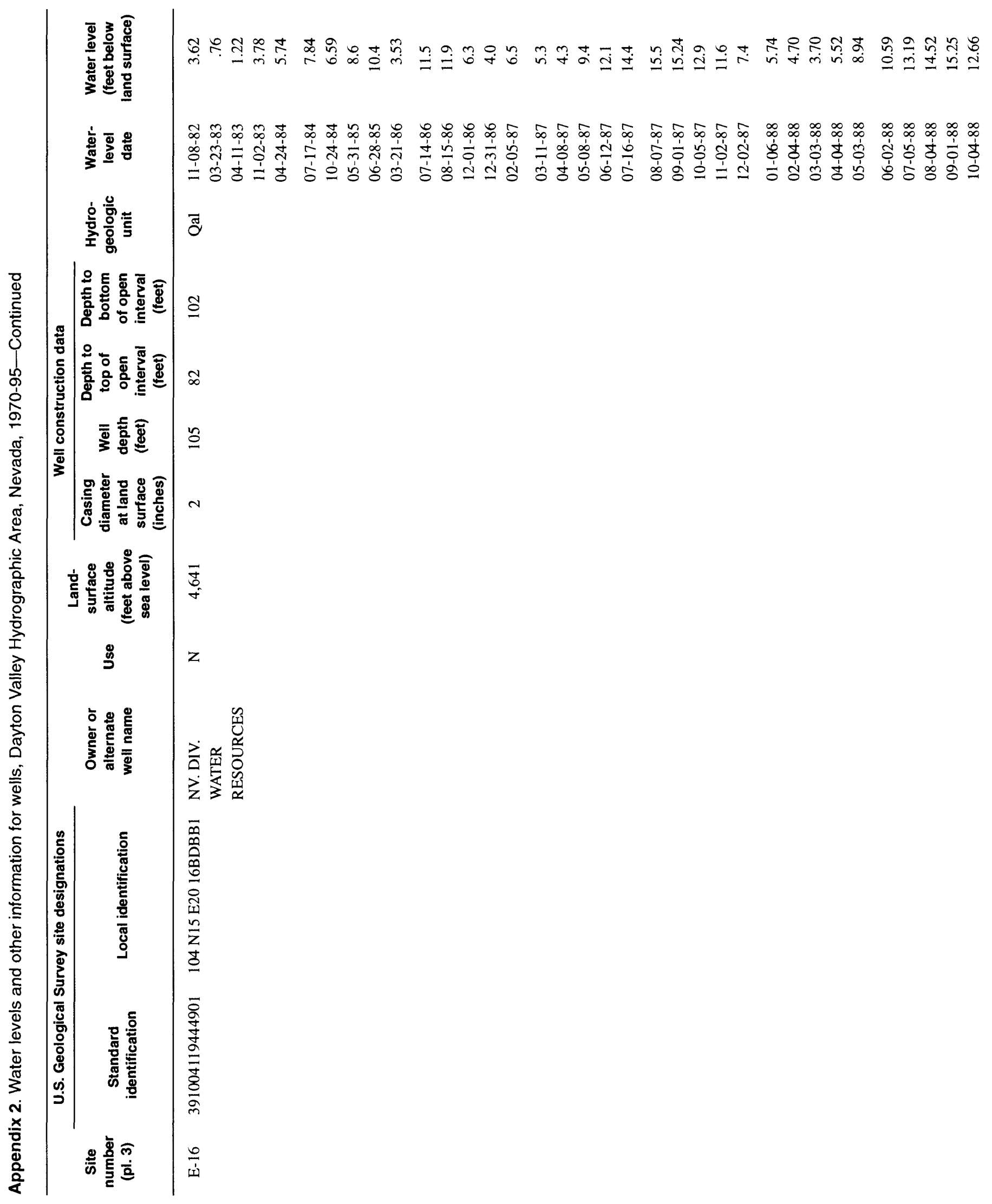




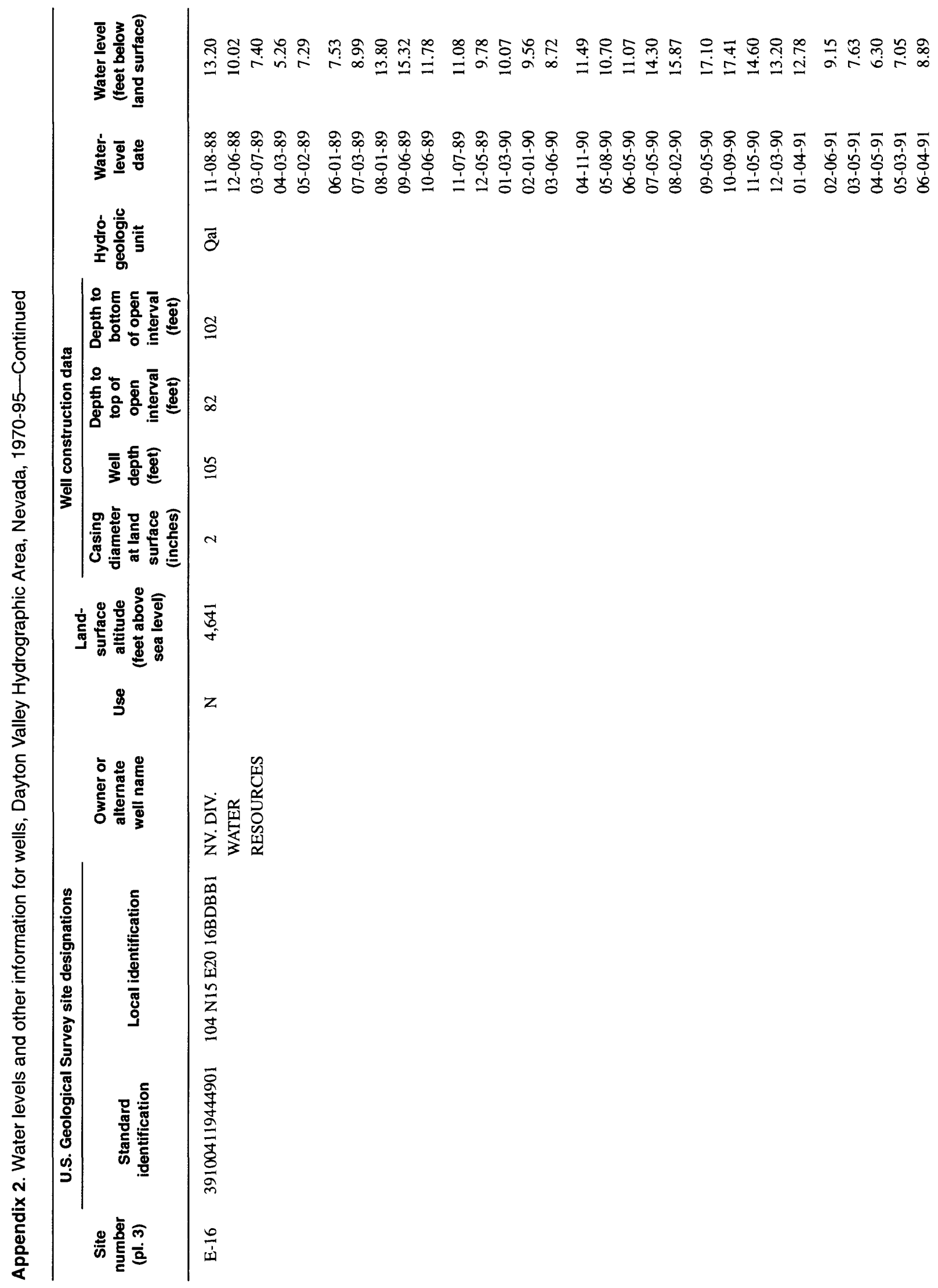




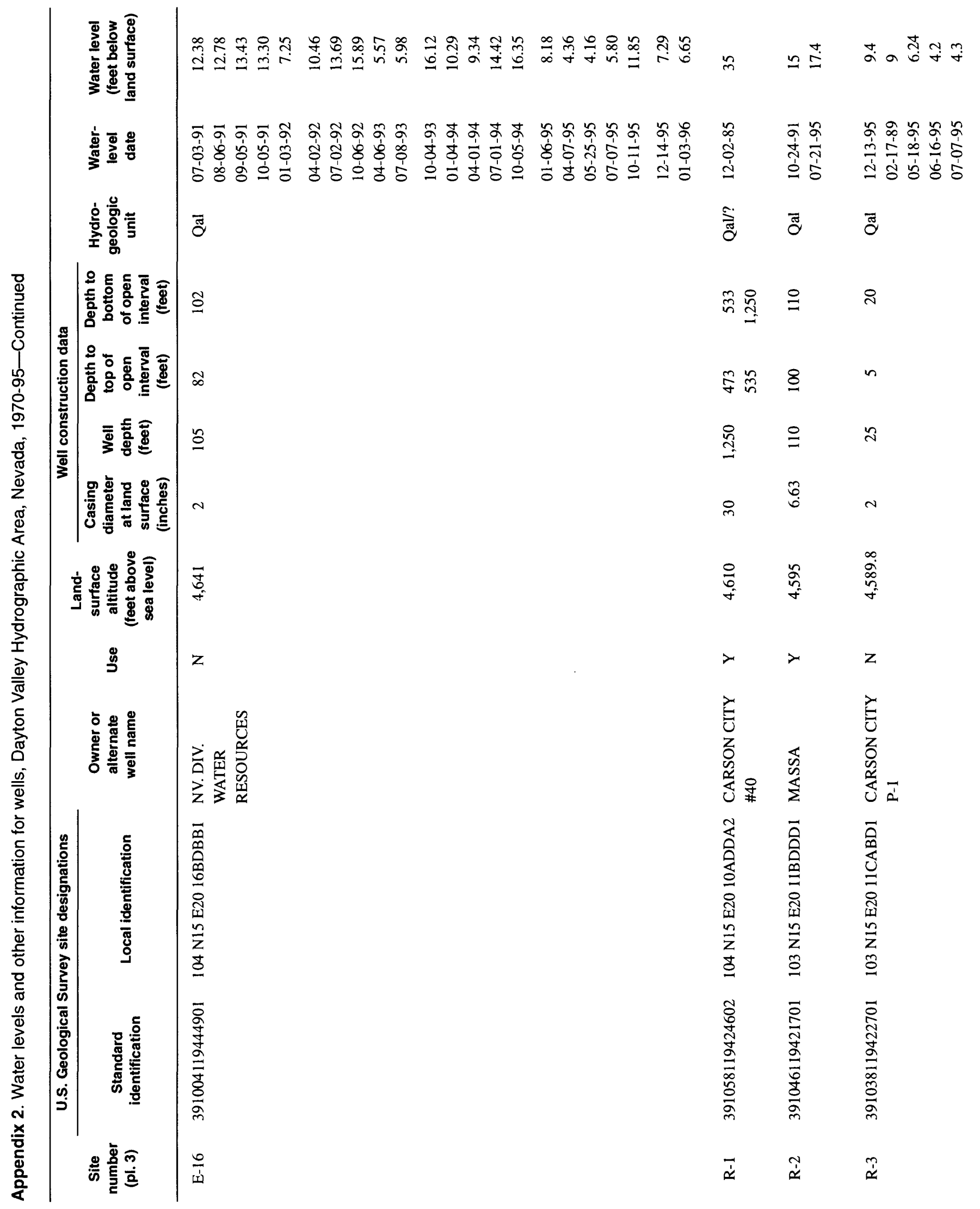




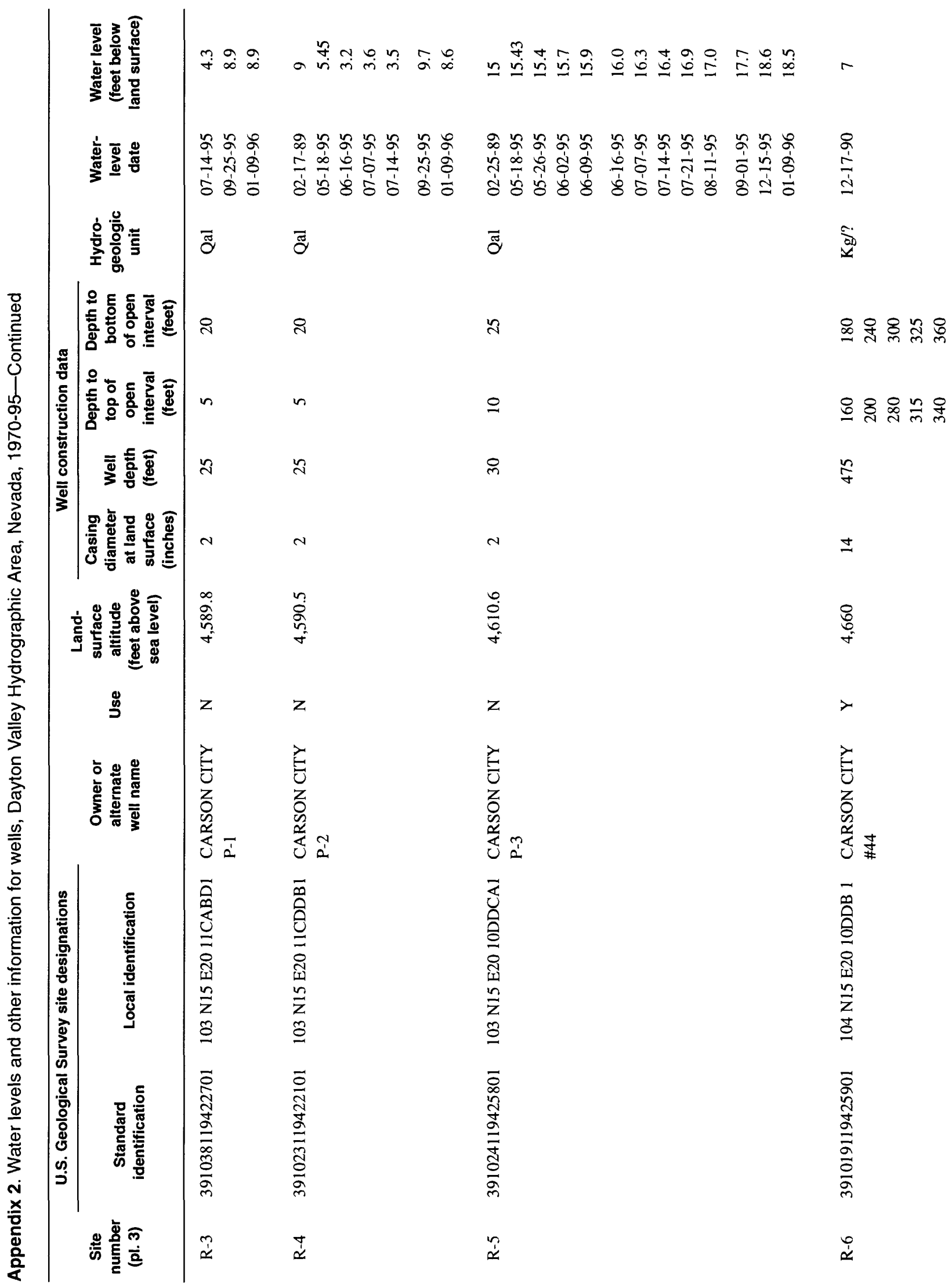




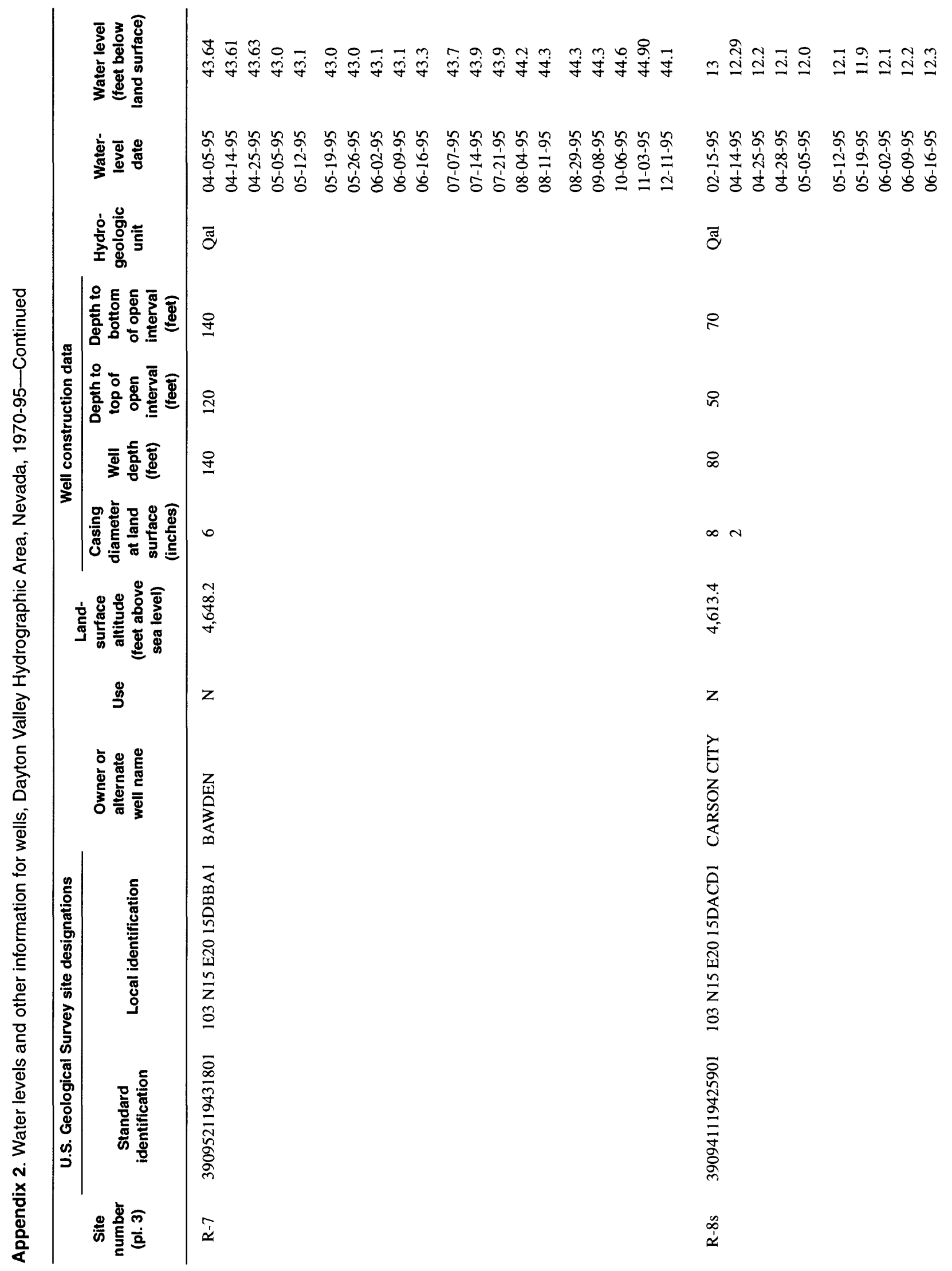




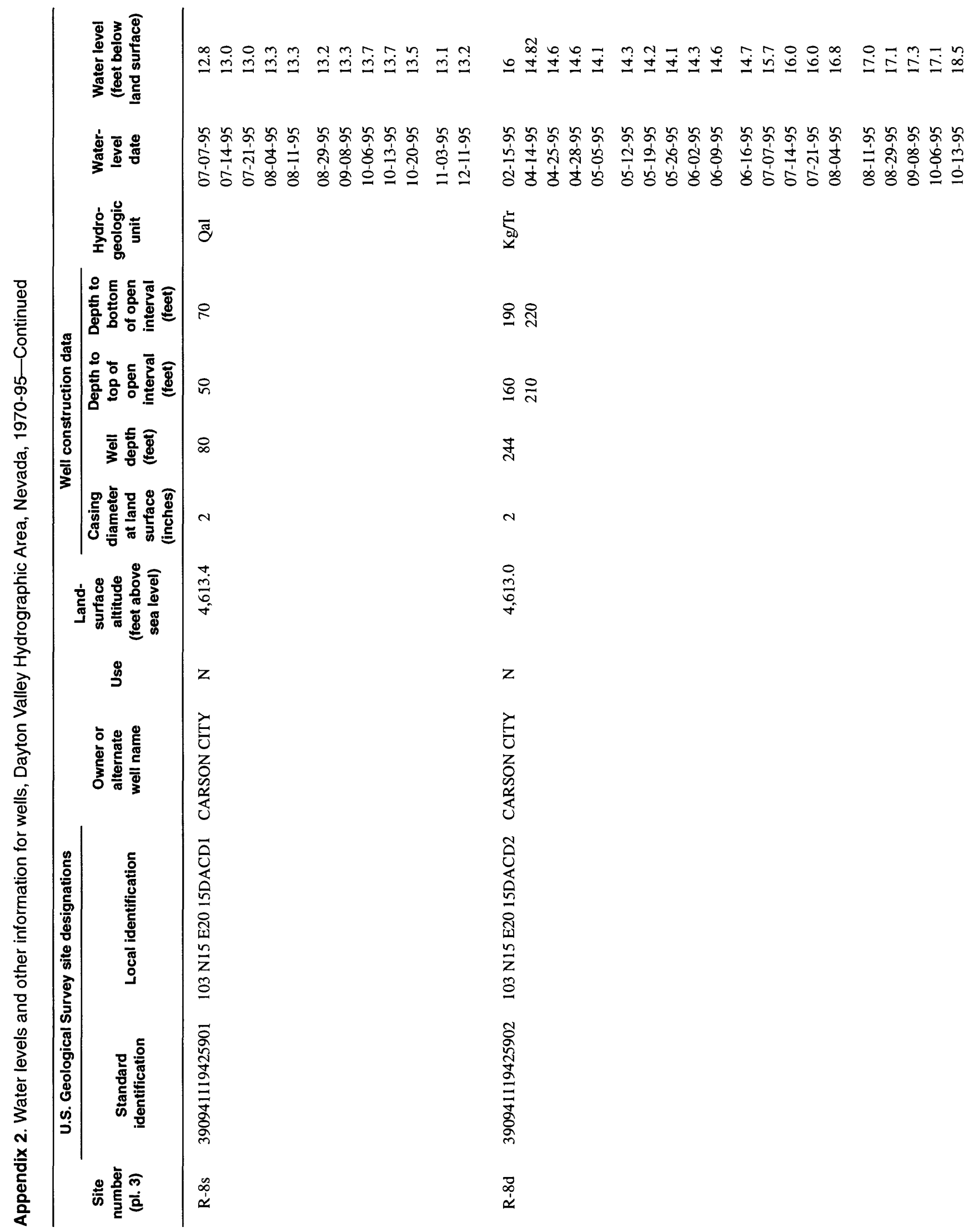




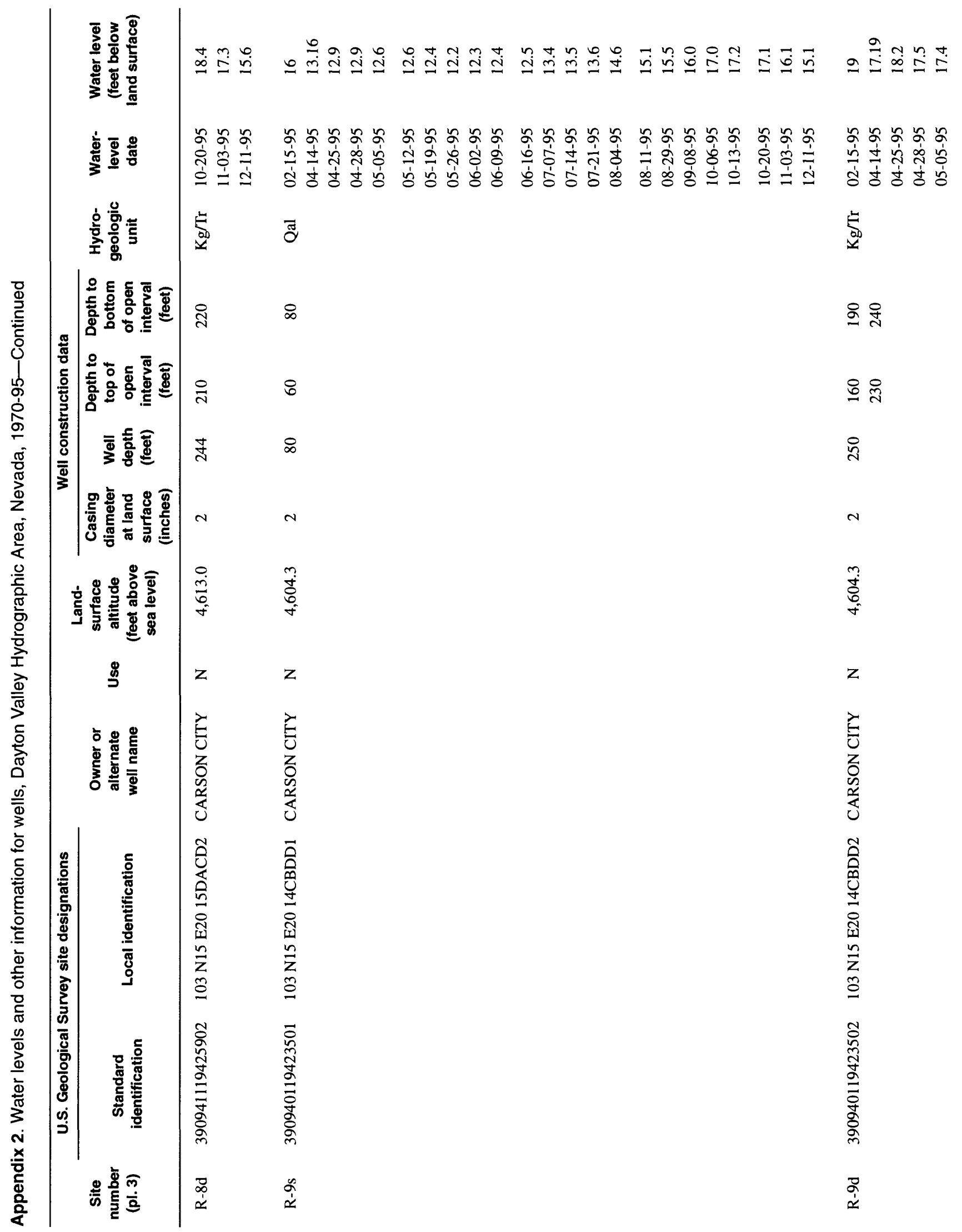




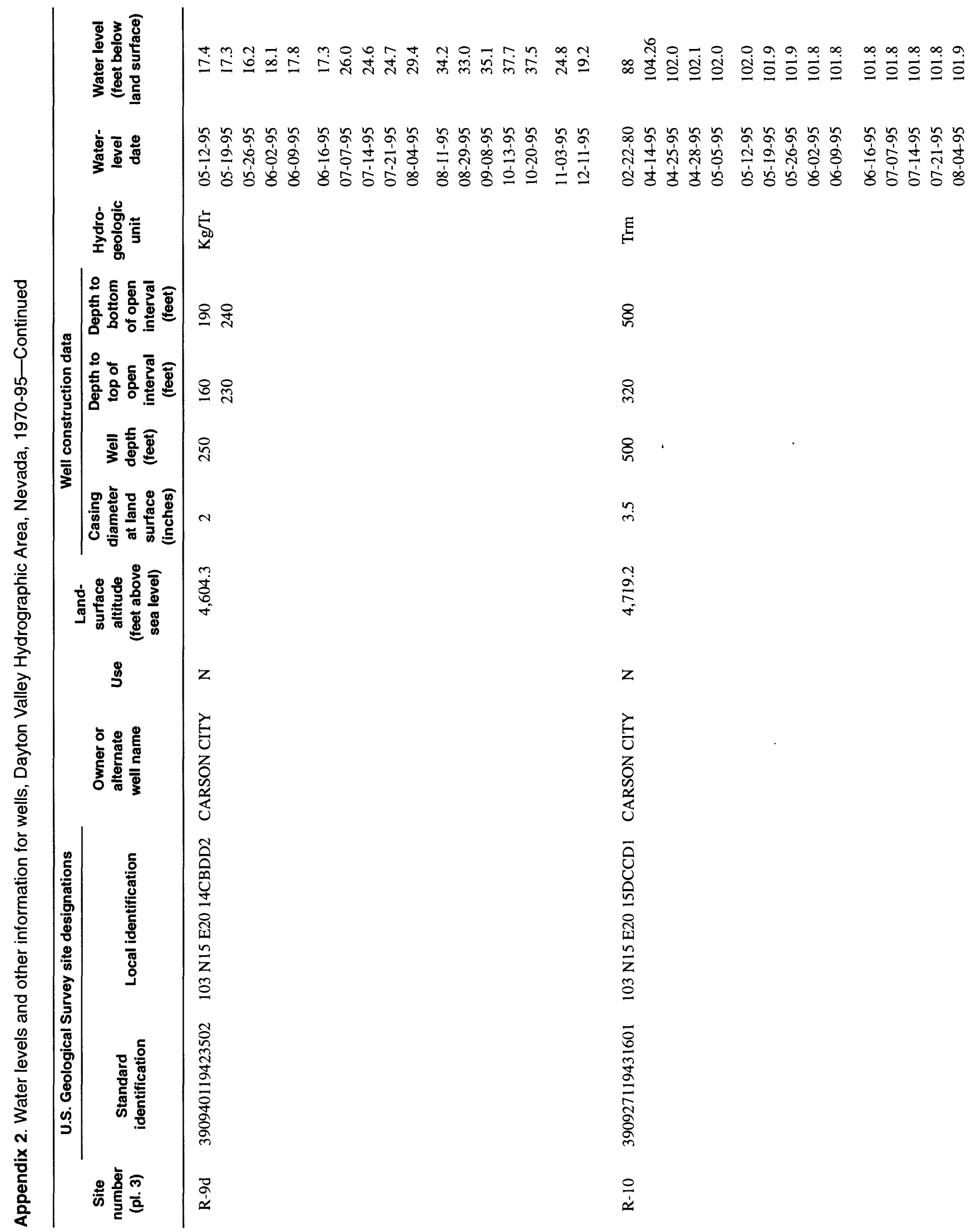




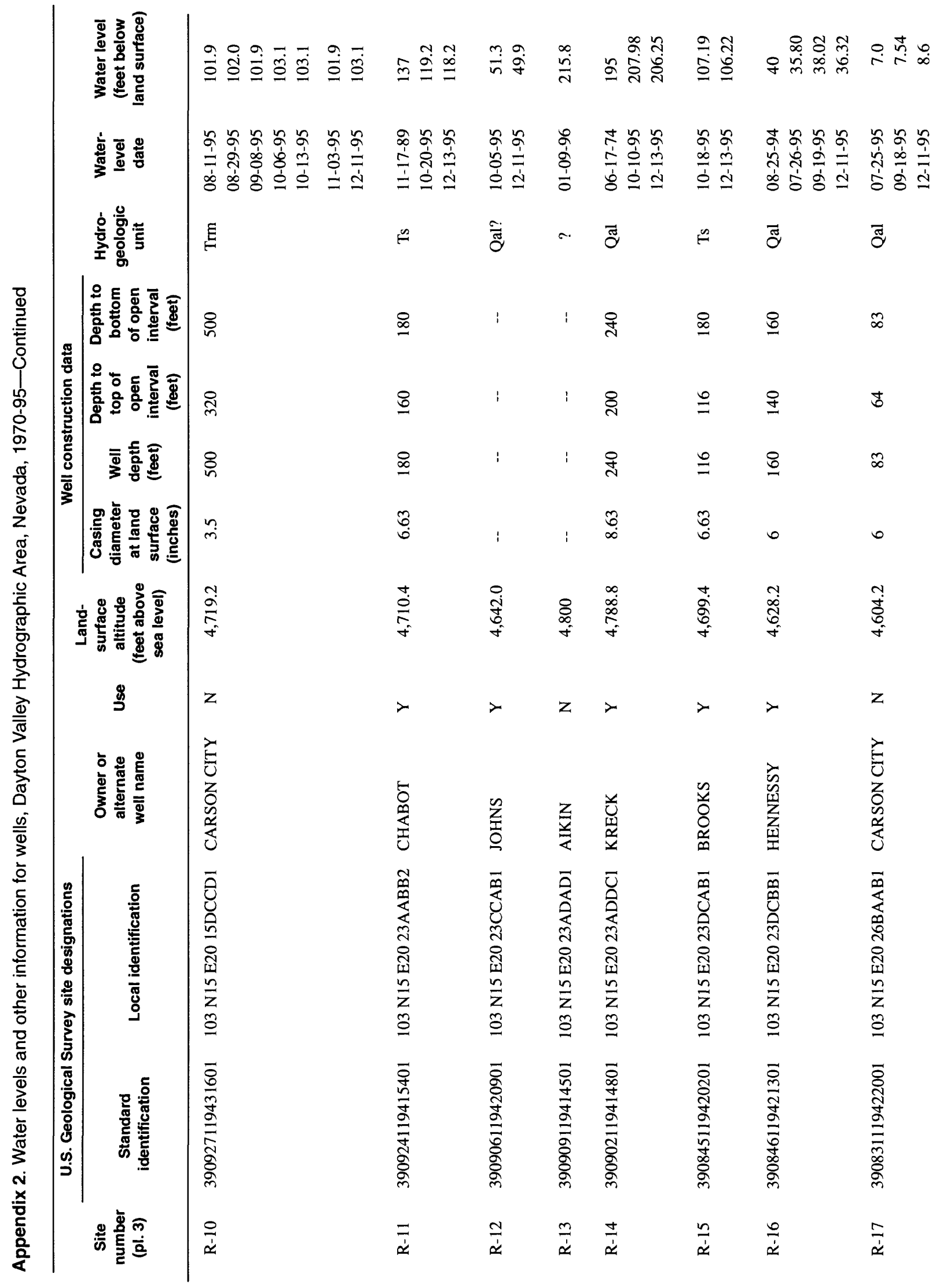




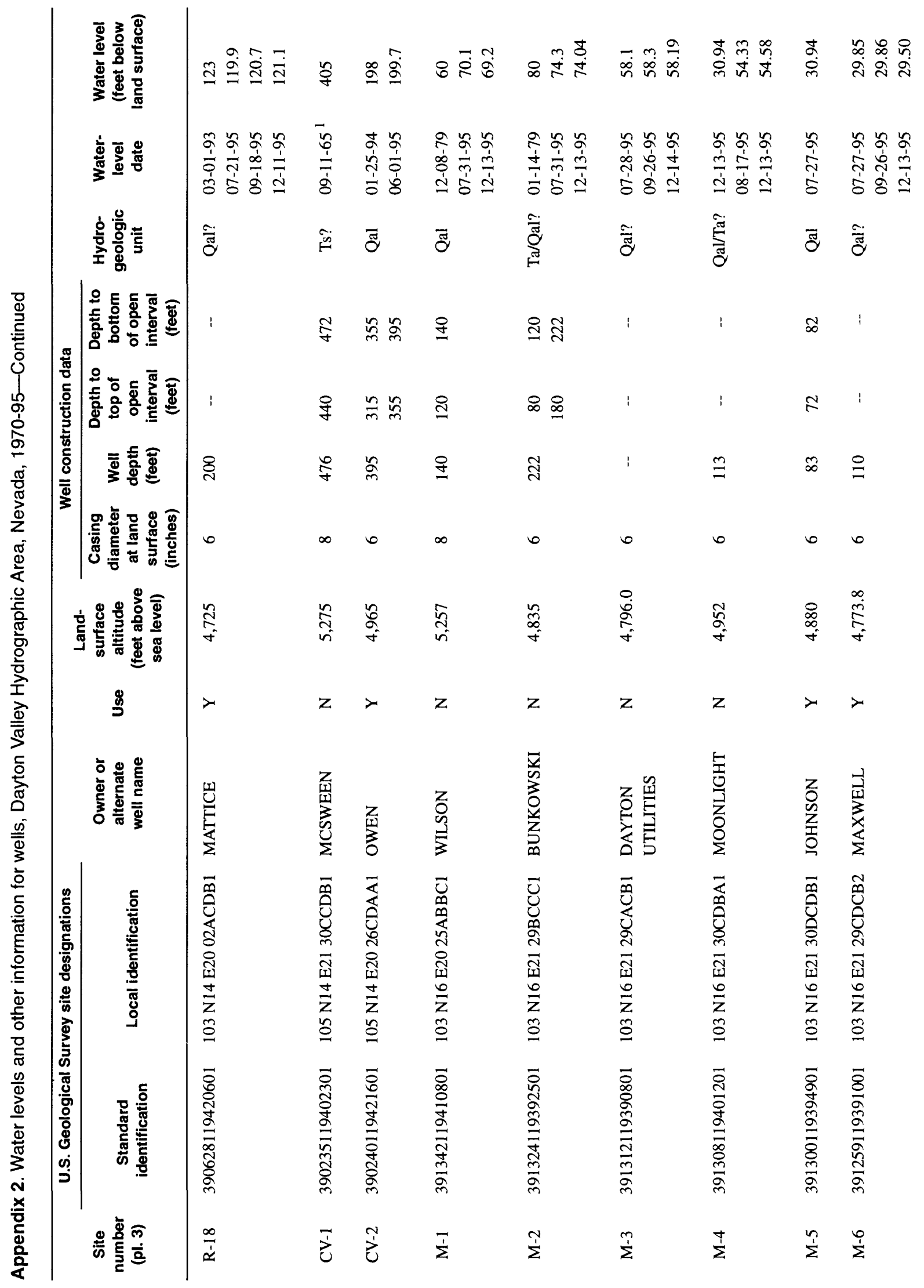




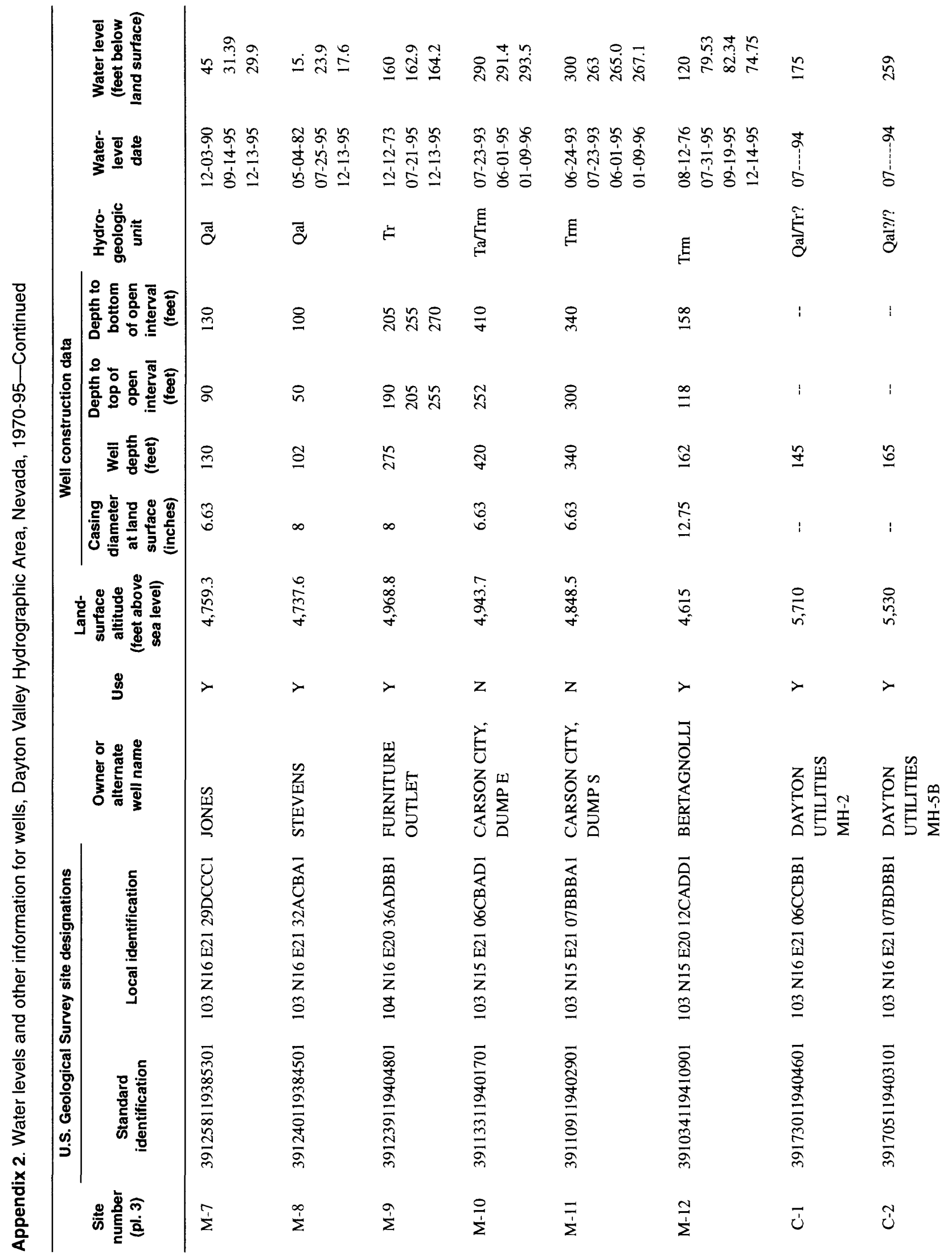




\begin{tabular}{|c|c|c|c|c|c|c|c|c|c|c|}
\hline & 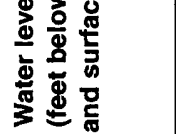 & $\supseteqq \stackrel{\dot{0}}{\dot{0}}$ & 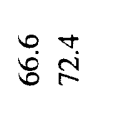 & תૈ: & 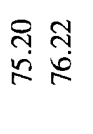 & 字高 & שू & $m$ & శి & 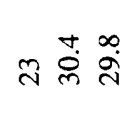 \\
\hline & 童产 & 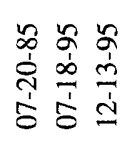 & 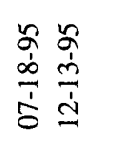 & 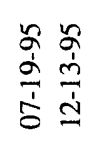 & 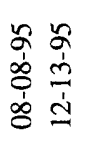 & 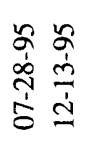 & 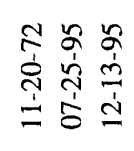 & 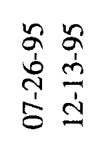 & 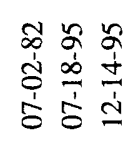 & 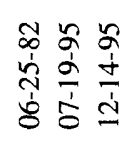 \\
\hline & 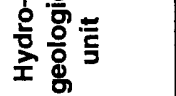 & $\bar{\delta}$ & $\ddot{4}$ & $\frac{\tilde{\partial}}{\partial}$ & f & $\tilde{\tilde{\alpha}}$ & $\overline{8}$ & $\overline{8}$ & f & $\approx$ \\
\hline & 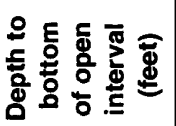 & $\stackrel{\infty}{\sim}$ & ' & : & : & : & $\stackrel{m}{9}$ & q & 용 & 円 \\
\hline 总 & 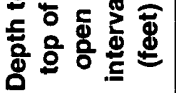 & $\stackrel{m}{-1}$ & ' & ' & ! & ' & $\infty$ & ฮิ & 88 & 8 \\
\hline 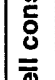 & 要言言 & $\underset{\text { స్ }}{ }$ & $\infty$ & $\stackrel{\circ}{\mathrm{N}}$ & $\frac{\infty}{m}$ & : & $\stackrel{\Xi}{g}$ & $\stackrel{8}{0}$ & 여 & $\stackrel{9}{9}$ \\
\hline & 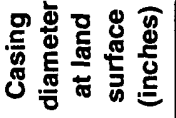 & 0 & 0 & : & ?. & $\infty$ & $\underset{\infty}{\infty}$ & $\underset{\infty}{\infty}$ & : & $\underset{\infty}{\mathscr{8}}$ \\
\hline & 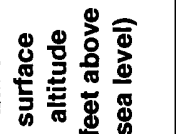 & ڤ్ & $\frac{\dot{0}}{n}$ & 辛 & 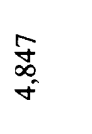 & $\begin{array}{l}\stackrel{0}{0} \\
\dot{0} \\
\stackrel{0}{+} \\
\dot{f}\end{array}$ & $\begin{array}{l}a \\
\text { हे } \\
\dot{\sigma}\end{array}$ & \begin{tabular}{l}
$\approx$ \\
\multirow{n}{*}{} \\
$\forall$
\end{tabular} & $\begin{array}{l}\stackrel{8}{0} \\
\stackrel{0}{+}\end{array}$ & 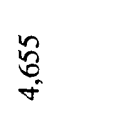 \\
\hline & $\stackrel{\mathscr{D}}{2}$ & z & z & z & z & z & z & $z$ & $\succ$ & 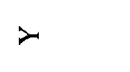 \\
\hline & 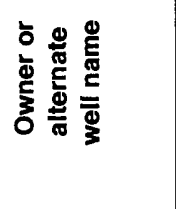 & 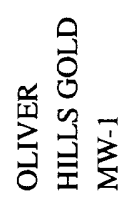 & 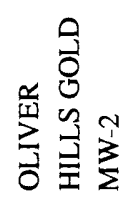 & 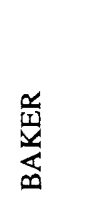 & 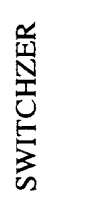 & - & 站 & $\begin{array}{l}z \\
0 \\
3 \\
3\end{array}$ & 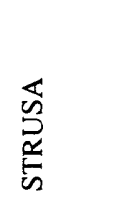 & 离 \\
\hline 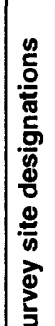 & 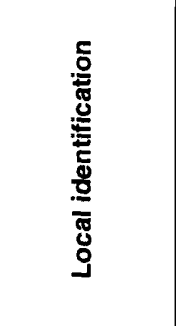 & 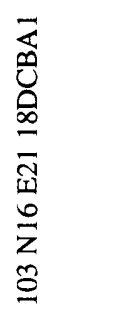 & 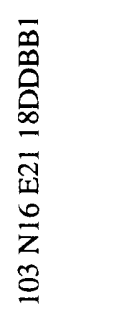 & 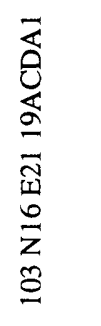 & 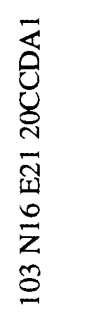 & 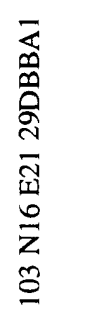 & 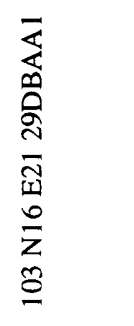 & 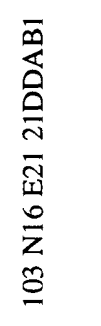 & 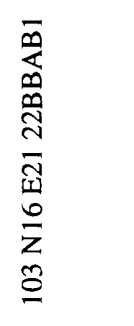 & 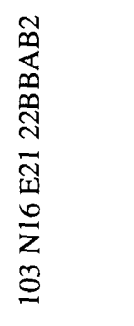 \\
\hline 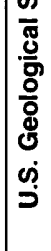 & 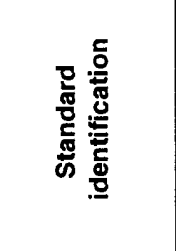 & 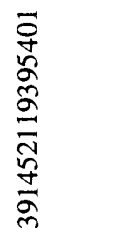 & 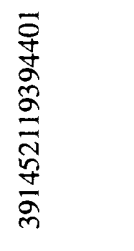 & $\begin{array}{l}\overline{\vec{\sigma}} \\
\frac{\sigma}{\sigma} \\
\frac{\sigma}{\sigma} \\
\frac{\sigma}{\sigma} \\
\frac{\sigma}{\sigma}\end{array}$ & $\begin{array}{l}\overline{\bar{\sigma}} \\
\frac{\sigma}{\sigma} \\
\frac{\sigma}{\bar{\sigma}} \\
\frac{\tilde{m}}{\sigma}\end{array}$ & 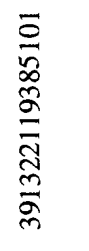 & 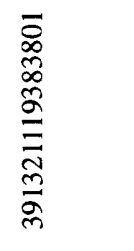 & 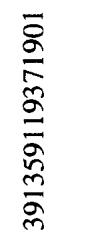 & 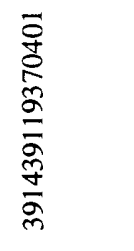 & 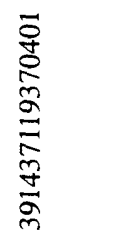 \\
\hline & 产 & $\hat{U}$ & U & $\tilde{u}$ & نُ & ن́ & $u^{\infty}$ & نे & ن & $\bar{u}$ \\
\hline
\end{tabular}




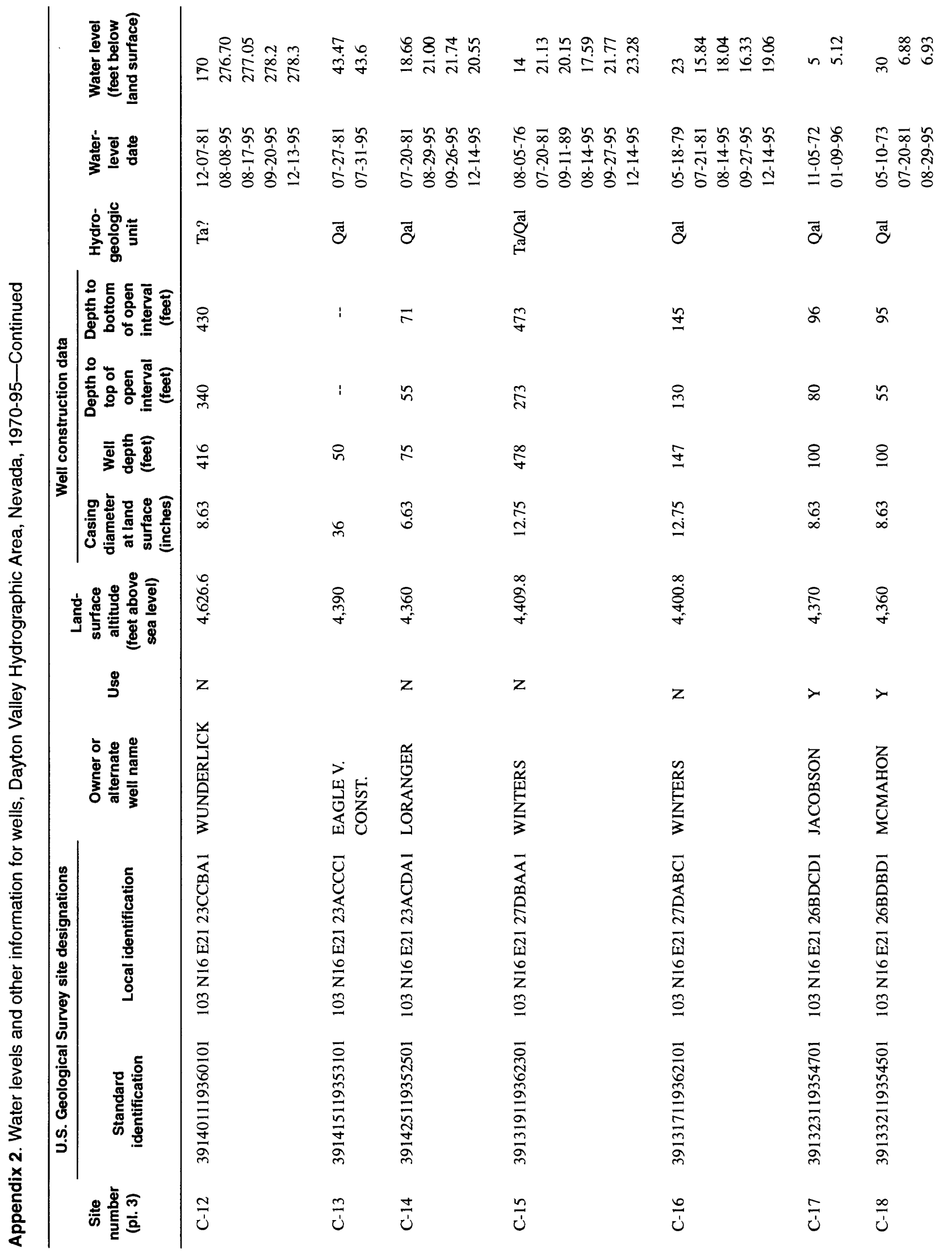




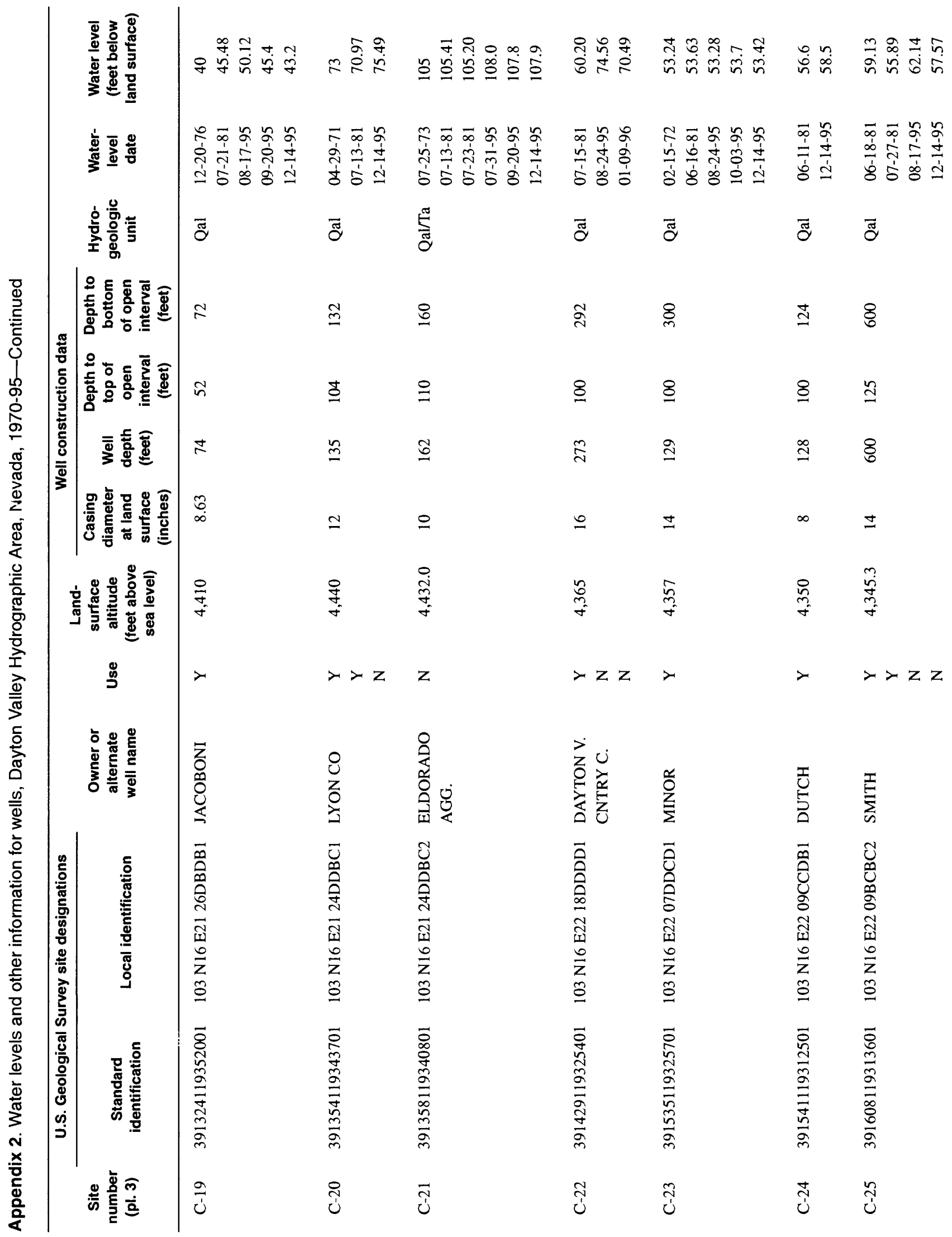




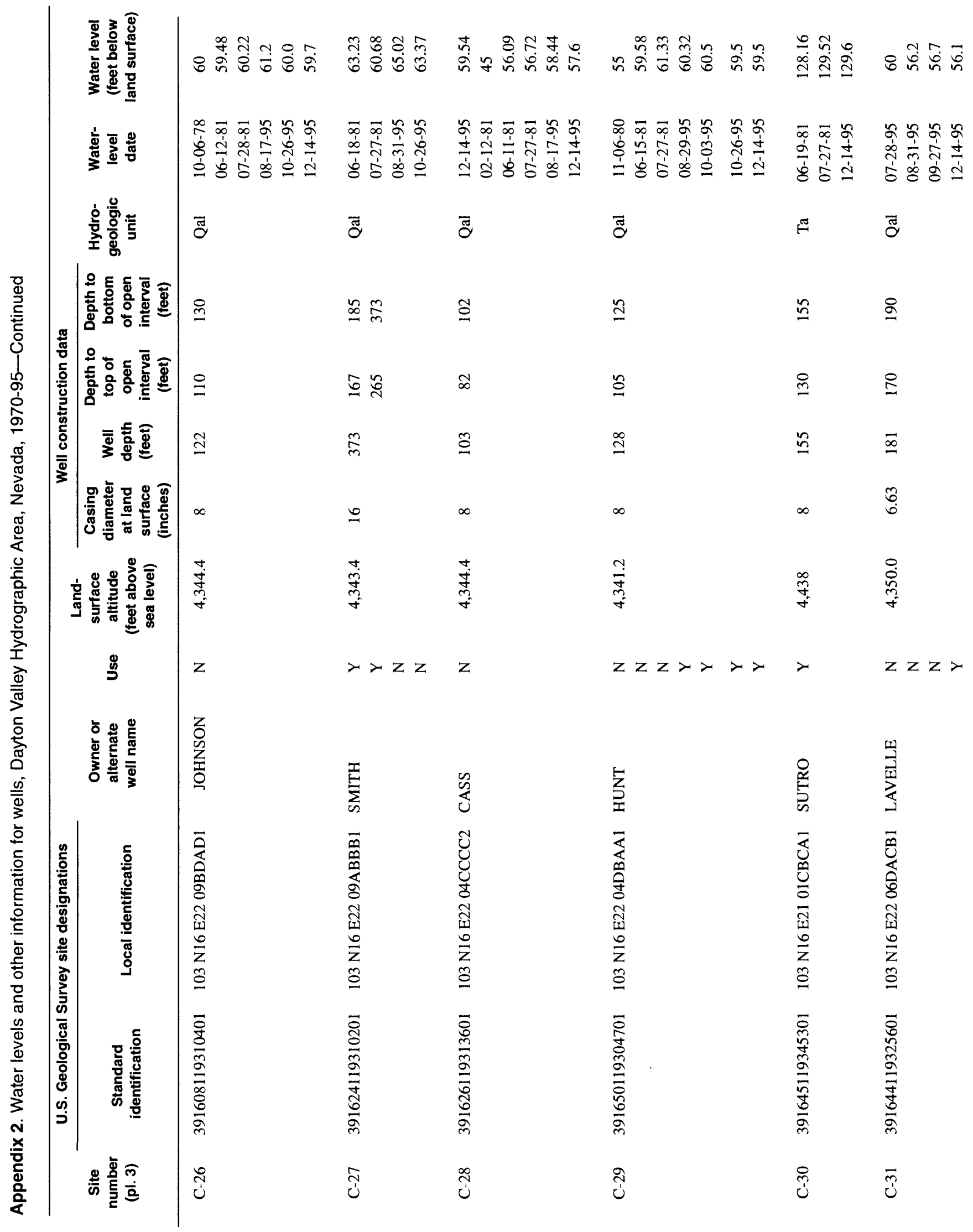




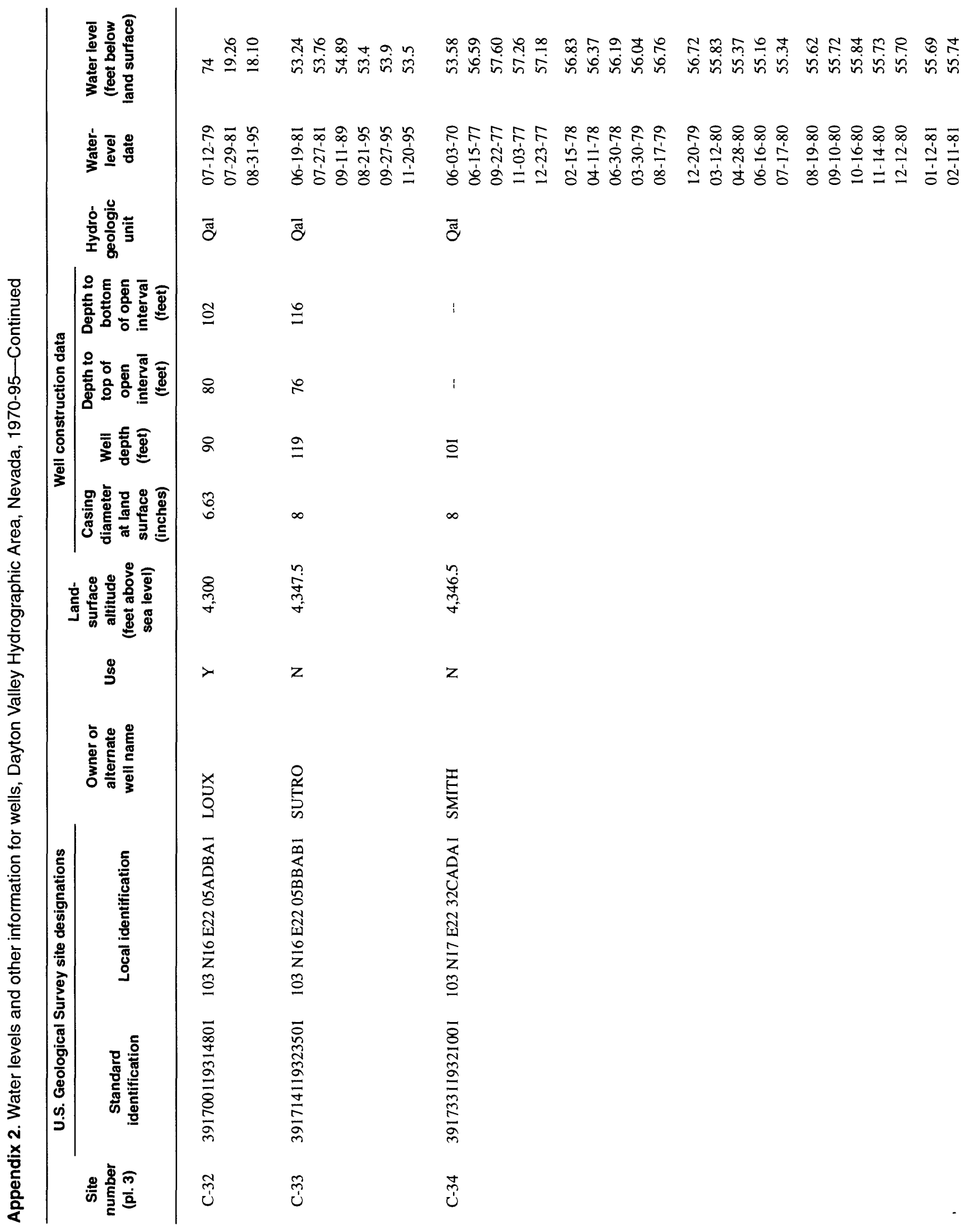




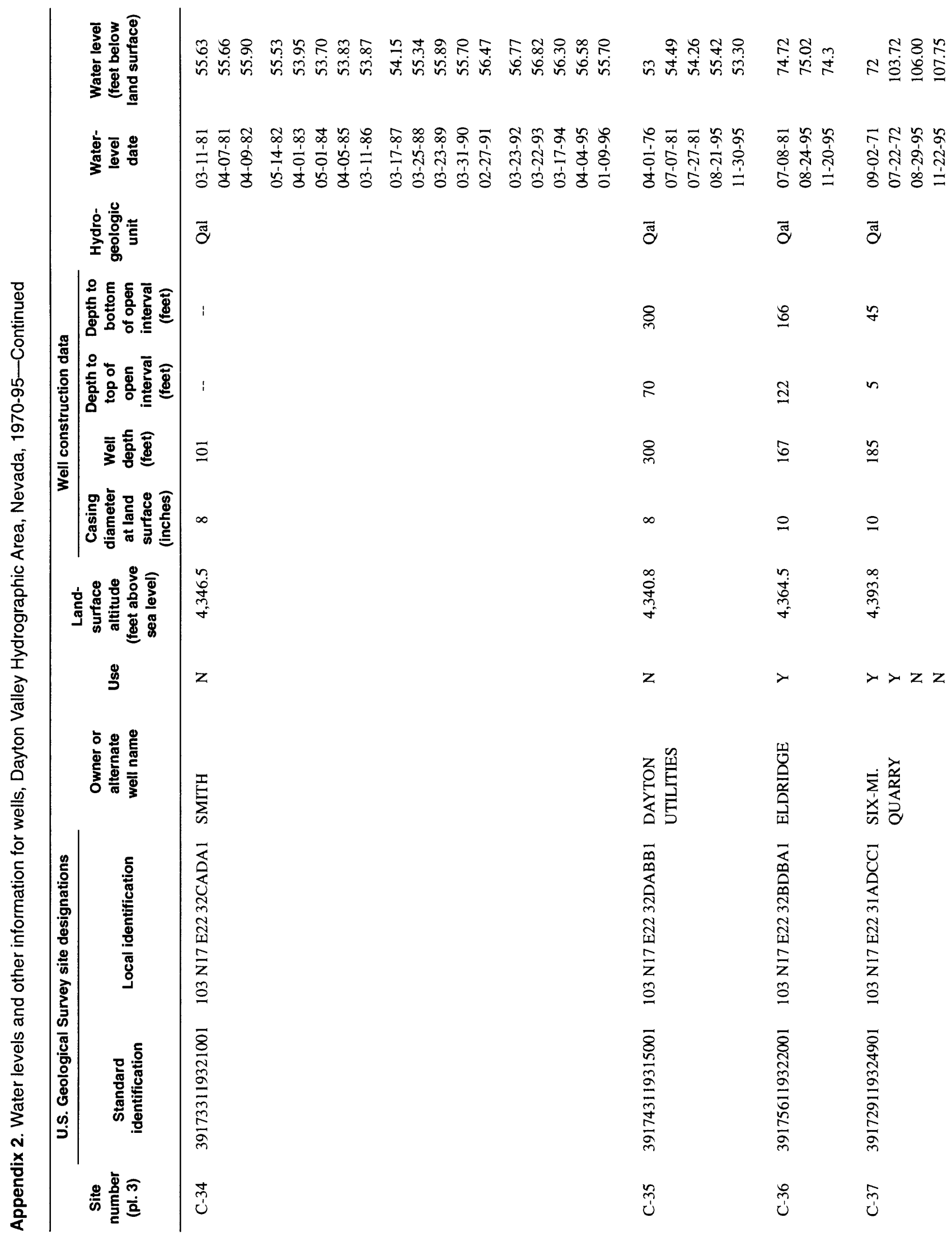




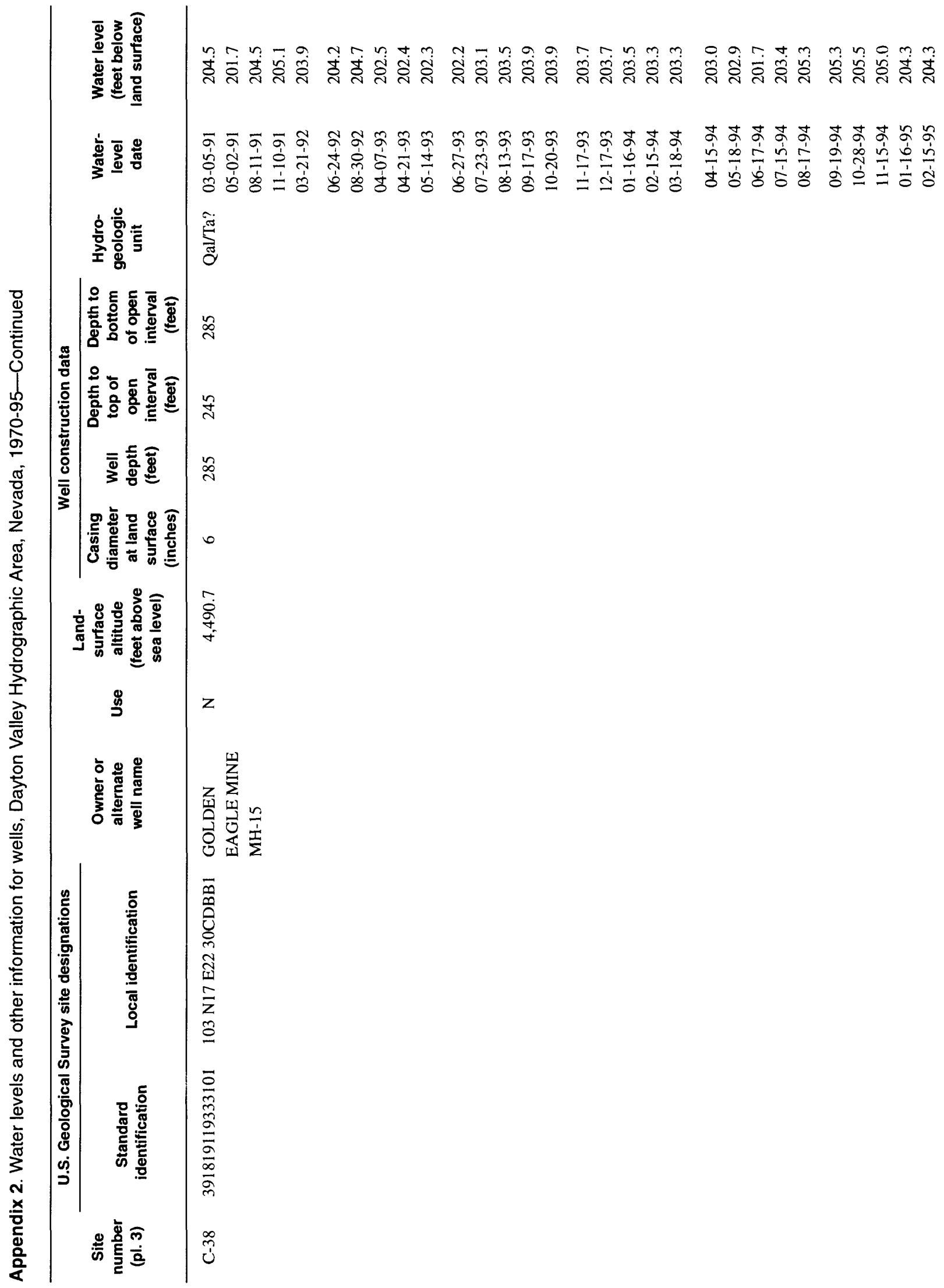




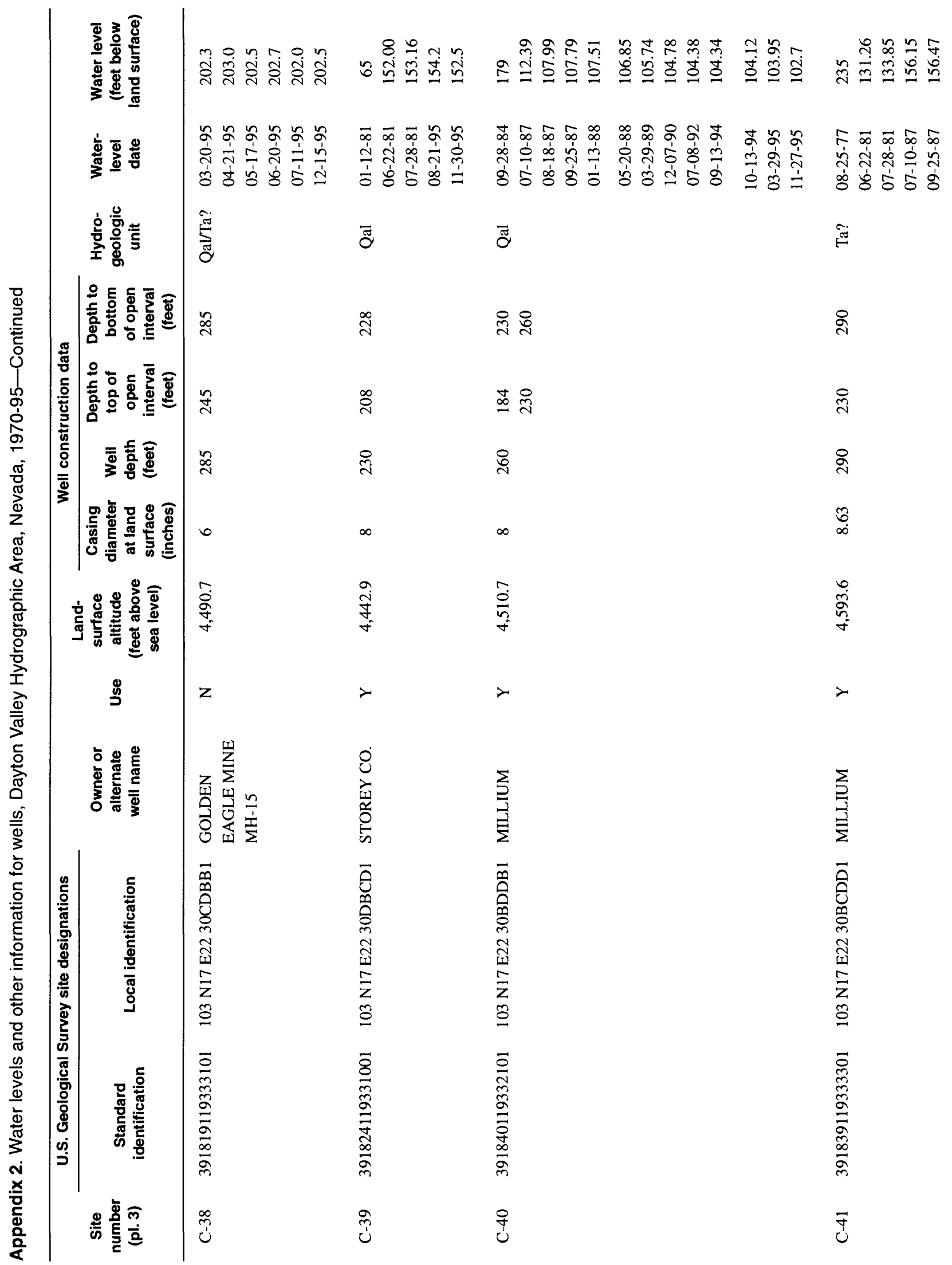




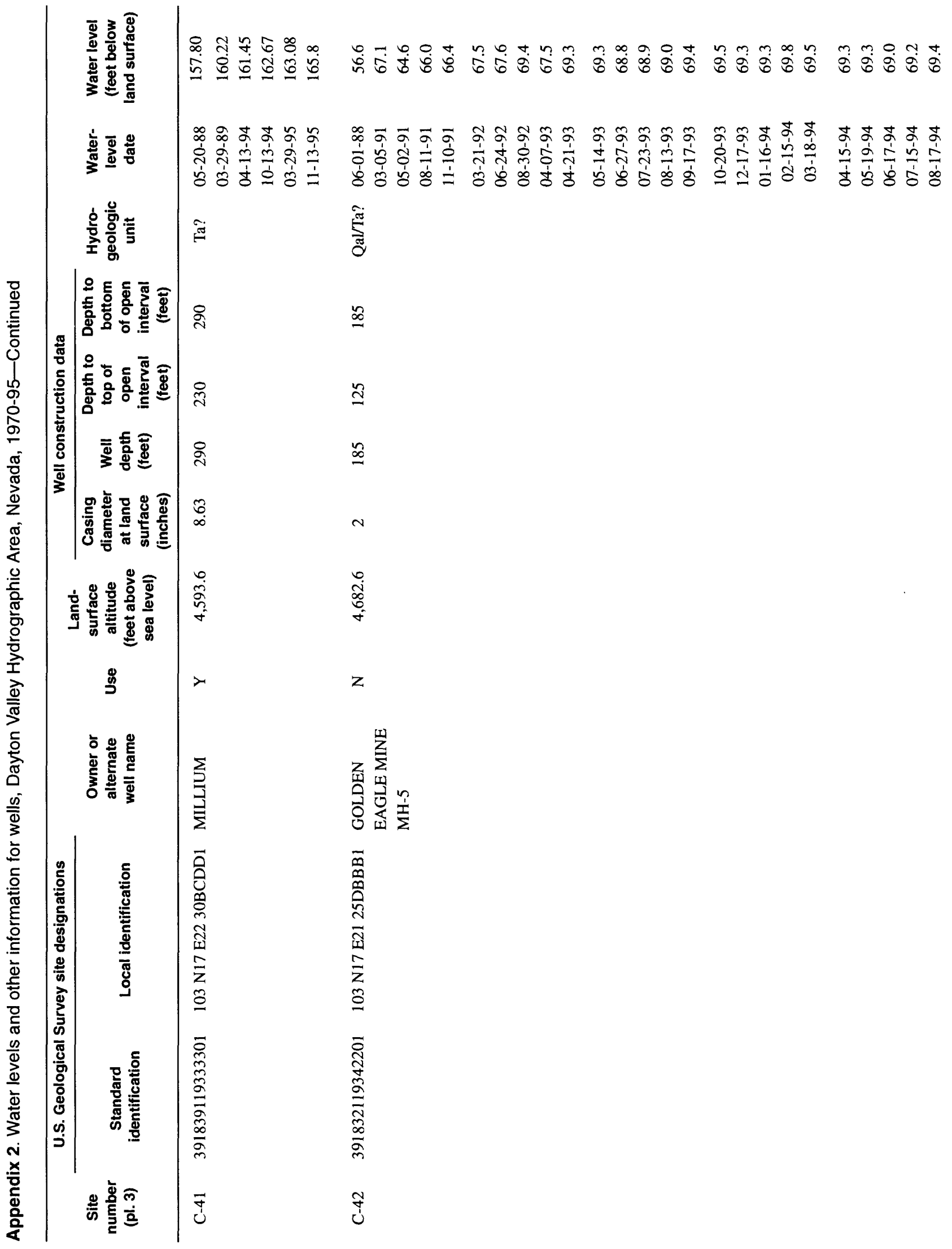




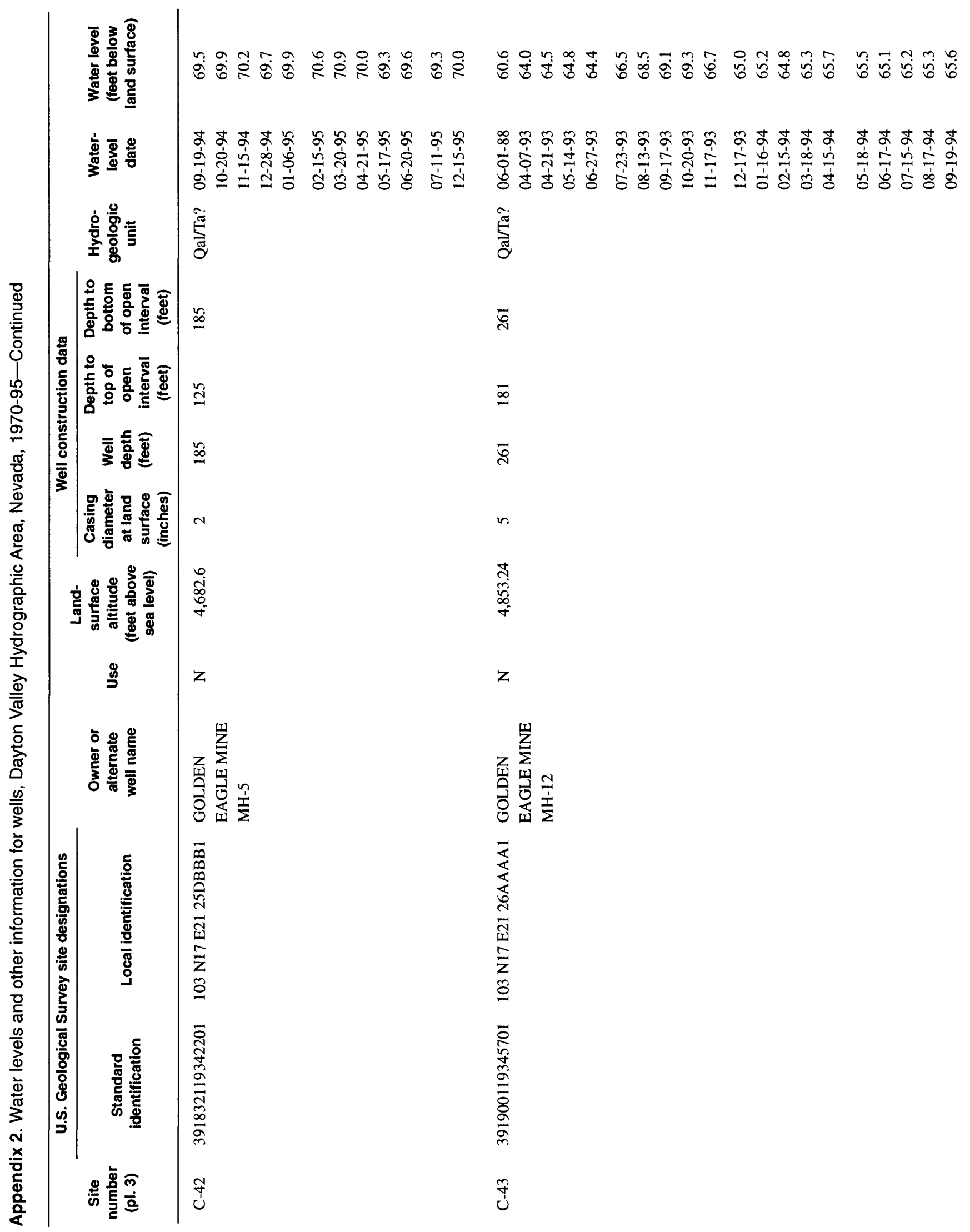




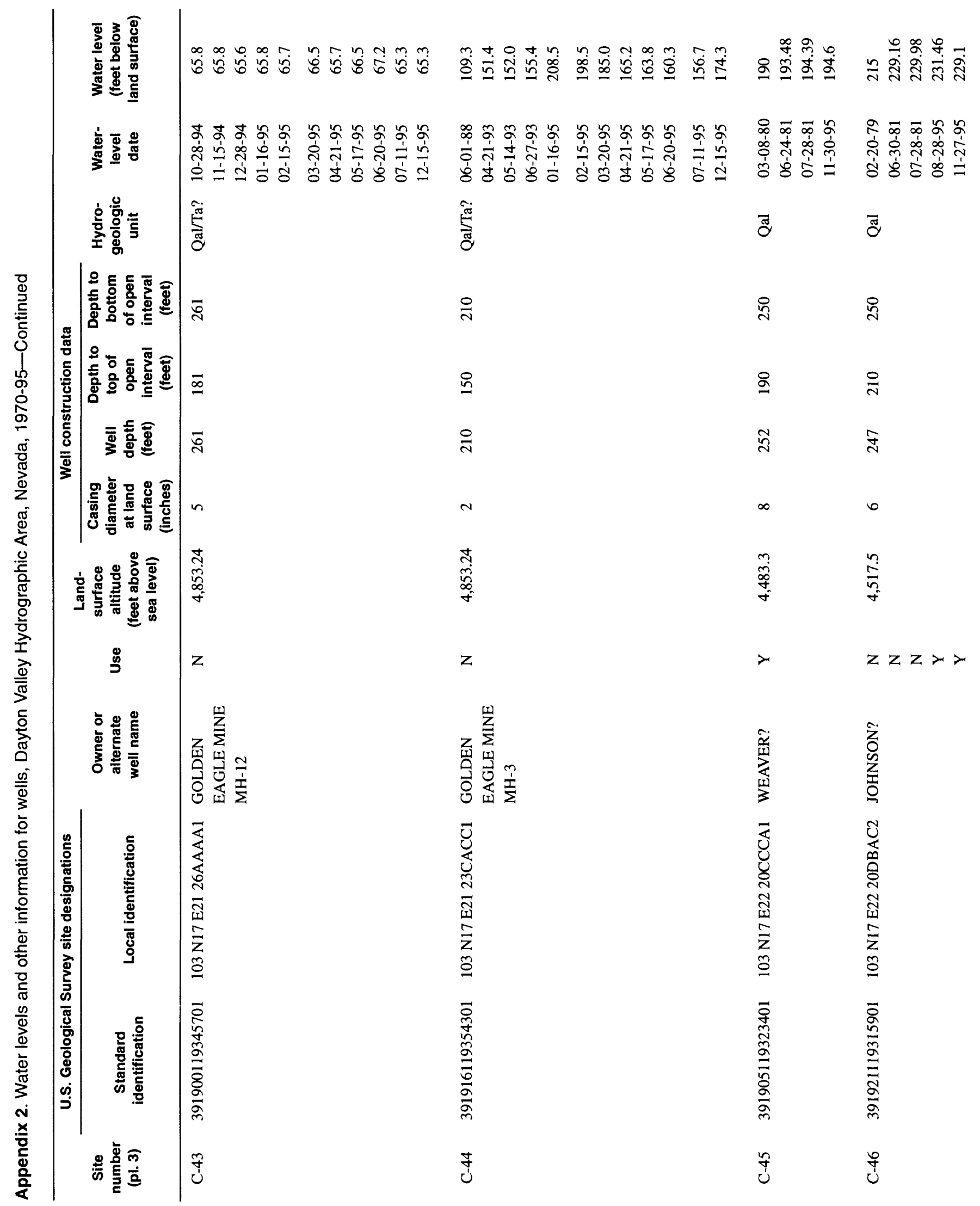




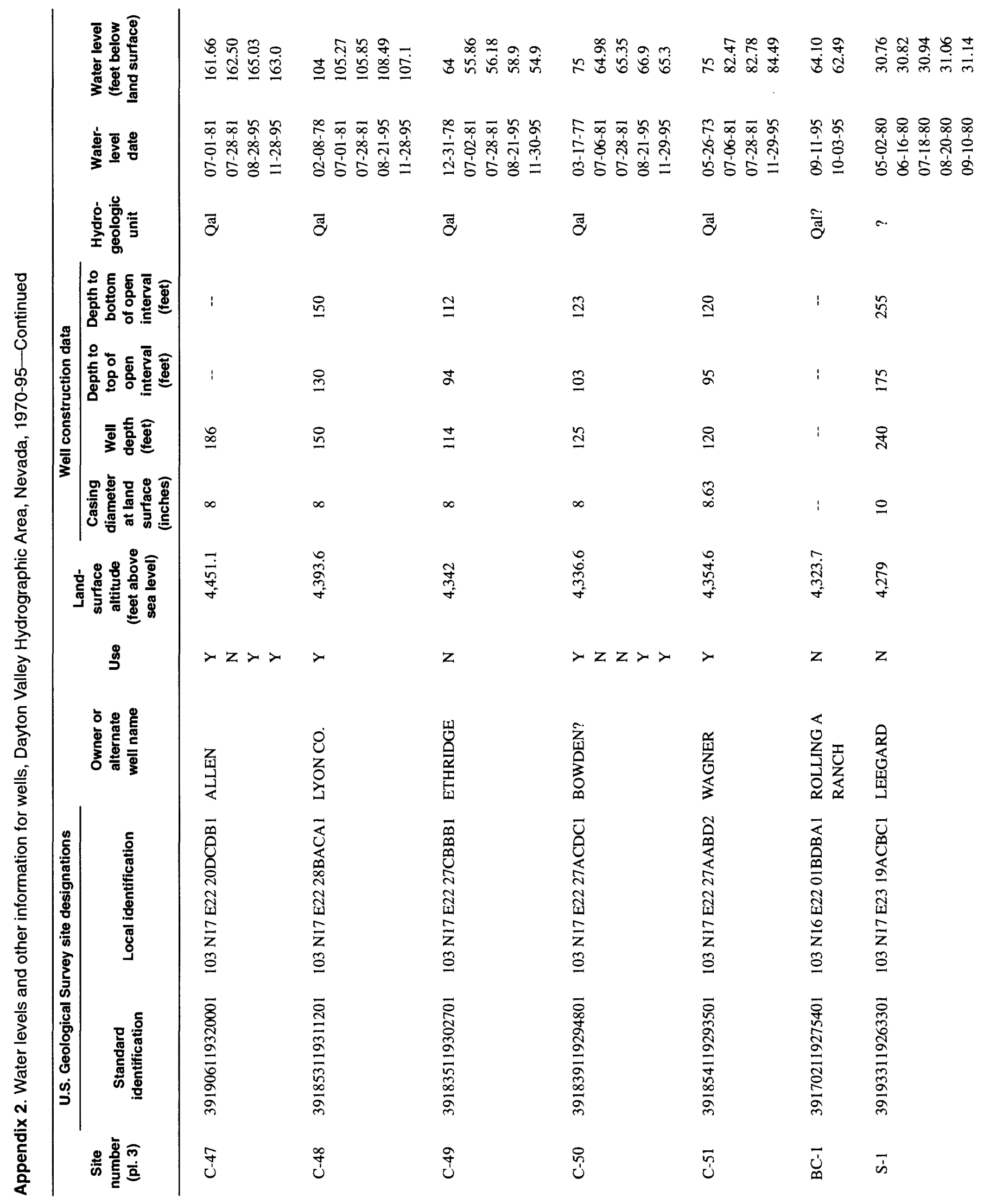




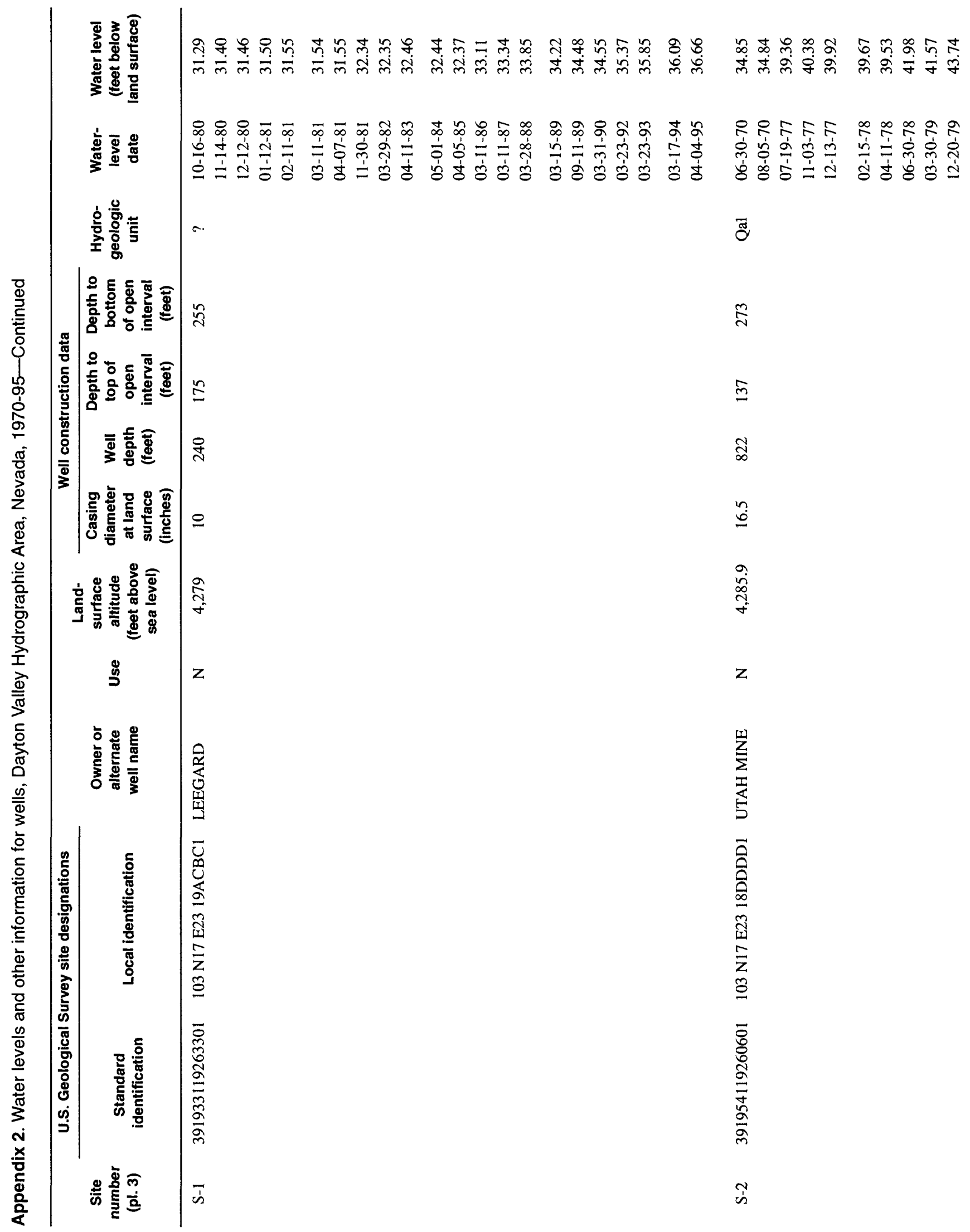




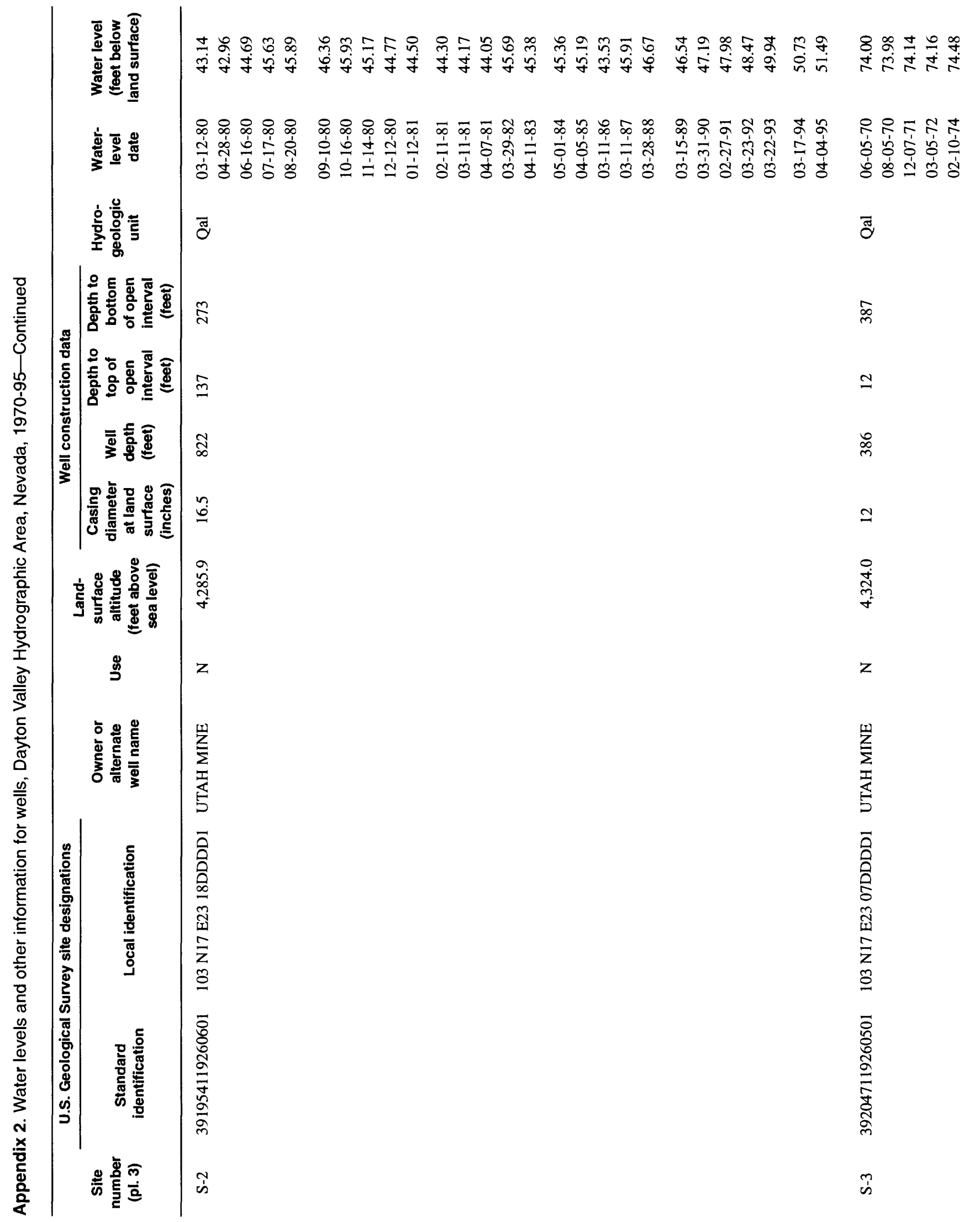




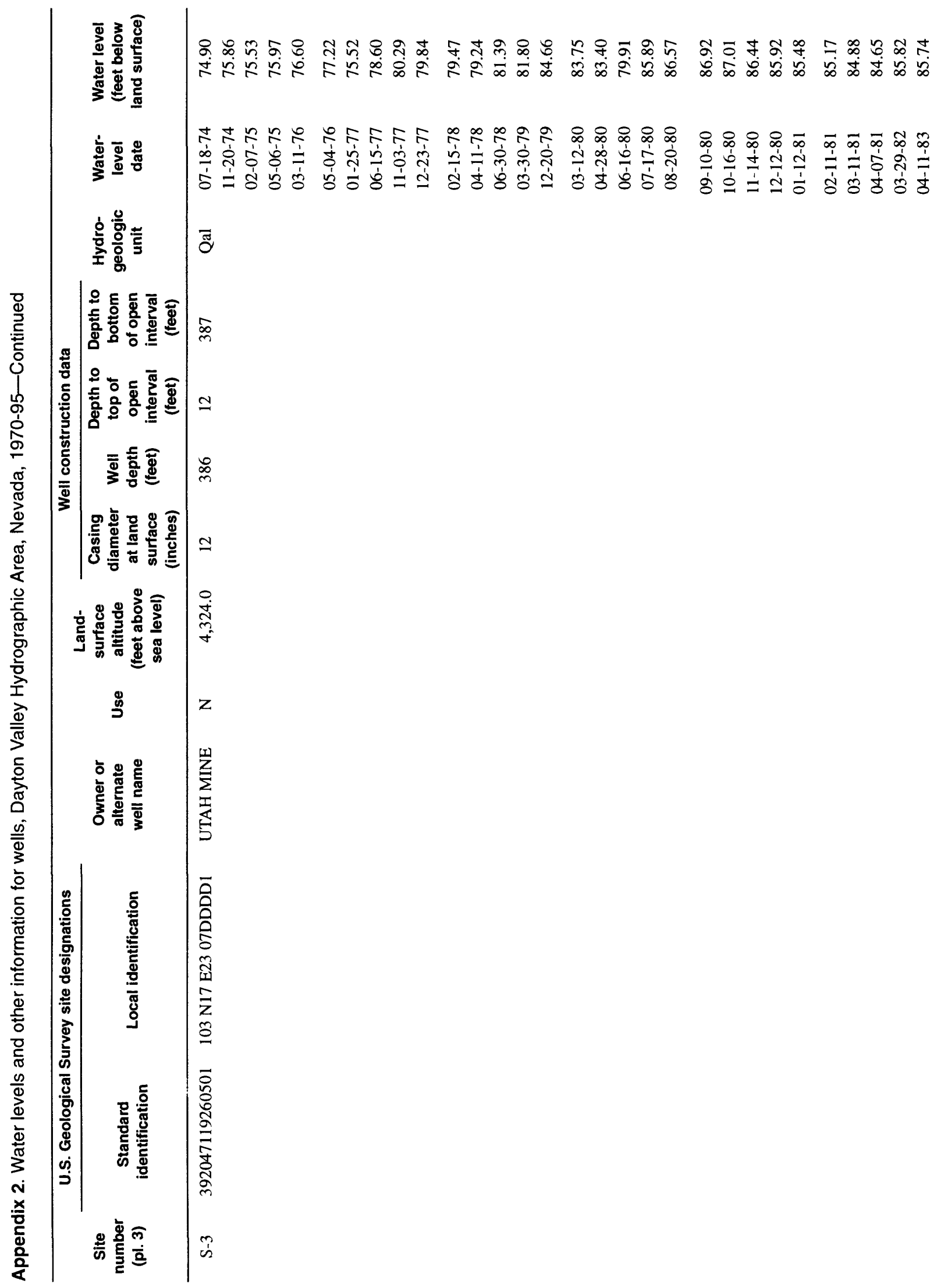




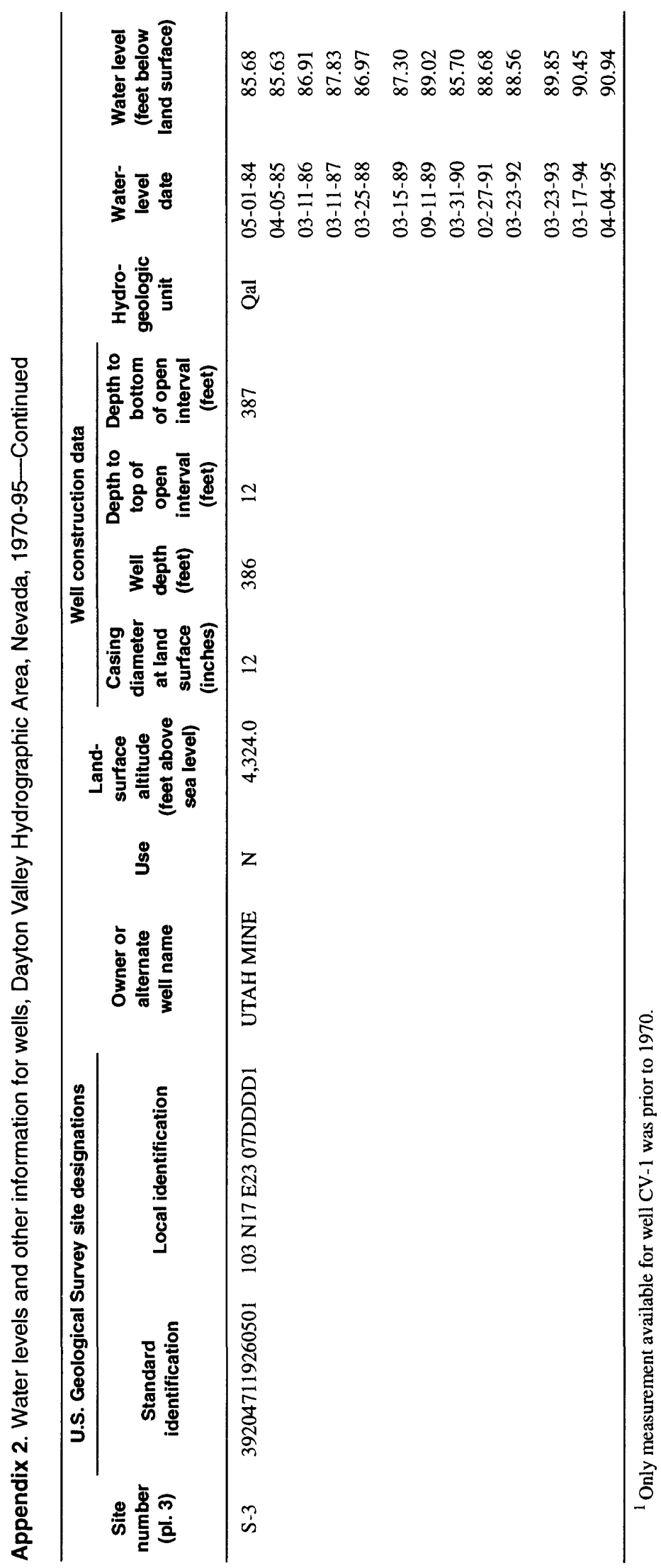

